UNIVERSIDADE DE SÃO PAULO

FACULDADE DE FILOSOFIA, LETRAS E CIÊNCIAS HUMANAS

DEPARTAMENTO DE LETRAS ORIENTAIS

PROGRAMA DE PÓS-GRADUAÇÃO EM LÍNGUA, LITERATURA,

E CULTURA JAPONESA

\title{
MIGRAÇÃO REPETITIVA ENTRE O BRASIL E O JAPÃO
}

\section{Lina Kojima}

Dissertação apresentada ao Programa de Pós-Graduação em Língua, Literatura

e Cultura Japonesa, da Faculdade de Filosofia, Letras e Ciências Humanas, da Universidade de São Paulo, para obtenção do título de Mestre em Letras.

Orientador: Prof. Dr. Masato Ninomiya

São Paulo

2009

FOLHA DE APROVAÇÃO 


\section{Lina Kojima}

Migração Repetitiva entre o Brasil e o Japão

Dissertação apresentada ao Programa de Pós-Graduação em Língua, Literatura

e Cultura Japonesa, da Faculdade de Filosofia, Letras e Ciências Humanas, da Universidade de São Paulo, para obtenção do título de Mestre em Letras.

Aprovado em:

Banca Examinadora

Prof. Dr.

Instituição:

Assinatura

Prof. Dr.

Instituição: Assinatura

Prof. Dr.

Instituição: Assinatura

Prof. Dr.

Instituição: Assinatura 


\section{RESUMO}

KOJIMA, Lina. Migração Repetitiva entre o Brasil e o Japão. 2009. 134 f. Dissertação (Mestrado) - Faculdade de Filosofia, Letras e Ciências Humanas, Universidade de São Paulo, São Paulo, 2009.

A ideia desta dissertação nasceu da pesquisa intitulada $O$ Shuttle Migration dos brasileiros residentes no Japão sobre os fenômenos decasségui e o chamado Shuttle Migration. Desde o início do movimento decasségui, emigração dos brasileiros para o Japão, já se passaram mais de 20 anos. $\mathrm{O}$ referido movimento tem mostrado diversas mudanças, sendo uma delas o aparecimento de Shuttle Migration, doravante denominado como Migração Repetitiva.

A Migração Repetitiva refere-se a "pessoas migrantes que vão e retornam entre locais de residência, no caso, situados em países diversos, repetindo muitas vezes esse "vai e volta"". Muitos dos trabalhadores brasileiros no Japão tentam regressar para o Brasil, porém, frequentemente não conseguem readaptar-se e partem novamente. Neste trabalho, tentamos entender os motivos dessas idas e voltas através de contexto histórico-estrutural dos dois países.

Palavras-chave: Migração Repetitiva, Decasségui, Imigração Japonesa no Brasil, Mercado japonês de trabalho, Dualismo no Mercado Japoneês. 


\begin{abstract}
KOJIMA, Lina. Repeated Migration between Brazil and Japan. 2009. $134 \mathrm{f}$. Dissertation (Mester) - Faculdade de Filosofia, Letras e Ciências Humanas, Universidade de São Paulo, São Paulo, 2009.

This dissertation's idea originated from the previous research about dekasegi phenomenon and Shuttle Migration, which title was "The Shuttle Migration of Brazilian Workers in Japan”. Since Brazilian workers' emigration to Japan, a so-called dekasegi phenomenon started, over 20 years have passed. And, this phenomenon has showed various changes. One of them is appearance of Shuttle Migration called Repeated Migration in this dissertation. The term refers to "the migrated people who goes and comes back between residential locations in different countries, often repeating this movement. Many of Brazilian workers in Japan try to return to Brazil, but frequently they can't readapt and go away again. In this dissertation, we'll try to understand causes of this repeated movement through the historical and structural contexts of both countries.
\end{abstract}

Keywords: Repeated Migration, Decasegi, Japanese Imigration in Brazil, Japanese labor market, dualism in Japanese Market. 


\section{ÍNDICE DE TABELAS E GRÁFICOS}

$\begin{array}{ll}\text { Gráfico 01: Ato coletivo } & 15\end{array}$

Gráfico 02: Ato individual $\quad 15$

Gráfico 03: EUA “integração piramidal”

Grágico 04: JAPÃO “semi-integração piramidal”

Tabela 01: A relação das circunstâncias japonesa, brasileira e a corrente migratória existente entre os dois países $\quad 15-16$

Tabela 02: A entrada de Imigrantes Japoneses no Brasil 67-69

Tabela 03: Número de imigrantes do pós-guerra, segundo sua categoria $74-75$

Tabela 04: População Brasileira no Japão 87 


\section{SUMÁRIO}

CAPÍTULO 1 - INTRODUÇÃO 09

$\begin{array}{ll}\text { 1.1 Introdução } & 09\end{array}$

1.2 Histórico da Imigração $\quad 09$

$\begin{array}{ll}\text { 1.3 Estrutura do Trabalho } & 11\end{array}$

CAPÍTULO 2 - HISTÓRIA DO BRASIL 18

2.1 Fase anterior à imigração japonesa no Brasil 18

2.1.1 Papel do café na economia brasileira 19

$\begin{array}{ll}\text { 2.1.2 Industrialização } & 21\end{array}$

2.2 Problema de dívidas externas $\quad \mathrm{xx}$

CAPÍTULO 3 - HISTÓRIA DO JAPÃO 27

3.1 Mudança econômica e social de 1868 até $1945 \quad 27$

3.1.1 Restauração Meiji 28

3.1.2 Emigração para a região asiática 35

3.2 Rápida recuperação econômica no período pós-guerra 36

3.2.1 Recuperação e o ressurgimento econômico do Japão 36

3.3 "Economia de Bolha" e a escassez de mão de obra 41 
3.4.1 Dualismo entre empresas japonesas 48

3.4.2 Sistema produtivo japonês: Toyotismo 53

CAPÍTULO 4 - IMIGRAÇÃO JAPONESA NO BRASIL 59

4.1 Origem e histórico da imigração japonesa no Brasil 59

4.1.1. Imigração japonesa nos países variados $\quad 59$

4.1.2. Imigração japonesa no países variados 63

4.1.3. Mudança da imigração japonesa no Brasil 69

4.2 Migração japonesa pós-guerra e sua cessação 72

CAPÍTULO 5 - FENÔMENO DECASSÉGUI 76

5.1 Revisão histórica da migração - Definição do fenômeno decasségui

5.1.1 Revisão histórica da migração - origem do movimento decasségui

5.2 Mudança do fenômeno decasségui $\quad 82$

5.2.1 Mudança do mercado de trabalho no Japão 87

5.2.2 Dualismo e função de empreiteira 91

5.3 Fenômeno do Invisible Residents $\quad 94$

5.3.1 Sistema trabalhista que transcende as fronteiras 97

CAPÍTULO 6 - MIGRAÇÃO REPETITIVA E PESQUISA DE CAMPO 
6.1 Migração Repetitiva 101

6.1.1 Definição da Migração Repetitiva 101

6.1.2 Migração Repetitiva no caso do decasségui 105

$\begin{array}{ll}\text { 6.2 Relato da pesquisa de campo } & 106\end{array}$

6.3 Considearções finais 117 


\section{CAPÍTULO 1 - INTRODUÇÃO}

\section{INTRODUÇÃO}

Iyotani (2000) empregou o termo Shuttle Migration referindo-se a "pessoas migrantes que vão e retornam entre locais de residência, no caso, situados em países diversos, repetindo muitas vezes esse "vai e volta". Enorme foi o interesse por esse fenômeno de Shuttle Migration, tanto que procuramos realizar um relatório a seu respeito, no caso, entre o Brasil e o Japão, com base na pesquisa bibliográfica.

Porém, ao longo da pesquisa realizada, através desse relatório, constatou-se que ainda não foi encontrado um trabalho atinente e convincente tratando sobre as causas desse movimento migratório, principalmente em relação ao lado brasileiro. Obviamente, a bibliografia desenvolvida no Japão tem se dedicado aos assuntos inerentes àquele país, mas há necessidade de se conhecer também circunstâncias do lado brasileiro, para melhor entender os fenômenos decasségui e Shuttle Migration. Assim, a ideia de desenvolver esta dissertação nasceu desta pesquisa realizada, intitulada $O$ Shuttle Migration dos brasileiros residentes no Japão, para a obtenção do grau de bacharel em Ciências Políticas em 2002, no Japão, sobre os fenômenos decasségui e o chamado Shuttle Migration e, posteriormente, para o aprofundamento do assunto no grau de mestrado. Neste trabalho pretende-se continuar tratando do mesmo tema Shuttle Migration, doravante chamado "Migração Repetitiva", o termo mais genérico, mais fácil de entender, que ainda não foi totalmente esclarecido pelas pesquisas existentes, procurando fatores causais não apenas do Japão, mas também do Brasil.

\subsection{Histórico da imigração}


A comemoração do Centenário da Imigração Japonesa no Brasil, no ano de 2008, agitou, sobremaneira, a comunidade nipo-brasileira japonesa no Brasil, como também os japoneses da Terra do Sol Nascente.

A imigração japonesa para o Brasil, iniciada em 1908, trouxe 781 pessoas denominadas isseis ( $1^{\mathrm{a}}$ geração). Ano a ano eles foram se multiplicando, até o ano de 1941, quando houve interrupção da corrente imigratória por causa da Segunda Guerra Mundial. Esta corrente somente retomou em 1953, e perdurou até 1973.

Hoje, após esses 100 anos, ao número de isseis ( $1^{\text {a }}$ geração) ainda sobreviventes, acrescentaram-se os nisseis ( $2^{\mathrm{a}}$ geração), sanseis ( $3^{\mathrm{a}}$ geração), yonseis ( $4^{\mathrm{a}}$ geração) e assim por diante inclusive os mestiços que, num total, perfazem cerca de 1.500 .000 habitantes.

No decorrer desses 100 anos, muitos aspectos econômicos, sociais e políticos, tanto do Brasil como do Japão, fizeram alterar a perspectiva do modo de vida dos japoneses de ambos os países. No Japão, após a Segunda Guerra Mundial, o povo, arrasado pela derrota, passava dificuldades de toda sorte. No Brasil, o sonho dos isseis de regressarem ao seu país natal, após acúmulo de certo capital, foi por água abaixo em razão dessa situação pós-guerra, e, assim, a maioria desses isseis resolveu permanecer definitivamente no Brasil. Renovando seus objetivos de vida, muitas famílias migraram para as cidades, a fim de proporcionar melhor escolaridade aos filhos, pois visavam, agora, realmente enraizar-se no Brasil, aspirando um nível de vida melhor, tanto econômico como culturalmente, para seus descendentes. Lutando arduamente com esses propósitos, no decorrer dos anos muitas famílias tiveram seus descendentes ocupando lugar de destaque em várias áreas da sociedade brasileira, desde agricultor, empresário, profissionais liberais, educadores, magistrados, e os cargos políticos, como vereadores, deputados, secretários de Estado, e até de Ministros. Esta luta veio sendo 
travada até meados da década de 1980, quando uma série de problemas econômicos, sociais e políticos ocasionaram desemprego em massa e hiperinflação, tornando cada vez mais difícil a sobrevivência, sobretudo das classes média baixa e baixa dos brasileiros.

Nessa época, o Japão estava passando pela falta de mão de obra não qualificada, e foi o momento exato e oportuno para os nikkei, que estavam em dificuldade, buscarem os trabalhos oferecidos pelo Japão, sobretudo aos imigrantes isseis ainda sobreviventes nos diversos países para onde haviam emigrado. Aí se inicia, desta vez, a corrente emigratória, denominada movimento decasségui, do Brasil para o Japão, em busca de um trabalho mais bem remunerado, em comparação com o Brasil, e, consequentemente, de melhores condições de vida. O movimento decasségui tem mostrado diversos aspectos em relação às características de emigrantes, de objetivos de ida e do modo de vida dessas pessoas no Japão. No decorrer deste movimento, enquanto uma parte desses trabalhadores permaneceu no Japão, a outra, após um certo tempo de permanência naquele país, acumulou recursos e retornou ao Brasil, a fim de atingir seus objetivos, traçados antes da partida. Contudo, apesar do empenho, em razão de uma série de dificuldades, muitos destes acabam fracassando e partindo novamente para o Japão, a fim de tentar novamente a obtenção de recursos. Nesse processo de deslocamento repetitivo, os imigrantes acabam não conseguindo se fixar nem no Japão, nem no Brasil. Este é o fenômeno chamado "Migração Repetitiva”, que será mais bem explicado a seguir.

\subsection{Estrutura do trabalho}

A ideia inicial deste trabalho foi pesquisar esse movimento repetitivo, mais especificamente dos trabalhadores brasileiros que, nos últimos anos, repetem as idas e voltas entre o Brasil e o Japão. Este movimento, chamado de Migração Repetitiva, é definido como 
um deslocamento por aqueles (brasileiros) que foram para o Japão como decasséguis, com o objetivo de trabalhar e de obter recursos financeiros, mas, após a tentativa de regresso e reinserção no Brasil, por algum motivo tiveram de retornar ao Japão. Porém, pelas dificuldades para a realização da pesquisa de campo, nesta dissertação serão focados mais os contextos histórico-estruturais dos dois países, que servem como pano de fundo desse movimento contínuo. Através da revisão bibliográfica, serão apresentados os fatos históricos que influenciaram no surgimento da corrente migratória entre o Brasil e o Japão, dando ênfase aos mercados de trabalho.

Para este trabalho, pressupõem-se duas ideias básicas: a primeira, de que os movimentos migratórios entre o Brasil e o Japão são uma corrente contínua das pessoas. A segunda, de que essa corrente migratória é influenciada pelas circunstâncias dos dois países.

Esse movimento migratório recebeu denominações peculiares em diferentes momentos: desde o Kasato-Maru até os meados de 1980, a corrente migratória que se direcionou para o Brasil recebeu a denominação "imigração japonesa". Porém, após meados da década de 1980, quando imigrantes japoneses iniciaram o caminho inverso, isto é, do Brasil para o Japão, foram denominados "decasséguis". Agora, como referido acima, entre os trabalhadores decasségui, aqueles que repetem as idas e voltas entre Brasil e Japão serão chamados de migrantes repetitivos. Assim como cada indivíduo migrante possui sua experiência particular, cada fenômeno migratório traça suas características peculiares, sendo influenciado pelo contexto histórico, também peculiar. Sasaki (1999) comenta:

O processo migratório, assim como a identidade cultural, "não é jamais uma essência fixa que se mantenha imutável, fora da história e da cultura" (HALL, 1996:70). Em um movimento migratório, não existe uma única experiência, homogênea, vivenciada e contemplada da mesma maneira pelos migrantes/atores sociais. (SASAKI, 1999, p. 257) 
A imigração japonesa para o exterior não se iniciou apenas na era Meiji. ${ }^{1}$ No final do século XVI já havia a presença dos emigrantes japoneses na região do sudeste asiático, principalmente na atual Tailândia, assimilados no decorrer do tempo pela população local. A imigração japonesa para o Brasil, no início do século $\mathrm{XX}$, poderia ter sido um movimento populacional, "convencional”, como referido por Duany (2002, p. 359), constituída das formas lineares e irrevogáveis, segundo a qual os imigrantes se desligam permanentemente do seu país de origem e se predispõem à inevitável assimilação pela sociedade do país receptor. De fato, houve uma ampla assimilação pela sociedade brasileira dos nikkei. ${ }^{2}$ Porém, no atual mundo globalizado, os movimentos migratórios não mostram mais as características da migração convencional como acima referidas. A migração não é mais um ato definitivo e irrevogável.

Como um exemplo, Duany cita o caso de circular migration, ${ }^{3}$ dos porto-riquenhos entre os EUA e o Porto Rico. Segundo Duany (2002), entre a ilha de Porto Rico e o continente existe uma corrente bilateral das pessoas, chamada de circular migration. Esse fenômeno “desafia a ideia convencional do movimento populacional (...) contém a definição da identidade cultural no sentido lato (...), corroe a definição convencional de cidadania e de nacionalidades". (DUANY, 2002, p. 356-360)

Duany escreve também:

os outros pesquisadores abordam a circulação como uma estratégia flexível para a sobrevivência (...), a migração circular constitui a prática de vida espacialmente estendida. Portanto, o movimento frequente pode ser interpretado como um efeito, em vez da causa, da pobreza persistente, da baixa qualidade de vida e das reduzidas oportunidades para o progresso na

\footnotetext{
1 Meiji: O nome do reinado e do imperador da época. A era Meiji durou de 1868 a 1912.

2 Segundo os dois recenseamentos sobre a população de imigrantes e de descendentes de japoneses residentes no Brasil (1958 e 1988), as porcentagens de casamentos interétnicos são as seguintes: em 1958, o casamento de um nikkei com uma ocidental era de $3,80 \%$, enquanto uma nikkei com um brasileiro era de $0,87 \%$ (Comissão de recenseamento da colônia japonesa, 1964, p. 533). E, em 1988, a porcentagem total foi de 45,9\% (Centro de Estudos Nipo-Brasileiros, 1990, p. 86).

3 Circular migration: a corrente bilateral das pessoas entre o Porto Rico e os Estados Unidos (DUANY, 2002, p. $355)$.
} 
ilha [de Porto Rico] ${ }^{4}$ e no continente. (DUANY, 2002, p. 361)

Ou seja, esse movimento circular entre os EUA e Porto Rico, em que "as pessoas vêm e vão conforme as circunstâncias mudam aqui e lá” (DUANY, 2002, p. 363), é considerado, por certos pesquisadores, como uma "estratégia flexível para a sobrevivência".

No caso da circular migration acima referido, tratando-se de uma vida individual, considera-se que uma pessoa, no decorrer de sua vida, repete as idas e voltas conforme as mudanças de circunstâncias. A argumentação do presente trabalho é de que essa busca de estratégia flexível para a sobrevivência acontece não apenas na vida individual de um imigrante, mas também numa corrente migratória, através de gerações. Destarte, a imigração japonesa no Brasil e o movimento decasségui são partes de uma corrente contínua de pessoas que buscam sua estratégia de sobrevivência conforme as mudanças de circunstâncias dos dois países. Os gráficos 1 e 2, abaixo, indicam, respectivamente, a corrente migratória entre o Japão e o Brasil (ato coletivo) e circular migration (ato individual) entre os Estados Unidos e Porto Rico. As setas indicam o sentido do fluxo humano. Nota-se que enquanto a circular migration entre os EUA e Porto Rico é um ato individual, a corrente migratória existente entre o Brasil e o Japão ocorre como um ato coletivo.

\section{Corrente migratória}

\footnotetext{
${ }^{4}$ Interferência da autora.
}

Circular migration 
B

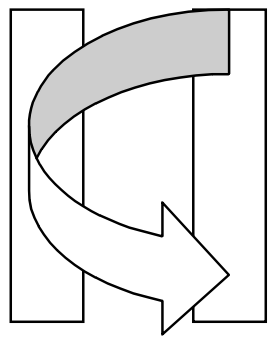

Gráfico 1 - Ato coletivo
EUA PR

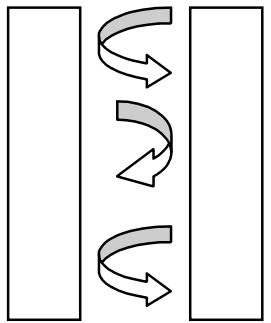

Gráfico 2 - Ato individual

Desde a chegada da primeira imigração japonesa ao Brasil em 1908, indubitavelmente as condições sociais, econômicas e políticas dos dois países mudaram drasticamente. Pode-se dizer que, de um lado, os imigrantes japoneses vieram ao Brasil atendendo a um chamamento de fazendeiros cafeeiros e impulsionados pelas condições precárias de vida japonesa antes e logo depois da Segunda Guerra Mundial; por outro lado, nas gerações posteriores, os nikkei foram buscar uma nova forma de sobrevivência, influenciados pelas circunstâncias peculiares japonesas e brasileiras, dos anos 1980 para 1990. No presente trabalho, procura-se esclarecer esta relação através da apresentação dos fatos históricos dos dois países.

A tabela abaixo indica esta relação da imigração japonesa no Brasil e do movimento decasségui.

\begin{tabular}{|l|l|l|l|}
\hline Ocorrências & Circunstâncias do & Corrente & \multicolumn{1}{|c|}{ Circunstân } \\
& Japão & migratória & demanda \\
Guerra Mundial & mão de obra & japonesa no Brasil & de mão de obra na \\
\hline antes da $2^{\mathrm{a}}$ & & área rural \\
\hline após a $2^{\mathrm{a}}$ & devastação & decisão de & \\
\hline
\end{tabular}




\begin{tabular}{|c|c|c|c|}
\hline Guerra Mundial & econômica & $\begin{array}{l}\text { permanecer no Brasil } \\
\text { e a migração para as } \\
\text { cidades }\end{array}$ & urbanização \\
\hline $\begin{array}{r}\text { dos anos } \\
1950 \text { para os anos } \\
1970\end{array}$ & $\begin{array}{l}\text { da } \\
\text { recuperação } \\
\text { pós-guerra para o } \\
\text { rápido crescimento }\end{array}$ & $\begin{array}{l}\text { a gradual } \\
\text { ascensão social }\end{array}$ & $\begin{array}{l}\text { da } \\
\text { industrialização para a } \\
\text { grave crise econômica }\end{array}$ \\
\hline $\begin{array}{l}\text { dos anos } \\
1980 \text { para os anos } \\
1990\end{array}$ & $\begin{array}{l}\text { escassez de } \\
\text { trabalho }\end{array}$ & $\begin{array}{l}\text { crise } \\
\text { econômica brasileira } \\
\text { afeta os nikkei } \\
\text { fenômeno } \\
\text { decasségui }\end{array}$ & $\begin{array}{l}\text { consequência da crise } \\
\text { econômica gera } \\
\text { insegurança social }\end{array}$ \\
\hline
\end{tabular}

Tabela 1 - A relação das circunstâncias japonesa e brasileira, e a corrente migratória existente entre os dois países.

As segunda e quarta colunas indicam, respectivamente, os fluxos das histórias brasileira e japonesa. Para resumir, de um lado, no Japão, após a Restauração Meiji em 1868, o país passou por um duro e longo processo de modernização, com abundância de mão de obra, incentivando a emigração do seu povo. Passando pela derrota da Segunda Guerra Mundial, a situação continuou até nos anos 1960. Depois disso, o país começou a erguer-se como uma grande potência econômica. A partir dos anos 1980, por vários motivos (diminuição da população, baixa natalidade, envelhecimento da população, elevada escolaridade dos jovens e, consequentemente, sua fuga dos trabalhos monofuncionais, etc.), o Japão começou a sentir falta de mão de obra, o que incentivou o aparecimento do movimento decasségui.

Por outro, no Brasil, com a abolição da mão de obra escrava, a área da agricultura, 
principalmente para a plantação de café, passou a necessitar de mão de obra imigrante. Foi assim que o processo da imigração japonesa no Brasil iniciou-se em 1908. No decorrer do século XX, paralelamente ao processo da urbanização brasileira, os imigrantes japoneses ascenderam socialmente e estabeleceram seu status de model minority. ${ }^{5}$ Porém, sofreram as consequências da crise brasileira nos anos 1980 e, assim, iniciaram o processo emigratório no sentido inverso.

O presente trabalho divide-se em seis capítulos. Neste, foi apresentado um resumo dos fatos relacionados à corrente migratória entre o Brasil e o Japão; nos capítulos 2 e 3 serão abordados os contextos históricos brasileiro e japonês, enfatizando seu aspecto econômico; nos 4 e 5 serão apresentadas as características gerais da imigração japonesa no Brasil e do movimento decasségui, inclusive em termos de números, esclarecendo as causas desses movimentos migratórios a partir dos contextos históricos anteriormente abordados nos capítulos 2 e 3; e, por fim, no capítulo 6 será tratada a Migração Repetitiva (circular migration), etc.

\footnotetext{
${ }^{5}$ Model minority refere-se, étnica, racial ou religiosamente, à minoria cujos membros atingem um grau de sucesso maior que a população geral.
} 


\section{CAPÍTULO 2 - HISTÓRIA DO BRASIL}

\subsection{Fase anterior à imigração japonesa no Brasil}

A primeira leva de imigrantes japoneses chegou ao Brasil no dia 18 de junho de 1908, exatamente cem anos atrás. Porém, para entender a origem dessa imigração, precisamos conhecer uma fase anterior à sua chegada.

As circunstâncias nacionais e internacionais, na segunda metade do século XIX, levaram o Brasil à abolição da escravatura em 1888. Este fato, junto com a expansão da cafeicultura, resultou numa crise de falta de mão de obra, que foi a principal causa da introdução da imigração europeia em grande massa. Porém, no decorrer do tempo, esses imigrantes europeus não se apresentavam aptos às exigências dos fazendeiros, principalmente pela sua alta mobilidade. Os imigrantes que trataram de sair das atividades agrícolas afluíram às cidades. À época, São Paulo mostrou o mais alto índice de urbanização, registrando aumento de $268 \%$ da população entre 1890 e 1900 (FAUSTO, 2007, p. 286).

A demanda por imigração oriental surgiu neste contexto. Arlinda Rocha Nogueira (1984) apresenta como foi o processo de argumentação sobre a introdução da imigração oriental, no Brasil, esclarecendo as circunstâncias históricas da época, principalmente do Estado de São Paulo.

Na época, no Brasil, o fator café era imprescindível. Desde meados do século XIX até início do século XX, o negócio do café era a mais importante fonte de receitas. A importância do café nesse período foi tanta, que o sucesso da lavoura do café em São Paulo, durante as três primeiras décadas do século XX, levou o Estado a se tornar um dos mais ricos do país, fazendo com que vários fazendeiros indicassem ou se tornassem eles próprios presidentes da República 
(a política conhecida como "café com leite", por se alternarem na presidência paulistas e mineiros). Nessas circunstâncias, a introdução da imigração oriental (cujo corpo principal era formado por chineses e japoneses) provocou muita argumentação contrária, porém, diante da escassez de mão de obra nas fazendas de café e das exigências dos fazendeiros, os governos brasileiro e estadual paulista viram-se obrigados a aceitar quaisquer trabalhadores, independente da sua origem. Foi assim que começou a imigração japonesa no Brasil, no início subvencionada pelo governo estadual paulista.

\subsubsection{O papel do café na economia brasileira}

Durante o período da República Velha (1889-1930), no qual a introdução da imigração japonesa iniciou-se, a economia brasileira foi caracterizada pelo bom desempenho das agroexportações, principalmente de café. Esta modalidade da economia foi chamada de "modelo de desenvolvimento voltado para fora", que continha o risco de elevada vulnerabilidade (HADDOCK LOBO, 1949, p. 230). Os produtos exportados à época eram café, açúcar, ouro, algodão, borracha, etc. Mas, o café era o eixo da economia brasileira. $\mathrm{Na}$ pauta das exportações, ele ocupou uma média em torno de $60 \%$ do valor total e, no fim do período, representava em média 72,5\% das exportações (FAUSTO, 2005, p. 273).

Nunca é demais ressaltar a importância do café nesta época. A introdução do produto, no Brasil, deve-se ao português Francisco de Melo Palheta em 1723 (HADDOCK LOBO, 1949, p. 128). O café chegou na década de 1770 ao Rio de Janeiro e, mais tarde, estendeu-se para a região do Vale do Paraíba, para o Oeste paulista e para o Norte do Paraná (NOGUEIRA, 1984, p. 53).

No Vale do Paraíba, a cafeicultura, que floreou principalmente nos meados do século 
XIX, já no final deste século encontrava-se em decadência. Ali, a cafeicultura causava erosão do terreno, e a ausência absoluta de adubo piorava a situação, resultando em empobrecimento ou "gasto" mais ou menos rápido do solo onde se cultivava o café. Assim, os cafeicultores se deslocavam, à procura de terras virgens, para o oeste da capital paulista e, mais tarde, para a região Norte do Paraná, num deslocamento chamado de "onda verde" (HADDOCK LOBO, 1949, p. 132-133).

Entre 1890 e 1900, segundo Paulo Pestana, “plantar café em São Paulo se tornava verdadeira especulação inicitada pelos altos preços" (NOGUEIRA, 1984, p. 60). O desenvolvimento da lavoura só foi possível através da "participação da finança internacional, que, após a República, passou a ocupar um certo espaço na economia brasileira, e do imigrante (...) que veio em socorro dos fazendeiros" (NOGUEIRA, 1984, p. 60). Porém, a economia, que girava em torno praticamente de um só produto, fatalmente ficava nas mãos do mercado internacional, sofrendo as consequências das oscilações deste mercado, frágil e vulnerável. A partir de 1897, houve um grande desequilíbrio entre a produção e o consumo, mostrando umo primeiro sinal da crise de superprodução. No início do século XX, o café brasileiro passou a sofrer desvalorização. Apesar das tentativas de intervenção por parte do governo, no sentido de segurar os preços, como o Convênio de Taubaté, em 1906, o produto continuava a decair.

“A exportação de café dependia das oscilações no crescimento mundial, aumentando em momentos de prosperidade econômica e retraindo-se quando os países ocidentais (especialmente EUA e Inglaterra) entravam em crise ou em guerra" (VASCONCELLOS et al., 1999, p. 229). Assim, as crises internacionais resultavam nos problemas de exportação de café que, praticamente, afetariam todas as outras atividades dentro do país, porque estas dependiam direta ou indiretamente de desempenho do setor exportador cafeeiro.

Durante o período agroexportador, os outros setores econômicos possuíam um baixo 
nível de produtividade e eram incapazes de conferir dinamismo à economia brasileira, dadas as elevadas condições de rentabilidade da economia cafeeira, especialmente em épocas de ausência de crise internacional. Assim, os recursos existentes no país acabaram convergindo para esta atividade. Esta convergência de recursos em função da rentabilidade do setor é a base para a chamada superprodução, que se configurou como uma tendência da economia cafeeira nos últimos anos da República Velha.

As condições no mercado internacional de café tendiam a tornar-se mais problemáticas à medida que as plantações do produto no Brasil se expandiam. Nas primeiras décadas do século XX, a produção brasileira cresceu desmensuradamente. O Brasil chegou a produzir, sozinho, mais café do que todo o consumo mundial, obrigando o governo a intervir no mercado, estocando e queimando café. Essas intervenções protetoras à economia cafeeira acabaram por reforçar a tendência de superprodução do café. Neste período, as crises ocorreram em função tanto de oscilações na demanda (crises internacionais), como em decorrência da própria superprodução brasileira.

Em 1930, estes dois elementos conjugaram-se, a produção nacional era enorme e a economia mundial entrou numa das maiores crises da sua história (VASCONCELLOS et al., 1999, p. 230).

Com a "quebra" da Bolsa de Valores americana em 1929, o Brasil passou por uma grande crise de superprodução do café, obrigando o o governo a promover a queima de estoques para tentar segurar os preços. Após esse ano, o café perdeu definitivamente a importância que mantinha na economia brasileira.

\subsubsection{Industrialização}


A primeira tentativa de industrialização, no início da era republicana, não produziu um resultado desejado, pois era-nos impossível fabricar as máquinas e utensílios, tendo que depender das importações (VASCONCELLOS et al., 1999, p. 151). Em diversos casos, quando possuíamos a matéria-prima principal, como acontecia com a borracha, faltavam-nos outras substâncias necessárias ao seu aproveitamento (VASCONCELLOS et al., 1999, p. 153).

As indústrias brasileiras iniciaram seu desenvolvimento apenas no século XX. A partir do primeiro decênio deste século, êxitos notáveis foram alcançados, principalmente das pessoas de origem imigratória recente, sobretudo dos imigrantes europeus no final do século XIX e no início do século XX (VASCONCELLOS et al., 1999, p. 154). Isto graças à tradição técnica ou comercial que esses imigrantes haviam trazido dos seus países de origem (VASCONCELLOS et al., 1999, p. 154). Nas empresas manufatureiras da capital de São Paulo, em 1893, 70\% de seus integrantes eram estrangeiros (FAUSTO, 2007, p. 288).

Limitando-se ao contexto do Estado de São Paulo, as origens do crescimento industrial, na época, foram as duas fontes inter-relacionadas: o setor cafeeiro e os imigrantes (FAUSTO, 2007, p. 286-289). Os negócios cafeeiros formaram as bases para o primeiro surto da indústria paulista. A contribuição do café na industrialização foi: a) promover a imigração e os empregos urbanos vinculados ao complexo cafeeiro, criando um mercado para produtos manufaturados; b) promover o investimento em estradas de ferro, ampliando e integrando esse mercado; c) desenvolver o comércio de exportação e importação, contribuindo para a criação de um sistema de distribuição de produtos manufaturados; d) oferecer moeda estrangeira obtida através da exportação do café para importação de máquinas industriais (FAUSTO, 2007, p. 287). A exportação de café trouxe os capitais estrangeiros para o país, que incentivariam o surgimento de bancos, comércios e indústrias, e promoveriam a importação de máquinas industriais. Além disso, os imigrantes trazidos por causa desse produto acabaram 
colaborando não só para a produção do café, mas também para a diversificação agrícola e para a formação do mercado interno. Quanto à diversificação agrícola, estimulada pela demanda das cidades em crescimento, a produção de arroz, feijão e milho expandiu-se (FAUSTO, 2007, p. 284). A respeito da formação do mercado interno, os imigrantes, aspirando à ascensão social, procuraram seu caminho nas incipientes atividades comerciais e industriais, como donos de empresas, operários e também como técnicos especializados (FAUSTO, 2007, p. 287). Assim, tornaram-se os fabricantes e consumidores ao mesmo tempo, formando um mercado interno. A estrada de ferro, também construída para transporte de café, ampliou e integrou este mercado.

Os principais ramos industriais que surgiram na época foram: têxtil, que se desdobrou na confecção de vestuário, de produtos de uso do cotidiano; produtos alimentícios; bebidas variadas; etc. Apesar desse relativo avanço na produção industrial, havia profunda carência de uma indústria de base (cimento, ferro, aço, máquinas e equipamentos). Assim, grande parte do surto industrial dependia de importações. Além disso, nessa época, o governo brasileiro não dava importância para a indústria. Sua maior preocupação estava concentrada nos interesses agroexportadores. O Estado não adotou um comportamento anti-industrialista, porém, não chegou a incentivá-la (FAUSTO, 2007, p. 289).

Segundo Haddock Lobo (1949, p. 160), as influências da Primeira Guerra Mundial (1914-1918) no Brasil caracterizaram-se pela cessação de imigração e pelo surgimento de indústrias. As dificuldades de transporte marítimo e a diminuição de produtividade de usinas europeias permitiram às indústrias brasileiras um surto animador. A qualidade dos artigos manufaturados passou a melhorar e, entre as várias indústrias, a de algodão começou a progredir, pois existia a matéria-prima necessária. Quando a guerra terminou, a proteção alfandegária garantiu aos industriais a manutenção do terreno conquistado nos mercados 
internos (HADDOCK LOBO 1949, p. 160).

Contudo, o verdadeiro processo de industrialização iniciou-se a partir dos anos 1930. Como já referido, após a crise econômica de 1929 a exportação de café entrou em crise, o que causou uma consciência da necessidade de industrialização no país. O fim da República Velha, uma república descentralizada, também ajudou a definir a industrialização como uma meta prioritária. Essa fase inicial do processo de industrialização é chamada de PSI (processo de substituição da importação pela produção nacional), que incentivou o crescimento da produção de produtos nacionais capazes de substituir os importados. Como faltavam as divisas obtidas pela exportação, o processo dependia de investimento externo e, a partir dos anos 1930, esse processo perdurou por três décadas.

No início do governo getulista, a política industrialista ainda estava indefinida, porém, já na fase do Estado Novo (1937-1945) o governo mostrou maior decisão no implemento do PSI, com realizações econômicas voltadas gradativamente aos objetivos de promover a industrialização, principalmente para a formação das indústrias de base.

O processo de industrialização chegou ao seu auge nos anos 1950. Principalmente quando, no contexto do Plano de Metas do governo Juscelino Kubitschek (1956-1961), foram adotadas várias medidas para incentivar o desenvolvimento econômico, como transporte e energia. Nessa fase, destaca-se a instalação de indústrias automobilísticas na região do $\mathrm{ABC}$ paulista (Santo André, São Bernanrdo do Campo, e São Caetano do Sul).

Após um curto período de dificuldades no início dos anos 1960, o PSI continuou nas mãos do governo militar. A partir do final dos anos 1960 até o primeiro Choque do Petróleo, ${ }^{6}$

\footnotetext{
${ }^{6}$ Choque do Petróleo: As crises socioeconômicas causadas, em 1973, nos países desenvolvidos, em razão da cessação do abastecimento ou da elevação dos preços do petróleo pelas estratégias dos países produtores de petróleo (principalmente os do Oriente Médio). Em 1979, houve um segundo choque, influenciado pela Revolução do Irã.
} 
o Brasil passou por uma fase chamada de "milagre brasileiro", no qual se combinou "o extraordinário crescimento econômico com taxas relativamente baixas de inflação” (FAUSTO, 2007, p. 485). Nesse período, favorecido pela economia mundial, o PIB cresceu, na média anual, 11,2\%, tendo seu pico em 1973, com uma variação de 13\% (FAUSTO, 2007, p. 485). Porém, esse milagre dependia fortemente de dívidas externas e de investimentos de capitais estrangeiros. Além disso, necessitavam da importação de determinados produtos, como o petróleo. Após o primeiro Choque do Petróleo em 1973, o governo brasileiro foi obrigado a optar por um ajustamento em relação à atuação econômica mundial, ou um prosseguimento de crescimento econômico no país. Ressalta-se que o Brasil, nessa época, estava sendo governado pela forças armadas, que não pretendeu adotar uma orientação econômica recessiva. A opção do governo foi dar continuidade ao processo de desenvolvimento, com endividamento externo.

A dívida externa cresceu rapidamente, US\$15 bilhões entre 1974/1977, e mais US\$17 bilhões em 1978/1979 (VASCONCELLOS et al., 1999, p. 265). O Estado foi assumindo os juros baixos num sistema de taxas de juros flutuantes.

Quando as taxas de juros elevaram-se bruscamente pela reversão nas condições de financiamento internacional decorrente do segundo Choque do Petróleo (1979) e da alteração na política econômica norte-americana, "a situação de endividamento, que parecia estar sob controle, mostrou-se insustentável" (VASCONCELLOS et al., 1999, p. 269). As tentativas de resolver o problema da dívida externa, o chamado processo de ajustamento externo, causaram uma profunda recessão entre 1981/1983 e a hiperinflação por toda a década de 1980 . O governo brasileiro, que agora tornou-se um governo civil, adotou os variados modelos. Esses modelos não deram resultados, e eram cada vez mais questionados por grande parte da população, que tinha o desemprego como ameaça latente (VASCONCELLOS et al., 1999, p. 270-272). 
Os anos 1980 no Brasil ficaram conhecidos como a "década perdida". A despeito do processo de democratização na esfera política, na esfera econômica as condições de vida da população brasileira deterioraram-se. “Em 1985 (...) a economia brasileira mostrou uma taxa de desemprego sem precedentes (12.5\%), o nível de inflação na casa de três algarismos" (MORI, 2002, p. 239).

O ponto culminante de uma série de planos anti-inflacionários foi o Plano Collor, já em 1990, que consistia basicamente na retirada de moeda de circulação mediante um confisco dos numerários depositados em estabelecimentos bancários. Como Corrêa Costa diz, o Plano Collor foi o marco histórico do movimento decasségui, dando grande ímpeto ao fator de repulsão (CORRÊA COSTA, 2007, p. 42). 


\section{CAPÍTULO 3 - HISTÓRIA DO JAPÃO}

\subsection{Mudança econômica e social de 1868 até 1945}

Desde o início do século XVII até o meado do século XIX, o Japão encontrava-se na era Edo (1600-1867), cujo sistema feudalista era constituído pelo governo militar xogunato ${ }^{7}$ (Edo Bakufu) e pelos senhores que dominavam os agricultores nos feudos. O regime político da época era mantido com base na rígida divisão de classes e na política de isolamento do país. As classes foram divididas em quatro: militar (samurai), agricultor, artesão e comerciante, e, basicamente, era impossível a transferência de uma a outra. Durante quase todo esse período, o governo militar xogunato manteve o país isolado do resto do mundo, exceto por limitados contatos com a China, a Coreia e a Holanda. Os objetivos dessa estratégia foram: impedir a expansão do cristianismo, uma religião considerada nociva pela autoridade; restringir o comércio exterior; e manter uma estrutura social, política e econômica fechada. Dessa forma, o governo proibia a saída da sua população para o estrangeiro e, ao mesmo tempo, impedia a passagem de navios estrangeiros aquém do seu limite territorial. Contudo, desde meados do século XVIII, esse regime econômico fechado mostrou vários problemas, tais como: superpopulação, desemprego real e potencial, baixa produtividade agrícola e industrial (SBCJ, 1992, p. 28), e empobrecimento da classe de militar. No final da era Edo, a população japonesa somava cerca de 30 milhões, assim constituída: $84 \%$ da classe de agricultores, $7 \%$ de militares, e os restantes 9\% representavam as demais classes (SBCJ, 1992, p. 27).

Em 1853, a esquadra americana liderada pelo Comodoro Matthew C. Perry chegou ao

\footnotetext{
${ }^{7}$ Xogunato (shôgun): inicialmente, um posto no exército. O xogum, que era o enviado para debelar os bárbaros do leste, passou a designar o líder do governo militar, com poderes não raro superiores aos do imperador.
} 
Japão exigindo a abertura do país ao comércio exterior. Um ano depois, em 1854, o Tratado de Kanagawa foi assinado com os Estados Unidos, abrindo os portos japoneses de Shimoda e de Hakodate para esse comércio, garantindo a segurança dos marinheiros estadunidenses e estabelecendo ali um consulado permanente. Este tratado acabou definitivamente com a política de isolamento do Japão. Outros países, como Inglaterra, Rússia e Holanda, seguiram esse exemplo e firmaram semelhantes tratados (HITOMI et al., 1996, p. 166).

\subsubsection{Restauração Meiji}

Apesar das tentativas de abertura do país e de modernização, o governo militar xogunato não conseguiu conter a insatisfação da população. Os adversários mais ferozes eram os senhores dos feudos importantes, como Satsuma, Chôshû e Tosa, e, principalmente, os militares desses feudos, de patente mais baixa. De 1867 a 1868, eles exigiram ao xogunato a renúncia do poder político e, posteriormente, junto com os nobres da corte, restabeleceram o regime político imperial. Esse processo de reforma política, que derrotou o governo militar xogunato, chama-se Restauração Meiji.

Após a revolução, o novo governo Meiji, formado pelos militares de alguns determinados feudos e pelos nobres, promoveu várias políticas de modernização sob o mote “enriquecer o país e fortalecer as forças armadas”. Algumas das principais mudanças foram: abolição do sistema de classes e a consequente tentativa de nivelar as classes sociais; permissão de uso de sobrenome para os plebeus; possibilidade de casamento entre classes diferentes; livre escolha de profissão; liberdade de produção rural (sem restrição aos produtos a serem plantados na lavoura); e liberação de venda de terrenos rurais (HITOMI et al., 1996, p. 175-177). 
Para a modernização, o governo Meiji tomou a iniciativa de promover o desenvolvimento industrial e introduzir o capitalismo no país. Durante o período da era Edo, o comércio foi desenvolvido até certo ponto, e, ao mesmo tempo, o crescente número de trabalhadores rurais desocupados foram forçados a migrar para as cidades, ali trabalhando em diversas atividades industriais. Contudo, o Japão ainda estava na fase preliminar de desenvolvimento econômico, cuja indústria manufatureira encontrava-se em fase embrionária. Diferentemente do Japão, nos países ocidentais a Revolução Industrial já havia acontecido há décadas, e o capitalismo estava crescendo e entrando em sua fase de maturidade (NARIAI, 1999, p.7).

A diferença do desenvolvimento econômico entre o Japão e o Ocidente era tanta, e a pressão pela modernização tão forte para o Japão, que este país não podia simplesmente esperar que sua economia se desenvolvesse em seu ritmo normal. Assim, foi necessário que o governo japonês tomasse a iniciativa de acelerar seu crescimento econômico, importando tecnologias industriais avançadas e métodos de administração do exterior, implantando um ambiente de produção que tendia, cada vez mais, à modernização (NARIAI, 1999, p. 7).

Nessa época, a dependência do Estado em relação à introdução do capitalismo, como o caso do Japão, era uma prática comum entre os países subdesenvolvidos. Os esforços feitos pelo governo japonês para desenvolver a indústria eram, em primeiro lugar, direcionados para melhorar a infraestrutura física e institucional em áreas como: transporte, comunicação, finanças e sistema monetário (NARIAI, 1999, p. 7).

O governo administrava diretamente as indústrias mais importantes, para que pudessem importar e implantar as tecnologias e os métodos de administração dos países industriais, objetivando, consequentemente, atingir a meta de aumentar a riqueza nacional. Essas empresas estatais foram equipadas com as facilidades importadas pelo governo e 
operadas pelos engenheiros estrangeiros (NARIAI, 1999, p. 7).

Uma dessas áreas estrategicamente utilizadas pelo governo, a fim de atingir seus objetivos, ou seja, de "enriquecer o país e fortalecer as forças armadas", foi a da indústria têxtil. Nessa tarefa de exportação e importação, o governo exportava seda crua ${ }^{8}$ e linhas de algodão, a fim de obter, através de divisas levantadas com o pagamento, não só equipamentos modernos para suas indústrias, como também armamentos para equipar as forças armadas. Assim, o governo tentava duplamente satisfazer o que era, naquele momento, de extrema importância: desenvolver a indústria e armar-se militarmente. Durante toda a era Meiji, as sedas cruas mantinham o primeiro lugar dos itens exportados, e o segundo era ocupado pelo algodão, superando o chá, antes nesta colocação (NARIAI, 1999, p. 7).

Para promover o desenvolvimento industrial e reforçar os poderes militares, assim como para encontrar renda necessária para liquidar, paulatinamente, as antigas classes dominantes do regime feudal (os samurais) de maneira razoável, o governo dependia ainda da arrecadação de impostos em geral (arroz, chá, tabaco, seda, etc.).

Após seu poder político tornar-se razoavelmente estável, em 1875, o governo Meiji lançou o plano da reforma do imposto fundiário, que foi completado em 1881, que compreendia sua modernização e a implantação de uma alíquota uniforme nacional, e o pagamento em dinheiro, cujo impacto foi maior na área da agricultura (NARIAI, 1999, p. 8).

Outro impacto significativo deu-se com a intensificação do êxodo rural. Em primeiro lugar, os novos impostos eram cobrados dos donos do terreno, e não de seus usuários, como era comum no antigo sistema feudal, o que resultava na determinação da posse de terreno e na promoção do êxodo rural. Os agricultores, que não queriam pagar os impostos, desistiram de suas posses do terreno comum, que costumava ser aberto ao uso público. Esses terrenos

\footnotetext{
${ }^{8}$ Seda crua: seda em rama, ou seda apenas fiada ou torcida, em fase de preparação para tecer; seda bruta.
} 
tornaram-se propriedade do governo, e os agricultores perderam o direito de obter o adubo, alimentos e lenhas produzidos nesses terrenos (NARIAI, 1999, p. 9).

Em segundo lugar, os novos impostos fundiários eram pagos em dinheiro. Com isso, os agricultores eram obrigados a vender seus produtos, e os agricultores pobres passaram a depender cada vez mais dos mais prósperos, além do fato de comerciantes e usurários passarem a invadir cada vez mais a agricultura. Os pobres agricultores, que não conseguiam controlar a venda dos seus produtos, foram obrigados a aceitar preços desvantajosos e ficar sob o controle desses comerciantes e usurários. Assim, a reforma do imposto fundiário resultou no êxodo rural e na expansão do mercado doméstico (NARIAI, 1999, p. 9).

Além da renda obtida através do imposto, o governo dependia também de títulos do Tesouro e de emissão de notas. Após a Revolta de Satsuma, em 1877, a excessiva emissão de títulos e de notas causou a inflação. Na década seguinte, o Ministro da Fazenda, Masayoshi Matsukata, tomou radicais medidas deflacionárias, aumentando receitas através da criação de novos impostos, reduzindo custos através do corte de despesas, da transferência de departamentos, do governo central para o local, e da privatização de empresas estatais ineficientes. Nesse processo, a base do capitalismo foi constituída com grande sacrifício. Os agricultores empobreciam, as pequenas empresas foram à falência e as famílias de antigos militares caíram em desgraça, causando um descontentamento social (NARIAI, 1999, p. 9-10). A industrialização japonesa se iniciou com a indústria leve, ${ }^{9}$ inclusive a indústria têxtil, que mostrou o mais notável desenvolvimento. As empresas privadas, no momento da inauguração com pouco capital, tinham dificuldades para implantação de indústria pesada. ${ }^{10}$ Além disso, havia as demandas nacionais e internacionais dos produtos da indústria leve, e o

\footnotetext{
${ }^{9}$ Indústria leve: denominação genérica das indústrias de bens de consumo.

${ }^{10}$ Indústria pesada: a que fabrica material de infraestrutura e máquinas e ferramentas pesadas.
} 
custo de mão de obra japonesa, na época, era baixo. Assim, a indústria leve combinava bem com a circunstância reinante então. $\mathrm{O}$ desenvolvimento da indústria pesada só se deu após a Primeira Guerra Sino-japonesa, de 1894 a 1895 (NARIAI, 1999, p. 12-13).

O governo Meiji, desde logo após a revolução, interessou-se pelo controle da Coreia que, na época, estava sob o domínio da China. Em 1894, Japão e China entraram na Primeira Guerra Sino-japonesa, da qual o Japão saiu vitorioso. Nessa vitória, além da posse de diversas regiões da China, o Japão conseguiu indenização de aproximadamente 3.1 milhões de ienes (na época), com a qual cobriu as despesas militares (HITOMI et al., 1996, p.195).

Após essa guerra, a economia japonesa encontrava-se em estagnação, porém, a indústria pesada cresceu em níveis excepcionais (NARIAI, 1999, p. 14). O governo, preocupado com o atraso do desenvolvimento da indústria pesada, como de ferro, de aço e de construção naval, tomou iniciativas para sua promoção. Os estaleiros e as usinas siderúrgicas foram construídos nessa época (NARIAI, 1999, p.14).

Em 1904, o Japão entrou em guerra com a Rússia, disputando o domínio da região nordeste chinesa. Na esfera econômica, sua maior preocupação era como arcar com as excessivas despesas dessa guerra. Além do aumento de impostos e de emissão de títulos nacionais, o governo precisou depender da dívida externa, e terminou por sofrer com a alta taxa de juros (HITOMI et al., 1996, p. 197-198). Apesar de o Japão ter adquirido controle de algumas regiões da China e da Coréia, o governo não conseguiu indenização da Rússia. Esse fato, junto com a expansão das forças armadas, o aumento das colônias e a nacionalização da linha ferroviária, dificultou a situação financeira do governo. O mantimento de altos impostos afetou a vida do povo (HITOMI et al., 1996, p.198-199).

Na véspera da Primeira Guerra Mundial, a economia japonesa estava à beira da falência, com dificuldades até para pagar os juros da dívida externa (NARIAI, 1999, p. 19). 
Porém, com o início da Primeira Guerra Mundial, o país passou, entre 1915 até 1918, por uma fase de boom econômico motivada pelo aumento de demanda dos bens estratégicos exigidos pelas Forças Aliadas, e pela exportação exclusiva de tecidos e de materiais diversos para o mercado asiático. Enquanto os países europeus perdiam sua capacidade de exportação, o Japão conseguia vender esses produtos para o mercado.

Nesse período, o Japão transformou-se de país devedor em credor, alcançando um grande progresso da indústria pesada. Ao contrário, o crescimento da indústria leve era moroso. A diferença salarial entre as duas indústrias tornava-se cada vez maior, formando uma "estrutura dupla": de um lado, a indústria pesada, constituída por grandes empresas, e, de outro, a indústria leve, constituída por médias e pequenas empresas.

Porém, após a Primeira Guerra Mundial, o preço do arroz subiu rapidamente, dificultando a vida cotidiana do povo. Em 1918, houve a Revolta do Arroz, na Província de Toyama, uma manifestação das mulheres, donas de casa, contra o alto preço do arroz, que logo se espalhou pelo país inteiro (HITOMI et al., 1996, p. 223).

Até o final da guerra, o Japão concluiu seu processo de industrialização. Contudo, a partir dessa época, a situação socioeconômica, influenciada pelos variados fatores internos e externos, tornou-se instável, o que acabou permitindo o autoritarismo das forças armadas. Nos anos 1920, a economia japonesa, mal auxiliada pelas medidas governamentais, vacilava de uma crise a outra, prejudicada ainda mais pelo Grande Terremoto de Kantô, ${ }^{11}$ que causou sérios prejuízos. Porém, o problema econômico tornou-se ainda mais sério após a crise mundial em 1929 (NARIAI, 1999, p. 21).

Em setembro de 1923, com o Grande Terremoto de Kantô, a riqueza acumulada

${ }^{11} \mathrm{O}$ chamado Grande Terremoto de Kantô, que atingiu principalmente a região de Tóquio e Yokohama, de magnitude 7.9 na escala Richter, em setembro de 1923, causou um desastre na economia japonesa. O número total de mortos atingiu a casa de 100 mil pessoas, e o de desaparecidos, 40 mil. 
durante a Primeira Guerra Mundial foi perdida, e a recessão se agravou.

Em 1930, o governo da época tentou o reinício da exportação de ouro e o incentivo a uma política deflacionária, com o objetivo de reconstruir a economia japonesa. Contudo, essas medidas culminaram numa séria recessão e na saída de grande quantidade de ouro, impedindo o atingimento desta meta, além de coincidir com a crise mundial, que havia se iniciado nos EUA, em 1929, causando o Pânico de Showa, em 1930 e 1931. Os preços caíram rapidamente, forçando a redução das horas de funcionamento nas fábricas, levando-as à falência. O número de desempregados aumentou, forçando as pessoas a voltarem da área urbana para a rural (NARIAI, 1999, p. 22).

Em paralelo ao Pânico de Showa acontecia a crise na área rural. Numa situação economicamente difícil, os preços das sedas cruas e do bicho-da-seda caíram bruscamente, e a boa colheita em 1930 resultou na queda do preço do arroz.

Em 1931, registraram-se graves prejuízos pela onda de frio na região nordeste (a mais pobre do país na época, ao lado de Okinawa), resultando em péssima colheita. Existe até um cálculo segundo o qual as dívidas dos homens do campo em 1932 alcançavam 114\% de suas receitas (SBCJ, 1992, p.141-142).

Nesta região, era corriqueira a tragédia de crianças subnutridas ou de filhas vendidas para prostíbulos para liquidar as dívidas dos pais. Não eram raros casos de suicídios de famílias inteiras ou de prefeituras que não tinham dinheiro para pagar salários de funcionários (SBCJ, 1992, p. 141-142).

diante da crescente crise socioeconômica que o regime democrático não conseguia solucionar, forças direitistas e pró-fascistas crescem a passos largos. É adotada uma política de militarização intensiva (...) a economia japonesa se desorganiza, produzindo centenas de milhares de desempregados. Se se incluir os jovens que nas zonas rurais permaneciam subempregados ou sem emprego, o total dos sem-trabalho chegava a mais de 3 milhões (SBCJ, 1992, p.141-142).

Ao longo dos anos 1930, as despesas militares no orçamento governamental aumentaram. O Japão, tentando superar as dificuldades econômicas através da colonização da 
China, ocupou a região nordeste chinesa em 1931, denominou-a Manchu-kuo, e tornou-a país independente em 1932. Em 1937, com o incidente da Ponte de Marco Polo, ${ }^{12}$ os dois países entraram em guerra, a Segunda Guerra Sino-japonesa (NARIAI, 1999, p. 24). Com o início desta guerra, o controle da economia pelo governo japonês foi sendo reforçado em várias áreas, como indústria, comércio e finança (NARIAI, 1999, p. 24-27).

No decorrer da Segunda Guerra Sino-japonesa, os países das Forças Aliadas (principalmente os Estados Unidos e a Inglaterra) opuseram-se fortemente à invasão da China pelo Japão, pressionando este país a abandonar sua política expansionista. O Japão reagiu, aliando-se com a Alemanha e a Itália e entrando em guerra contra as Forças Aliadas. Após desgastar todas as potências militares e civis, o país foi forçado a aceitar a proposta de Declaração de Potsdam, ${ }^{13}$ que o obrigou à rendição total (HITOMI et al., 1996, p. 246-261).

\subsubsection{Emigração para a região asiática}

Vale ressaltar aqui a presença da emigração japonesa para a região nordeste chinesa. Após a colonização dessa região e até o fim da Segunda Guerra Mundial, o Japão promoveu a emigração do seu povo para o Manchu-kuo. Como já visto acima, a situação da área rural japonesa na época estava em crise e, assim, o governo japonês tentou salvar esses agricultores colocando em ação a emigração destes e, ao mesmo tempo, objetivando garantir a defesa territorial contra a União Soviética, na região fronteiriça com o Manchu-kuo. O primeiro projeto da emigração, realizado em 1932, compreendeu os emigrantes reservistas/veteranos,

\footnotetext{
12 Incidente da Ponte de Marco Polo: a batalha entre o nacional revolucionário exército da República da China e o exército imperial do Japão, que marcou o início da Segunda Guerra Sino-Japonesa.

13 Declaração de Potsdam: documento que definiu os termos da rendição do Japão, conforme acordo na Conferência de Potsdam. A declaração estipulava que se o Japão não se rendesse, submeter-se-ia à "pronta e total destruição".
} 
que se dirigiram, armados ao Manch-kuo. O número total dos emigrantes, no fim da guerra, somou 270 mil pessoas (HITOMI et al., 1996, p. 247).

A presença desses emigrantes junto com os soldados japoneses tornou-se um grande problema no fim da guerra. No momento em que o país perdeu a guerra, estima-se que o número de japoneses civis e de soldados residentes na Ásia somavam, respectivamente, 3 milhões e 500 mil pessoas. Entre esses civis (1 milhão e 900 mil na China, e 1 milhão e 600 mil na região sul da Ásia), o regresso dos que estavam na área ocupada pelos exércitos americano e inglês foi relativamente fácil, e a maioria regressou até o final de 1947. Porém, o regresso dos que estavam na área ocupada pela União Soviética e na China se estendeu até 1957, deixando ainda problemas, como o dos órfãos e das mulheres japoneses abandonados. A maiaoria dos soldados regressou até 1949, porém, aproximadamente 570 mil deles foram levados à força para a União Soviética, e para de lá regressar o processo se arrastou por mais de dez anos. Estima-se que, dentre eles, quase 60 mil soldados morreram por causa dos pesados trabalhos forçados (HITOMI et al., 1996, p. 269).

\subsection{Rápida recuperação econômica no período pós-guerra}

\subsubsection{Recuperação e o ressurgimento econômico do Japão}

No dia 15 de agosto de 1945, quando da derrota na Segunda Guerra Mundial, o Japão estava devastado em quase todos os sentidos. No aspecto político, o país estava prestes a ser ocupado pelas Forças Aliadas (Estados Unidos, Inglaterra, França, União Soviética, China, etc.). A economia estava assolada. Durante a guerra, houvera suspensão na importação de vários produtos, o que impossibilitou a continuidade da produção industrial. A intensiva 
incursão inimiga na aérea japonesa havia destruído casas e estabelecimentos destinados à produção, e, com a derrota na guerra, o melhor cliente da economia japonesa, as forças armadas, desapareceu. A perda sofrida pelo Japão equivalia, aproximadamente, a $20 \%$ dos bens que o país possuía antes da guerra (NARIAI, 1999, p. 28). Além da presença de quase 7 milhões de ex-soldados e migrantes retornados da região asiática, a população era então $15 \%$ maior que a de 1935 (NARIAI, 1999, p. 28), agravando ainda mais a insegurança social.

A partir de 1945, até 1952, o país passou a ser ocupado pelo comando das tropas das Forças Aliadas, instalando-se ali o Quartel-general do Comando Supremo das Forças Aliadas (General Headquarters of Supreme Commander for Allied Powers), sua instituição de ordem superior. As medidas administrativas eram tomadas pelo governo japonês de acordo com as instruções e ordens do comandante-geral, general Douglas MacArthur. As mudanças ocorridas nessa época causaram grande impacto, como a Restauração Meiji, que acabou por levar o país à desmilitarização, à democratização e à reforma agrária (HITOMI et al., 1996, p. 265-268).

A situação instável da economia japonesa logo após a guerra, caracterizada pela alta inflação e pela absoluta falta de emprego, começou a apresentar melhora com a aplicação de uma série de medidas definidas em um plano projetado pelo consultor econômico do Supremo Comando das Forças Aliadas, Joseph Dodge, que visava à estabilização econômica. Este plano, conhecido como Dodge Line, impunha uma série de medidas anti-inflacionárias, objetivando equilibrar as finanças e a estabilização monetária. A fixação da taxa de câmbio (1 dólar americano = 360 ienes) foi definida nesse período (HITOMI et al., 1996, p. 269).

A fim de aplicar tais medidas, o governo japonês adotou uma política de rígido equilíbrio das finanças no ano fiscal de 1949 e, como consequência, a economia japonesa saiu 
da inflação e caiu numa deflação, ${ }^{14}$ causando falência principalmente nas áreas de produção e aumento de desempregados. Calcula-se que o número de desempregados surgidos durante o período compreendido entre a chegada de Dodge no Japão (fevereiro de 1949) até março de 1950, tenha atingido mais de 510 mil (YAMAZAKI, 2004, p. 227).

O mais importante fator para a recuperação econômica no período pós-guerra deu-se durante a Guerra de Coreia (1950-1953), quando as forças armadas americanas encomendaram às empresas japonesas o reparo de armas e de carros, a produção de bombas e outros artefatos, encomendas estas denominadas "aquisição especial", que causaram um boom na economia japonesa e serviram de impulso para a recuperação dos prejuízos da guerra. Assim, no início dos anos 1950 a economia japonesa já se encontrava quase no final do processo de sua reestruturação (NARIAI, 1999, p. 32).

A pergunta sobre "quais os fatores possibilitaram uma recuperação tão rápida" encontra resposta no avanço da tecnologia que havia sido realizado através da produção da indústria bélica durante a guerra; na renúncia ao armamento após a guerra, que possibilitou a convergência dos recursos para a produção civil; nas baixas despesas militares, que permitiram a redução de impostos, facilitando o acúmulo de capitais privados; na forte assistência do governo concedida às empresas através dos bancos (NARIAI, 1999, p. 32); na mão de obra barata e abundante.

Em 1951, através do Tratado de São Francisco, ${ }^{15}$ o Japão recuperou sua autonomia. Simultaneamente, o país assinou o Tratado de Cooperação Mútua e Seguridade entre os

14 Deflação: redução da demanda global por mercadorias e serviços resultante de medidas de política econômica, em geral visando reduzir a inflação (Novo dicionário da língua portuguesa, 2004).

15 Tratado de São Francisco: tratado de paz entre as forças aliadas e o Japão, assinado oficialmente por 49 nações (inclusive o Japão), em 8 de setembro de 1951, em São Francisco, na Califórnia, cuja entrada em vigor deu-se em 28 de abril de 1952. Outro documento assumido e assinado ao mesmo tempo, o Tratado de Cooperação Mútua e Seguridade entre os Estados Unidos e o Japão, assegurou a permanência das forças armadas estadunidenses até os dias de hoje. 
Estados Unidos e o Japão (Treaty of Mutual Cooperation and Security between the United States and Japan), o que assegurou a ausência de conflitos militares com o exterior e o progresso econômico na fase seguinte (HITOMI et al., 1996, p. 271-272).

A partir de 1955, a economia japonesa, apoiada pelo progresso tecnológico e pela economia mundial estável e favorável, entrou num período de crescimento acelerado. Por mais de des anos, a taxa média de crescimento anual registrou índices acima dos 10\%. Em 1956, o Livro Branco da Economia, uma espécie de relatório, editado pela Secretaria de Planejamento Econômico do governo japonês, declarou que “o período (da recuperação) pós-guerra já havia passado”. Em 1968, o Japão atingiu o segundo lugar entre os países desenvolvidos, em termos do PIB, perdendo apenas para os EUA. E foi assim que o Japão começou a se tornar um dos países mais desenvolvidos e ricos no mundo (NARIAI, 1999, p. 35).

Simultaneamente, com o crescimento econômico do país, a partir da segunda metade dos anos 1950, a vida cotidiana dos japoneses também mudou. Essa mudança, acompanhada de vários fenômenos, como: produção e consumo em massa; maior conveniência e variedade de opções de vestuário, de alimentos e de moradias; posse de bens de consumo duráveis (televisão, máquina de lavar roupa e geladeira, chamados de "três tesouros", ${ }^{16}$ carros, etc.), foi chamada de "Revolução de Consumo". Nesse mesmo período, a maioria (80-90\%) dos japoneses passou a ter consciência de pertencer à classe média (HITOMI et al., 1996, p. 281).

O período de crescimento acelerado terminou com a adoção da taxa flutuante de câmbio pelos EUA e com o primeiro Choque do Petróleo, em 1973. O país sofreu a falta deste produto e uma inflação galopante assolou o arquipélago, registrando, pela primeira vez após a guerra, em 1974, a taxa negativa de crescimento econômico (NARIAI, 1999, p. 45-46). A economia japonesa entrou em situação de "estagflação", isto é, a coexistência de recessão e de

16 Associando-se aos três tesouros necessários para a posse do imperador: espelho, espada e pedra preciosa. 
inflação (YAMAZAKI, 2004, p. 297).

O Japão conseguiu superar aquela situação crítica relativamente mais cedo que os outros países desenvolvidos por meio de várias medidas, como o uso controlado da energia e a mudança de estrutura industrial. Algumas áreas industriais, como a de aço e de construção naval que dependiam grandemente de energia, principalmente de petróleo, diminuíram a velocidade de crescimento, entrando numa estagnação estruturada (YAMAZAKI, 2004, p. 297; NARIAI, 1999, p.45-46), enquanto as outras indústrias, que exigiam menos energia para a produção, principalmente as de montagem (carros, produtos elétricos, semicondutores, etc.), foram crescendo. Os produtores destas áreas, apresentando vantagem de qualidade e preço, aumentaram a exportação, tornatam-se as principais áreas competitivas da indústria japonesa pós-guerra, trazendo grandes lucros (YAMAZAKI, 2004, p. 295).

O rápido desenvolvimento industrial pós-guerra foi liderado principalmente por ramos industriais de montagem (como as indústrias automobilísticas e eletrônicas). A indústria automobilística japonesa, durante o período compreendido entre 1955 e 1985, atuou como arrimo da economia japonesa, e, em 1980, fez com que o Japão ultrapassasse os Estados Unidos como maior produtor de veículos automotivos do mundo.

A evolução do número de unidades produzidas se deu pelos seguintes números: 70 mil unidades (1955); 480 mil unidades (1960); 1.188 mil unidades (1965); 5.290 mil unidades (1970); 6.940 mil unidades (1975); 11.040 mil unidades (1980); 12.270 mil unidades (1985). Por outro lado, a porcentagem de unidades exportadas em relação ao número total de unidades produzidas assim evoluiu: 1.000 unidades/2\% (1955); 190 mil unidades/10\% (1965); 2.680 mil unidades/21\% (1975); 6.730 mil unidades/55\% (1985).

A indústria automobilística passou a ocupar crescente e importante lugar na economia japonesa (mais de 10\% do PIB), tendo atuado como uma das locomotivas que impulsionaram a 
fase de crescimento econômico acelerado do país. Além disso, exerceu influência sobre o crescimento nos setores de materiais, peças e componentes (YAMAZAKI, 2004, p. 344-5).

Além desses fatores, houve também mudanças tecnológicas e organizacionais que alteraram profundamente o processo produtivo nessas indústrias. Principalmente, o sistema de subcontratação teve grande significado. As maiores empresas constituíram-se no topo de uma imensa rede de empresas subcontratadas para produzir peças, componentes e serviços necessários a seus projetos econômicos. Geralmente, o sistema de subcontratação, bastante difundido no país, apresentou-se sob uma estrutura piramidal, na qual as empresas terceirizadas encontravam-se em camadas organicamente articuladas a uma empresa principal, a qual, por sua vez, destinava-se a suprir a grande empresa industrial (YAMAZAKI, 2004, p. 304-5).

\section{3. "Economia de Bolha" e a escassez de mão de obra}

Nas décadas seguintes à Segunda Guerra Mundial, o Japão implementou uma política incentivadora da poupança. De um lado, com mais dinheiro nos bancos, tornaram-se mais fáceis os financiamentos e créditos para as empresas. Por outro, o iene, na época mais baixo em comparação com as moedas estrangeiras, possibilitou maiores e mais fáceis os investimentos para as empresas japonesas em relação às suas concorrentes estrangeiras, reduzindo o preço de produtos japoneses e trazendo maior superávit comercial e, ainda, tornando mais lucrativas suas ações nas Bolsas de Valores.

Na década de 1980, de acordo com o contexto histórico anteriormente explicitado, o fundamento da economia japonesa residia na exportação. Com o crescimento da exportação, apoiado pelo câmbio favorável, conflitos surgiram com outros países, principalmente com os 
EUA. Em 1985, foi realizado o Acordo de Plaza, ${ }^{17}$ que causou a elevação da taxa do iene. Como consequência desta elevação, o crescimento econômico teve sua velocidade reduzida, diminuindo a exportação e causando a "Depressão do Alto Iene".

O Banco do Japão tentou a recuperação do crescimento reduzindo a taxa de juros. Seus financiamentos tornaram-se mais fáceis, e os capitais se tornaram abundantes, investidos em ações e imóveis. Consequentemente, elevaram-se os valores das ações e dos terrenos, iniciando-se assim, na segunda metade dos anos 1980, a "Economia de Bolha", um período de prosperidade econômica que durou de 1986 até 1991 (NARIAI, 1999, p. 59).

Nos anos 1980, o balanço comercial totalmente favorável para o Japão ofereceu excessivos lucros para as empresas, levando muitas delas a mudarem a maneira de aquisição de capital de investimento. Até essa época dependentes de empréstimos de bancos, elas passaram então a investir os lucros abundantes diretamente no mercado financeiro. Pela falta de prática e conhecimento, muitos desses investimentos diretos não deram resultados positivos, causando acúmulo de dívidas nessas empresas (YAMAZAKI, 2004, p. 365). Diante deste cenário, e para atender a essas mudanças (investimentos diretos no mercado financeiro e tendência empresarial da não dependência de empréstimos bancários), os bancos prescisavam encontrar novos destinos para seus empréstimos. Consequentemente, acabaram optando pelos empréstimos de alto risco, mas sem realizar as devidas pesquisas dos históricos dos tomadores, o que acabou culminando no acúmulo de créditos irrecuperáveis na década seguinte (YAMAZAKI, 2004, p. 365).

A riqueza produzida pela elevação dos preços das ações e dos terrenos intensificou

\footnotetext{
17 Acordo de Plaza: realizado na reunião de Ministros da Economia dos cinco países mais importantes do FMI Fundo Monetário Internacional (EUA, Japão, França, Alemanhã e Inglaterra), cuja pauta visava a discussão sobre intervenções para baixa da cotação de dólar, com o objetivo de salvar os EUA, que haviam se tornado país devedor por causa do crescente déficit comercial. No Japão, a consequência do acordo foi a elevação do iene.
} 
significativamente o consumo em geral. O PIB aumentou mais de 5\% por ano. As empresas começaram a ter dificuldades de recrutamento, enquanto, para os trabalhadores, o leque de opções aumentou para a escolha de um emprego (principalmente para os recém-formados), prevalecendo, portanto, seu livre-arbítrio nessa escolha.

Esse boom terminou em 1991, e o Japão entrou no período de uma das mais longas recessões, que perdurou por mais de dez anos (NARIAI, 1999, p. 59). Mas, mesmo nesse período de depressão (aproximadamente de 1991 até 2001), a exportação japonesa continuou superavitário. O que sugere que o sistema produtivo japonês basicamente continuou a ser sólido, embora alguns problemas estivessem acontecendo no sistema financeiro (YAMAZAKI, 2004, p. 365-6).

\subsection{Mercado de trabalho japonês}

O mercado de trabalho japonês costumava ser caracterizado pelo seu sistema empregatício. Em 1973, a OCDE (Organização para Cooperação e Desenvolvimento Econômico) descreveu as características a seguir como o "modelo puro", que representava o sistema empregatício japonês: emprego vitalício, salário por antiguidade, sindicato intraempresarial (YAMAZAKI, 2004, p. 310-311). Apesar de este sistema ter passado por mudanças, ainda é suficientemente importante para ser explicitado aqui.

A maioria dos dirigentes das grandes empresas japonesas é de "endógenos" ou "autóctones", ou seja, pessoas admitidas imediatamente após graduarem-se nas universidades, que galgaram posições dentro da própria empresa. Por outro lado, os sindicatos trabalhistas não se dividem por categorias ocupacionais, como costuma ocorrer na Europa e nos EUA, mas congregam, uniformemente, tanto os "blue collars" (trabalhadores monofuncionais) quanto os 
"white collars" (trabalhadores intelectuais) na mesma empresa. Assim, sua função passa a adquirir um caráter mais conciliatório que litigioso, obtendo, como resultado, o fomento do paternalismo empregatício e o esquema coletivista ou colegiado de administração empresarial (YAMAZAKI, 2004, p. 310-311).

Neste esquema, o empresário dirige-se aos funcionários com uma atitude de benevolência paternalista, enquanto os funcionários intensificam seu sentimento de fidelidade à empresa; os interesses coletivos prevalecem sobre os individuais, mas, em termos de relações humanas, prepondera o espírito da ajuda mútua. Baseado na estrutura tradicional da sociedade japonesa, ao mesmo tempo este esquema se aprimorou e se fortaleceu durante o processo de modernização da indústria japonesa e de desenvolvimento das empresas após a Restauração Meiji (1868). Esses fatores se consolidaram num só fôlego durante a fase de rápido crescimento econômico do Japão, particularmente nas grandes empresas do setor manufatureiro (a relação trabalhista no estilo japonês se desenvolveu também no setor de transporte para distribuição de bens, e entre as pequenas e médias empresas, mas o grau de consolidação não foi tão manifesto como nas grandes empresas do setor manufatureiro, devido à fluidez da mão de obra e outros fatores congêneres) (YAMAZAKI, 2004, p. 310-311).

O termo "emprego vitalício" não significa que a relação persista literalmente durante toda a vida do trabalhador. Tentando uma definição mais precisa, pode-se dizer que é o costume que garante a continuidade do emprego até a idade de aposentadoria compulsória, não havendo demissão sem justa causa; portanto, uma relação empregatícia de longa duração (YAMAZAKI, 2004, p. 310-311).

Este sistema foi inicialmente criado com a finalidade de evitar a diáspora da mão de obra qualificada na fase incipiente da indústria japonesa, nas eras Meiji (1868-1912) e Taishô (1912-1925), mas desempenhou um papel preponderante no desenvolvimento das empresas 
japonesas após a Segunda Guerra Mundial (YAMAZAKI, 2004, p. 310-311).

Os funcionários devotam-se em prol da empresa, à qual confiam sua própria sorte, incluindo-se o fato de não se recusarem a fazer horas extras. Por outro lado, a empresa procura corresponder a tal fidelidade com recompensas de várias formas, sem se limitar ao âmbito salarial. Os generosos benefícios marginais, que abrangem moradia para os funcionários casados, alojamentos para os solteiros, colônias de férias para os funcionários e familiares, etc., que se difundiram durante a fase das altas taxas de crescimento da economia japonesa, tinham como premissa as relações empregatícias de longo prazo. As empresas dispensavam atenção inclusive à situação dos familiares dos funcionários, contexto no qual generalizou-se a prática que consistia no auxílio-família aos funcionários com cônjuges e filhos. Aos funcionários solteiros enviados ao exterior para permanência prolongada, chegou-se a criar o sistema de retorno temporário ao Japão para a busca de cônjuge. Neste caso, o interessado tinha direito a férias remuneradas e, em alguns casos, a empresa empregadora arcava com os custos da viagem (YAMAZAKI, 2004, p. 310-311).

Nesse contexto, foi adotado um sistema salarial baseado na antiguidade, esteado no número de anos de serviço prestados à empresa e na idade do funcionário que, juntamente com o sistema de garantia de emprego por períodos prolongados, formam as duas faces de uma mesma moeda. De um lado, caso o número de funcionários que se aposentam, por haver atingido a idade compulsória, seja igual ao de jovens funcionários recém-admitidos, a empresa estará habilitada a canalizar a diferença salarial entre este novatos e os veteranos aposentados, a fim de conceder o aumento salarial periódico aos funcionários na ativa sem nenhum ônus especial à empresa. De outro, no sistema salarial baseado na antiguidade, o conteúdo do serviço prestado pelo funcionário tende a ser relegado a um segundo plano, o que implica o risco de tirar a motivação dos funcionários capacitados. Entretanto, como na fase das altas 
taxas de crescimento da economia japonesa as margens de aumento salarial eram grandes, graças ao bom desempenho das empresas, os deméritos do sistema salarial baseado na antiguidade não ficavam muito evidentes (YAMAZAKI, 2004, p. 310-311).

Como já comentado, as funções dos sindicatos trabalhistas no sistema empregatício japonês possuem um característica mais conciliatória. Com a entrada em vigor da Lei dos Sindicatos Trabalhistas em 1946, as agremiações operárias foram sucessivamente criadas em todo o território japonês. A maioria delas tomou a forma de organismos intraempresariais, que abrangiam de maneira uniforme todos os funcionários pertencentes a uma mesma empresa, um recurso de efeito imediato que visava resguardar os interesses dos trabalhadores expostos à confusão reinante após a Segunda Guerra Mundial. Em vista de sua idiossincrasia como sindicato intraempresarial, entretanto, a classe trabalhista e a classe empresarial passaram a compartilhar um mesmo barco, e a postura do sindicato ficou ambígua (YAMAZAKI, 2004, p. $311)$.

Para sanar as desvantagens dos sindicatos intraempresariais, existe uma "luta anual" dos empregados pela subida de salário, o Shuntô, uma ofensiva trabalhista primaveril (primavera do Japão, no mês de maio), assim chamada por ter lugar anualmente na primavera, que corresponde ao início do exercício fiscal japonês. É uma rodada de negociações mantida entre as classes trabalhista e empresarial. De um lado estão os sindicatos trabalhistas, estruturados por setor econômico e orientados pelo organismo centralizador dos sindicatos trabalhistas, enquanto, do outro lado, estão os organismos representativos dos empresários (YAMAZAKI, 2004, p. 311).

O rápido crescimento econômico (aproximadamente 1955-1965) causou também uma mudança substancial no mercado de trabalho. Até essa época, o Japão costumava ter uma vasta reserva de mão de obra, constituída principalmente pelos jovens pertencentes às famílias de 
agricultores que, pouco a pouco, migraram para as cidades, atendendo à mão de obra necessária para as empresas e indústrias. Contudo, na medida em que a economia ia crescendo, subitamente o país passou a sofrer de escassez de trabalhadores.

No final dos anos 1950 até o início dos 1960, houve uma forte procura de mão de obra, registrando-se aumento anual da população de trabalhadores de mais de 1 milhão de pessoas. Como havia reserva de potencial mão de obra na área rural, até próximo 1959 o equilíbrio de procura e de oferta de trabalhadores foi mantido. Porém, durante o boom de 1960-1961, mesmo na área rural começou a ser sentida a falta de trabalhadores. A escassez de mão de obra causou elevação do valor de salários nas pequenas e médias empresas, o que contribuiu para a diminuição da diferença salarial entre as pequenas, médias e grandes empresas (YAMAZAKI, 2004, p.295).

O ano de 1955, considerado o ponto inicial do período de crescimento acerelado, foi também o que deu início ao arranjo coletivo de emprego. Na segunda metade dos anos 1950, mais de $70 \%$ dos recém-formados no ensino fundamental preenchiam vagas nas empresas de médio e pequeno portes (menos de 99 empregados) pela intermediação das escolas. Contratação de jovens trabalhadores era um princípio básico das empresas de pequeno e médio portes.

No sistema de escalonamento segundo o tempo de serviço, pode-se contratar mais de um trabalhador jovem com o custo de um trabalhador de meia-idade, com o benefício a mais de ainda poder contar com a aptidão dos jovens de se adaptarem às novas tecnologias.

Posteriormente, as empresas de grande porte também começaram a contratar um grande número de jovens. Em 1968, a porcentagem dos trabalhadores nas empresas de pequeno e médio portes diminuiu para um terço do número total. Assim, a escassez de mão de obra surgiu nessas empresas e, posteriormente, nos anos 1960, nas empresas de grande porte. 
Essa tendência foi intensificada pelo crescente ingresso de jovens no ensino médio.

No decorrer do período de crescimento acelerado (1955-1965), a organização básica do mercado de trabalho mudou, de abundância de mão de obra, para escassez, influenciando na política de administração trabalhista das empresas.

Operários temporários, considerados como buffer $^{18}$ da mudança econômica, passaram a ser contratados efetivamente. A presença feminina nas empresas ficou mais visível. Os salários da população jovem aumentaram, diminuindo diferenças salariais determinadas pela idade e pelas escalas empresariais (YAMAZAKI, 2004, p. 295).

\subsubsection{Dualismo entre empresas japonesas}

$\mathrm{Na}$ indústria japonesa, existem significativas diferenças entre as grandes empresas e as de pequeno e médio portes em termos de administração trabalhista (condições de trabalhadores, salários). Esse dualismo foi formado através da história econômica japonesa. Os dois tipos de empresa têm uma relação complexa, representada pelo sistema produtivo denominado Toyotismo.

Comentaremos a seguir este processo histórico causador da formação deste dualismo empresarial.

Com a eclosão da Primeira Guerra Mundial, em 1914, a economia japonesa experimentou um boom sem predendente, que mudou imensamente sua estrutura. Com o surgimento de oportunidades, de comércio exterior e de aquisição de lucros, causadas pela guerra, em algumas áreas industriais deu-se uma grande onda de aparecimento de novas empresas. Principalmente a interrupção de importação causada pela Guerra influenciou a

\footnotetext{
18 Buffer: para-choque.
} 
indústria pesada (indústrias química, mecânica, elétrica, metal, etc.), provocando o nascimento tanto das grandes empresas como das de pequeno e médio portes.

Esse boom causado pela Guerra chegou ao fim na crise que aconteceu em 1920 e, nessa década, a economia japonesa experimentou um período de depressão. No período pós-guerra (Primeira Guerra Mundial), pelas influências da crise mundial, a economia japonesa defrontou-se com sua situação mais crítica, chamada de "Pânico de Showa" (1930) (YAMAZAKI, 2004, p. 162-163).

Nos anos 1930, muitas das empresas de pequeno e médio porte foram inseridas no sistema piramidal de produção. Neste sistema, "as maiores empresas constituíram-se no topo de uma imensa rede de empresas subcontratadas para produzirem peças, componentes e serviços necessários a seus projetos econômicos" (Kawamura, 2001, p.106). Aqui, "as empresas terceirizadas encontram-se em camadas organicamente articuladas a ... empresa principal, a qual, por sua vez, destina-se a suprir a grande empresa industrial" (Kawamura, 2001, p.106). Esse sistema de subcontratação proliferou-se ainda mais nas principais indústrias no período após a Segunda Guerra Mundial (YAMAZAKI, 2004, p. 162-163).

Durante a Primeira e a Segunda Guerras Mundiais, as maiores empresas modernizavam-se cada vez mais, e as diferenças em relação às menores foram ficando maiores. Entre as principais destas diferenças destacam-se: condições da mão de obra, uns mais estáveis, outros menos; diferenciação salarial; tecnologias e equipamentos diversificados, conforme o tamanho da empresa, etc. (YAMAZAKI, 2004, p. 162-163).

O dualismo persistiu também no período pós-guerra (Segunda Guerra Mundial). O Livro Branco da Economia de 1957 observou a presença desta estrutura dual.

Após a Segunda Guerra Mundial, de um lado, diante de uma tendência de abundância de mão de obra, um grande número de empresas de pequeno e médio portes, não modernizadas 
e com baixo salário, promoveram uma concorrência feroz entre si. Por outro, as grandes acumularam capitais, explorando as empresas menores empresas e seus trabalhadores contratados com baixo salário. Assim, surgiram enormes diferenças salariais e de produtividade. No período de crescimento acelerado (aproximadamente 1955-1965) deu-se o emprego de toda a população economicamente ativa e um aumento substancial de salários. Com a intensificação da falta de mão de obra na segunda metade dos anos 1960, muitas das empresas menores, cuja existência dependia de mão de obra barata, acabaram desaparecendo. Assim, a "estrutura dual" acima citada tendeu a se minimizar (YAMAZAKI, 2004, p. $162-163)$.

O aumento de salários e a falta de mão de obra no período de crescimento acelerado incentivaram o investimento em altas tecnologias nas empresas menores. As maiores constituíram uma imensa rede de produção, inserindo aquelas como subcontratadas. Principalmente nas áreas de montagem (assembler), como as indústrias automobilística e mecânica, a organização de empresas menores com capacidade produtiva especializada era necessária para a melhoria da qualidade de produtos e para a redução do custo de produção (um dos fatores do sistema produtivo chamado Toyotismo, que será esclarecido na seção 3.4.2. As empresas menores também se beneficiaram, por exemplo, com a transferência de tecnologia da empresa maior ou com apoios na promoção de venda ou nos financiamentos (YAMAZAKI, 2004, p. 162-163).

Além disso, muitas dessas empresas subcontratadas procuraram localizar-se ao redor das empresas contratantes. Assim, formava-se, nessas localidades, uma cidade desenvolvida (company town) no entorno das grandes empresas, como aconteceu na cidade de Toyota (cujo nome teve origem justamente pela chegada da empresa homônima), na Província de Aichi, pela presença da Toyota Motor Corporation, a mundialmente conhecida produtora de 
automóveis. Além deste fenômeno da company town nas grandes cidades, dois fatores incentivaram a formação de regiões com maior concentração das empresas de pequeno e médio portes em várias áreas: a existência de grande população à procura de produtos de consumo e a proximidade do local para sua aquisição (YAMAZAKI, 2004, p. 162-163).

Uma das características do dualismo entre empresas japonesas foi a organização sistemática, por uma empresa maior, de empresas de pequeno e médio portes (YAMAZAKI, 2004, p. 162-3). Citando o caso da indústria automobilística, as grandes empresas japonesas adotaram uma estratégia de "semi-integração piramidal", terceirizando as produções de materiais e de peças junto às empresas de menor porte, e organizando essas menores empresas como um grupo, subordinado à empresa maior, que ocupa o topo da pirâmide (frequentemente, as menores empresas são ligadas a essa empresa maior em termos de capital social, como subcontratadas). Apenas como exemplo, cita-se o caso dos EUA. Diferentemente do caso das empresas japonesas, a indústria automobilística norte-americana adotou uma "integração piramidal”, isto é, a produção de materiais e de peças no interior da própria empresa (YAMAZAKI, 2004, p. 296). 


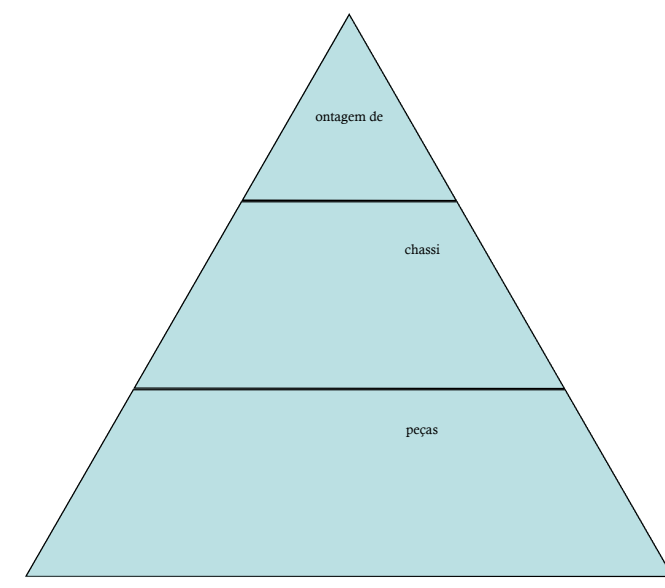

Gráfico 3 - EUA “integração piramidal”

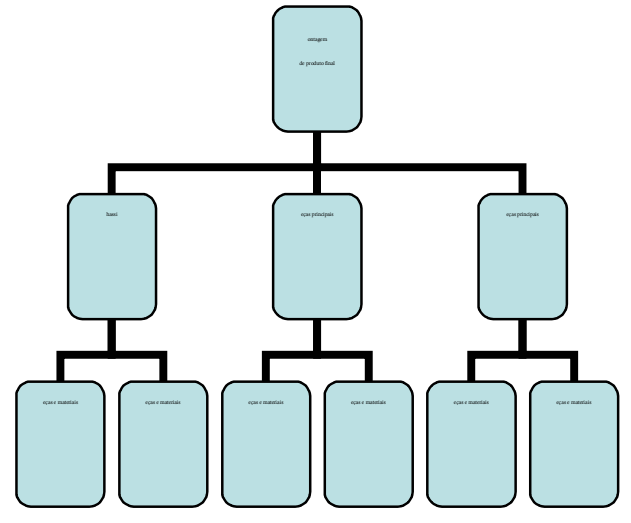

Gráfico 4 - JAPÃO “semi-integração piramidal”

Por exemplo, a Toyota organiza seus produtores subcontratados separando-os como "produtor com gráficos emprestados" e "produtor com gráficos aprovados". No primeiro grupo, a produção se dá conforme um gráfico feito pela Toyota, enquando no segundo, os próprios produtores criam gráficos, apresentando-os para a Toyota e, se aprovados, pasam à produção das peças. As produtoras do segundo grupo têm capacidade de inovação e de planejamento de produtos, muitas vezes tendo seus próprios produtores subcontratados. Assim, foi construído um sistema produtivo interdependente e flexível, baseando-se na organização estratificada de produtores mutuamente relacionados (YAMAZAKI, 2004, p. 296).

Nos anos 1970, num cenário de intensificação de concorrência internacional, a exigência das grandes empresas por redução de custo das menores era constante. Na tentativa de atender a essas exigências, a concorrência entre as empresas menores também se intensificou, agravando a diferença entre as que conseguiram a redução de custo e as que não. As empresas subcontratadas que conseguiram vencer a concorrência procuraram diversificar seus parceiros comerciais, buscando assim não depender de uma única empresa contratante. 
Algumas delas conseguiram uma posição equivalente à das grandes empresas, mediante a obtenção de tecnologias específicas e de capitais acumulados (YAMAZAKI, 2004, p. 304-305).

\subsubsection{Sistema produtivo japonês: o Toyotismo}

Após a Segunda Guerra Mundial, a Toyota Motor Corporation enfrentava um impasse que a impossibilitava de incrementar de forma substancial seus recursos humanos e financeiros. Na realidade, a mesma situação aplicava-se também a muitas empresas japonesas da época. Entretanto, com a chegada da bonança, caracterizada pelas altas taxas de crescimento econômico, muitas empresas do setor manufatureiro optaram por introduzir máquinas operatrizes especializadas de uso exclusivo, incrementar a produção e expandir a mão de obra.

Contudo, os fabricantes de veículos automotivos se encontravam atrasados no âmbito internacional, e limitavam-se a vender no mercado interno. Sob tais circunstâncias, mesmo que o mercado interno crescesse, não havia margens para construir linhas de montagem exclusivas para produzir um único modelo de veículo. Dessa maneira, as empresas foram forçadas a dar continuidade aos seus esforços visando baixar o ponto de equilíbrio, que determina o limiar da rentabilidade. Essa maneira de administrar os negócios passou a atrair atenção especial após a Crise do Petróleo. O estilo administrativo das empresas bem-sucedidas passou a ser difundido de forma deliberada. Como resultado, termos como kanban, que se limitavam ao uso interno da Toyota Motor Corporation, passaram a ganhar aceitação generalizada; particularmente nas empresas do setor manufatureiro, onde predominam as etapas de montagem e processamento, a ideia foi abraçada com entusiasmo (YAMAZAKI, 2004, p. 315). 
Em vista do êxito que as empresas japonesas alcançaram na década de 1980, o sistema japonês de produção industrial passou a ser alvo de atenção no exterior. Na verdade, a maior parte daquilo que à época foi propalado como o "sistema japonês de produção industrial" nada mais é que o resumo das características do sistema de produção industrial da Toyota Motor Corporation. Ele é, em suma, o sistema de produção industrial que foi criado como resultado dos esforços visando superar os obstáculos antepostos às empresas japonesas após a Segunda Guerra Mundial. Dessa maneira, hoje é um sistema comum a muitas empresas japonesas (YAMAZAKI, 2004, p. 315).

A indústria automobilística japonesa, durante as três décadas entre 1955 e 1985, atuou como arrimo da economia do Japão, resultando, em 1980, a ultrapassagem do Japão, ante os Estados Unidos, como maior produtor de veículos automotivos do mundo. A evolução do número de automóveis produzidos foi assim registrada: 70 mil unidades (1955); 480 mil unidades (1960); 1.188 mil unidades (1965); 5.290 mil unidades (1970); 6.940 mil unidades (1975); 11.040 mil unidades (1980); 12.270 mil unidades (1985). Em contrapartida, a porcentagem de automóveis exportados em relação aos produzidos assim evoluiu: 1.000 unidades/2\% (1955); 190 mil unidades/10\% (1965); 2.680 mil unidades/21\% (1975); 6.730 mil unidades/55\% (1985). A indústria automobilística passou a deter crescente peso dentro da economia japonesa (mais de $10 \%$ do PIB), tendo atuado como uma das locomotivas que impulsionaram a fase de crescimento econômico acelerado do país. Além disso, exerceu influência sobre o crescimento nos setores de materiais, peças e componentes (YAMAZAKI, 2004, p. 344-345).

Os principais fatores que impulsionaram o desenvolvimento da indústria automobilística foram: inovação ininterrupta nos produtos e na tecnologia; inovação na tecnologia de produção; relação de transações comerciais a longo prazo estabelecida entre as 
montadoras de veículos e as empresas fabricantes de peças e componentes. Este último fator, principalmente, é conhecido como importante item do sistema produtivo japonês: o “Toyotismo" (YAMAZAKI, 2004, p. 344).

O caso pioneiro do "Toyotismo" (sistema de produção industrial segundo a Toyota Motor Corporation) surgiu na linha de montagem do modelo Corolla, da Fábrica de Takaoka, da Toyota Motor Corporation (YAMAZAKI, 2004, p. 344).

Durante a Segunda Guerra Mundial, as empresas japonesas fabricantes de veículos automotivos dedicavam-se exclusivamente à produção de caminhões para o uso militar. Com o término da guerra, entretanto, deram conta da inviabilidade de se dedicar à produção em massa e à venda de um único modelo, além da inadequação de tal modelo de negócio às contingências do mercado. Assim, essas empresas passaram a produzir uma ampla variedade de modelos em pequenos lotes.

Pode-se dizer que não havia outra maneira de sobrevivência, senão garantir o volume de produção da empresa como um todo, baseando-se em um certo número de modelos. Desta forma, incrementava-se o faturamento e buscava-se a rentabilidade. Além disso, a situação que as empresas enfrentavam era bastante severa. Na época imediatamente após a guerra, as condições financeiras das empresas eram adversas, não havia recursos para investimentos de grande porte em instalações e equipamentos e, além disso, o recrutamento maciço de mão de obra era inviável. Os dissídios trabalhistas experimentados no período pós-guerra serviam também para inibir o empresariado, pois não havia condições de expandir o efetivo de forma ilimitada nas horas das necessidades e demitir em massa quando a recessão chegasse. Dentro de circunstâncias caracterizadas por uma insuficiência crônica de recursos, tanto financeiros como humanos, às empresas era exigido alcançar níveis internacionais, tanto de qualidade como de custo (YAMAZAKI, 2004, p. 314-315). 
A insuficiência de recursos financeiros impeliu a Toyota Motor Corporation, que era intrinsecamente uma empresa fabricante de veículos automotores, à modalidade operacional chamada assembler. Alguns elementos essenciais, tais como o motor, eram fabricados internamente, mas a taxa de fabricação interna era baixa em comparação com as rivais norte-americanas. A maior parte das peças e componentes era fabricada pelas empresas fornecedoras externas com as quais Toyota Motor Corporation mantinha uma relação comercial de longo prazo. Como resultado desta metodologia, deu-se a redução dos investimentos totais requeridos à Toyota Motor Corporation para a fabricação de seus veículos. A insuficiência de recursos financeiros fê-la caminhar por trajetos diferentes das rivais europeias e norte-americanas, também em relação aos investimentos em maquinarias e instalações do recinto de produção. Naturalmente investimentos foram feitos no que diz respeito a máquinas operatrizes indispensáveis, mas quanto à aquisição de máquinas operatrizes de uso exclusivo ou cativo, que serviam somente para um único modelo de veículo, foram relegadas a um plano secundário. Em vez disso, os recursos disponíveis foram investidos visando adquirir máquinas versáteis, que podiam ser aplicadas a modelos múltiplos de produtos (YAMAZAKI, 2004, p. 314-315).

No setor de estamparia das empresas automobilísticas, esse raciocínio foi implementado de forma bastante contundente. Embora nos sistemas de produção em massa do tipo usual a implantação de prensas de uso exclusivo, aplicável a um único modelo, seja o esquema mais usual, a Toyota Motor Corporation optou por introduzir prensas de tipo universal, cujas matrizes de estampagem eram trocadas em curto espaço de tempo para possibilitar a fabricação de vários modelos de veículos em uma mesma linha de produção (YAMAZAKI, 2004, p. 314-315).

Além disso, introduziram-se aprimoramentos visando minimizar o inventário 
desnecessário no processo de produção, ou seja, a implantação do "sistema just-in-time", que exige fornecimento de peças na hora exata da necessidade. Isto possibilitou implantar um esquema de produção enxuto, que requer menor volume de capital. Adicionalmente, os operários, até então fixados em afazeres específicos, foram treinados de tal maneira a estar aptos para executar diferentes tipos de tarefas de conformidade com o incremento da produção. Incrementou-se a versatilidade da mão de obra, flexibilizando assim a alocação de um efetivo reduzido. Este ponto passou a atrair as atenções como uma alternativa para superar a grande desvantagem do "Fordismo", que é a execução de tarefas simples por operários estanques (YAMAZAKI, 2004, p. 344).

Tais medidas começaram a ser introduzidas após os dissídios trabalhistas da década de 1950, mas não se pode dizer que a abordagem tenha sido sistemática nem abrangente desde o começo. A Toyota Motor Corporation começou a se empenhar de forma atuante na sistematização das empresas fornecedoras de peças e componentes a partir dos primeiros anos da década de 1960. Desde aquela época, iniciativas foram tomadas visando aprimorar os esquemas de controle interno, com foco na qualidade. Como decorrência disso, atividades de QC (Quality Control $=$ Controle de Qualidade) passaram a ser praticadas em todos os recantos do recinto de produção. Iniciativas dessa natureza foram implementadas de forma abrangente, cobrindo a totalidade da empresa, tendo este processo culminado, em 1965, com a obtenção do Prêmio Demming ${ }^{19}$ pela Toyota Motor Corporaion. Na sequência, a Toyota intensificou seu grau de entrosamento com as empresas fornecedoras, objetivando sincronizar a produção com os fabricantes de peças e componentes (YAMAZAKI, 2004, p. 314-315).

19 Prêmio Deming: estabelecido em 1950, em homenagem a W. Edward Deming, specialista em controle de qualidade norte-americano, é dado a pessoas e empresas que conseguiram um maior avanço na melhora de qualidade. 


\section{CAPÍTULO 4 - MIGRAÇÃO JAPONESA NO BRASIL}

\subsection{Origem e histórico da imigração japonesa no Brasil}

\subsubsection{Imigração japonesa nos países variados}

Ao se considerar um movimento migratório, há sempre elementos do país de origem e do país de destino, os chamados fatores de atração-repulsão (push-pull) (ROCHA-TRINIDADE, 1995, p. 76). Ao tratar da migração japonesa no Brasil, nesta seção, abordaremos os fatores de repulsão - as circunstâncias japonesas que promoveram essa migração. "Até o início do século XX, o Japão foi um país tipicamente agrícola" (NOGUEIRA, 1984, p. 31).

Em primeiro lugar, como se viu no capítulo 3, no final da era Edo (1600-1867), enquanto os agricultores ocupavam mais de $80 \%$ da população total, começaram a surgir vários problemas, como a superprodução e a baixa produtividade agrícola. No século XVIII, a presença da economia mercantil foi tomando espaço, no lugar da economia agrícola, rural e autossuficiente já existente. Essas alterações atingiram a população rural, tanto proprietários como camponeses. Embora tenha sido expressamente proibida a venda de terrenos, por causa da cobrança pesada de tributos pelos priprietários afetados pelo desenvolvimento de uma economia monetária, os camponeses foram obrigados a hipotecar ou vender parte de suas terras. Após a Restauração Meiji, a reforma tributária, que obrigou o pagamento em dinheiro em lugar de espécie, esta tendência intensificou-se. Com isso, passou a reinar uma grande miséria no campo (NOGUEIRA, 1984, p. 35). Porém, o grau de urbanização ainda não era suficiente para absorver aquelas pessoas que haviam perdido seu meio de sustento na área 
rural. Todavia, "dados estatísticos nos revelam que a tendência para a urbanização não foi realmente significativa no Japão, antes do século XX” (NOGUEIRA, 1984, p. 36-37).

Em segundo lugar, após a Restauração Meiji a expansão demográfica passou a ser vista como um fator importante para o desenvolvimento nacional. Com o advento da melhoria de organização médico-hospitalar, vacinação e assistência da população em geral, acelerou-se ainda mais o aumento populacional (NOGUEIRA, 1984, p. 36).

Assim, a opção de emigração tornou-se uma necessidade urgente. Na era Meiji (1868-1912), com o fim do isolamento do país, a emigração dos japoneses começou a tomar impulso pela iniciativa de empresas privadas, e aumentou paulatinamente. Comparando-se esses movimentos emigratórios com os de países europeus, os do Japão eram tardios, em relação ao período em que se deram, e menores em termos de seu número. A primeira empresa recrutadora de emigração foi fundada em 1891 no Japão. Contudo, os movimento emigratórios dessa época ainda estavam numa fase confusa. Muitas das empresas recrutadoras de emigração visavam apenas obter a comissão e tendiam a não oferecer as condições adequadas de vida e de trabalho para esses emigrantes. Alguns foram enviados sem o visto do país receptor e, assim, foram deportados, outros partiram para países com os quais o Japão não havia assinado acordo, portanto, de certa forma, foram iludidos em seus objetivos, passando, então, por dificuldades extremas (KONNO, 1984, p. 18).

O governo japonês tomou medidas legais para proteger os emigrantes e fiscalizar as empresas recrutadoras de emigração. Porém, essas medidas não objetivavam a promoção da emigração (KONNO, 1984, p. 19), porque o governo japonês, em princípio, mesmo não proibindo a saída dos japoneses, não era a favor da emigração; o Ministério dos Assuntos Internos não a priorizou, por receio de que os jovens com experiência de estada no exterior pudessem trazer filosofias políticas desfavoráveis ao país; e o Ministério da Guerra alegava 
que a emigração reduziria o número dos potenciais soldados que fossem necessários nos momentos críticos (KONNO, 1984, p. 26). Na esfera civil, havia muitos candidatos a emigrantes que desejavam trabalhar temporariamente como decasségui, além de inúmeras pessoas que consideravam a emigração uma solução de superpopulação. As empresas recrutadoras de emigração e de transporte marítimo, sabedoras dessas posições, procuraram os países receptores para poderem, sutilmente, ativar o maior número de emigrantes (KONNO, 1984, p. 27). Por todos esses entraves, o governo japonês somente iniciou a promoção da emigração ativamente nos anos 1920.

Durante quase 80 anos, após a Restauração Meiji até o final da Segunda Guerra Mundial, o número total de emigrantes japoneses chegou ao patamar de 1.013 .000 pessoas. Porém, subtraindo-se desse número os quase 270 mil emigrantes colonizadores do Manchu-kuo, sobram apenas 750 mil, número inferior ao da emigração que ocorreu na Noruega, por exemplo, nesse mesmo período (SBCJ, 1992, p. 37). O início tardio da emigração (após a Restauração Meiji, em 1868) e as restrições gradualmente impostas em vários países receptores aos emigrantes japoneses foram os principais fatores desse número inferior ao da Noruega. Mas, apesar disto, os imigrantes japoneses espalharam-se por numerosos países: Havaí (que era um reino independente na época), Estados Unidos, Canadá, Austrália, Brasil, Peru, Argentina, Bolívia, Paraguai, etc.

O primeiro país receptor dos imigrantes japoneses foi o Havaí, que recebeu 148 pessoas em 1868, no mesmo ano da Restauração Meiji. Além de ter muita demanda de mão de obra no canavial, a ilha serviu também como um ponto intermediário para a entrada nos EUA e para o Canadá. Para o Haiti haviam emigrado aproximadamente 165 mil japoneses, e, por volta de 1898, quando os EUA anexaram o reino como parte do seu território, os japoneses 
representavam quase $40 \%$ da população havaiana. ${ }^{20}$ Porém, após a anexação, os EUA, que não eram tolerantes à imigração oriental, mudaram o tratamento dado para os imigrantes japoneses (SBCJ, 1992, p. 34-35).

A imigração japonesa para os EUA, oficialmente, iniciou-se em 1880, e levou 400 mil japoneses até 1911. Porém, simultaneamente, com o aumento desse número, eles passaram a sofrer várias restrições baseadas no preconceito. Em 1906, na cidade de São Francisco, aconteeu a rejeição da entrada das crianças japonesas em escolas americanas. Em 1907, a imigração através do Havaí foi proibida. Em 1908, o governo japonês procurou a melhoria da situação, restringindo o número dos próprios emigrantes através do Gentleman's Agreement. ${ }^{21}$ Mesmo assim, as desconfianças dos americanos não foram resolvidas. Eles viam os japoneses como um perigo potencial na ocupação das vagas dos trabalhadores brancos, porque acreditava-se que se dispusessem a aceitar salários mais baixos. Como imigrantes, os japoneses enviavam a maior parte de sua renda para seu país natal, assim também não contribuindo sociedade norte-americana. Além disso, os costumes, como o de casamento arranjado mediante a troca de fotos, pareceram imorais sob o ponto de vista ocidental. Em 1913 e 1921, no Estado da Califórnia, foram tomadas medidas proibindo a posse de terra pelos estrangeiros. Antes da Segunda Guerra Mundial, as difíceis situações que cercavam a imigração japonesa nos EUA chegaram ao seu ponto culminante com a nova Lei de Imigração de 1924 (The Immigration Act of 1924). Essa lei fixou 2\% dos nacionais residentes de cada país no ano de 1890, como um limite de novos imigrantes. Como haviam entrado poucos japoneses até então, a nova lei veio prejudicar enormemente a imigração japonesa.

\footnotetext{
20 A porcentagem de japoneses no Havaí, no ano de 2000, representava 16,7\%.

${ }^{21}$ Gentleman's Agreement: acordo de cavalheiros realizado em 1908, entre o Ministro japonês de Relações Exteriores e o Embaixador americano no Japão. Com este acordo, o governo japonês decidiu restringir o número dos emigrantes para os EUA, exceto turistas, estudantes e famílias dos japoneses já residentes naquele país.
} 
Os países anglo-saxões, como EUA, Canadá e Austrália, que tradicionalmente recebiam imigrantes, foram os primeiros destinos dos emigrantes japoneses. Porém, gradualmente restrições foram impostas contra os japoneses emigrados para estes países. Além do caso dos EUA, em 1895, no Canadá foram tomadas providências restritivas à imigração japonesa. A partir de 1907, os japoneses passaram a ser alvo de campanhas antiorientais. Em seguida, foi assinado um acordo entre os dois países, segundo o qual o governo japonês se comprometia a limitar a saída dos japoneses para o Canadá (150 pessoas/ano). Na prática, esse acordo foi uma proibição da imigração japonesa (SBCJ, 1992, p. 34).

A maioria dos japoneses que se dirigiram à Austrália - país onde havia boas possibilidades de entrada (SBCJ, 1992, p. 34) -, lá se estabeleceram como colhedores de madrepérola, atraídos fortemente pelo elevado salário de 15 dólares por mês, e mais a possibilidade de lucros 5 mil ienes por ano. Porém, mais tarde ali se adotou um teste de línguas europeias, dificultando a entrada das pessoas de diversas nacionalidades.

Com as restrições da emigração para esses países anglo-saxões, somadas à necessidade de envio do povo para o exterior, pelos motivos já referidos no capítulo 3 , o Japão iniciou a procura por novos países receptores. Surgiram, então, os países da América Latina e, posteriormente, as colônias japonesas na região asiática. Os principais países latino-americanos que receberam os imigrantes japoneses foram: Brasil, Peru, México, Paraguai, Argentina, Chile, Bolívia, Colômbia e República Dominicana. Em termos de números, destacam-se as imigrações japonesas para o Brasil (250 mil) e para o Peru (80 mil).

\subsubsection{Imigração japonesa no Brasil}

Os fatores de atração da migração japonesa no Brasil, em parte, já foram tratados no 
capítulo 3: abolição de escravatura e necessidade de mão de obra para a lavoura cafeeira. Pelo fato de, no ano de 1940, "mais da metade do Brasil encontrava-se, ainda, praticamente despovoada e não explorada do ponto de vista agrícola" (NOGUEIRA, 1984, p. 47), o Brasil mostrou-se muito apto à imigração. $\mathrm{O}$ suprimento da mão de obra para a lavoura cafeeira era uma tarefa que necessitava urgentemente ser resolvida. Como os imigrantes espontâneos raramente se dirigiam para a lavoura, o governo realizou uma estratégia da imigração estatal, oferecendo-lhes subsídios e hospedagem, e colocando-os nas fazendas de café (NOGUEIRA, 1984, p. 48). Com a diminuição gradual da imigração europeia, deu-se início à imigração japonesa no Brasil.

Pode-se dividir a história da imigração japonesa para o Brasil em três grandes fases: $1^{\text {a }}$ de 1908 a $1924 ; 2^{\text {a }}$ de 1925 a $1941 ; 3^{\text {a }}$ de $1952^{\text {a }} 1973$.

No início da imigração, os principais fatores causais foram a carência de mão de obra nas fazendas brasileiras de café, as dificuldades econômicas e a pobreza no Japão; além desses, houve ainda as restrições contra a imigração japonesa em vários outros países. Diante deste cenário, as empresas japonesas recrutadoras de emigrantes partiram para a busca de novos países na América Latina que aceitassem a emigração japonesa.

Após a proibição da imigração para o Brasil pelo governo italiano, o governo brasileiro passou a se interessar pela imigração japonesa. O projeto de imigração japonesa para o Brasil obteve também o consentimento do governo japonês através do Cônsul Geral japonês de São Paulo. Assim, foi celebrado um contrato que visava "importar 3 mil imigrantes japoneses no período de 3 anos" entre a Empresa Imperial de Colonização (Kôkoku Shokumin Gôshi Gaisha) e o governo estadual de São Paulo. Esta primeira fase da imigração japonesa (1908-1924), na qual foram introduzidos aproximadamente 35.000 japoneses, é caracterizada pelos subsídios oferecidos pelo governo estadual paulista de 10 libras esterlinas aos imigrantes 
com mais de 10 anos de idade.

Como é de conhecimento de todos, os primeiros imigrantes japoneses somaram 781 pessoas levadas pelo navio Kasato-Maru. Porém, não se pode dizer que essa tentativa teve sucesso. De um lado, muitos dos imigrantes, que deveriam ser agricultores, eram de diversos ofícios, oriundos da área urbana. Por outro, a empresa recrutadora de emigração havia iludido os japoneses com a falsa propaganda sobre a facilidade de ganhar dinheiro no Brasil (SBCJ, 1992, p. 71).

Se tudo corresse como propagavam os agentes de emigração, se cada colono colhesse 4 a 5 sacos de café, três colheriam 15 sacos; a 500 réis ( 30 sens) por saco colhido, teriam 4 ienes e 50 sens; num mês de 30 dias receberiam a fabulosa soma de 135 ienes (...) Como na realidade era difícil colher até mesmo 1 a 2 sacos por três pessoas de uma família, tinham toda razão para explodir de descontentamento e revolta (SBCJ, 1992, p. 71).

O caso do Kasato-Maru acabou em conflitos e atritos, fugas e abandonos coletivos. Esses péssimos resultados da primeira leva de imigração japonesa causaram grande prejuízo à Companhia Imperial de Colonização, cujo processo de imigração para o Brasil somente foi retomado dois anos depois.

Mesmo com este fracasso, no docorrer de 1910 o número de imigrantes japoneses para o Brasil foi aumentando. Em 1921, os subsídios oferecidos pelo governo estadual paulista foram cancelados, sob a alegação de: baixo índice de permanência nas fazendas de café; maiores despesas para o governo estadual que para os imigrantes europeus; além de tudo, dificuldades resultantes da diferença de língua, usos e costumes (SBCJ, 1992, p. 140). Porém, esse cancelamento de subsídios não reduziu o número da imigração japonesa. $\mathrm{O}$ governo japonês, sofrendo o prejuízo causado pelo Grande Terremoto de Kantô, de 1923, passou a intensificar a política emigratória (NOGUEIRA, 1984, p. 113). Já que em 1924 a imigração japonesa nos EUA fora proibida, havia necessidade de procurar destinos para essa emigração na América Latina. 
A segunda fase da imigração japonesa no Brasil (1925-1941) caracterizou-se pela imigração promovida pelo governo japonês. O número total dos imigrantes que entraram nesse período é de 150.000 pessoas, entre estes, 103.000 que entraram no Brasil entre 1928 até 1934.

Vale lembrar que, nos anos 1920, a economia japonesa passava por várias crises, até que eclodisse a mais séria delas, em 1930. Após um curto período de prosperidade durante a Primeira Guerra Mundial, o Japão enfrentou a Revolta do Arroz (1918), uma manifestação e quebra-quebra contra o alto preço do arroz, a quebra na Bolsa (1920) e o Grande Terremoto de Kantô (1923). Em 1927, com subsídio do governo japonês, foi fundada a Sociedade Colonizadora do Brasil (Bratac), uma empresa que oferecia apoio para a colonização. Segundo a Tabela 2, abaixo, durante quatro anos a partir de 1927, o número anual de entrada de imigrantes japoneses chegou ao patamar de 10 mil pessoas. Esse nível foi superado entre 1932 e 1934, chegando a 20 mil pessoas por ano em 1933 e 1934. Ressalta-se que, a partir de 1930, o Japão estava em crise na área rural e enfrentando uma séria recessão na área urbana, causada pelo Pânico de Showa. A partir de 1932, o governo japonês começou a oferecer, além da passagem, a soma de 50 ienes por pessoa para emigrantes com mais de 12 anos de idade (SBCJ, 1992, p. 142). O período entre 1927 e 1934 foi uma fase de grande expansão da imigração japonesa. Porem, segundo as empresas de emigração, em 1935 o mesmo número foi reduzido para quase 6 mil pessoas, e, a partir de 1938, esse número ficou reduzido até 2 mil pessoas.

Este fato se deveu à nova Constituição Federal, ocorrida no ano anterior. Sob a presidência de Getúlio Vargas, que iniciou seu mandato em 1930, o governo brasileiro passou a ser rigoroso com os estrangeiros. Em 1934, foi promulgada uma nova Constituição Federal inclusive um dispositivo que fixou, como limite máximo dos novos imigrantes, a cota de $2 \%$ do número de nacionais de cada país entrados no Brasil nos últimos cinquenta anos (SBCJ, 
1992, p. 167). Depois de passar por uma fase de grande expansão, a imigração japonesa no Brasil entrou num período de maiores dificuldades.

Após 1934, os números de entrada de japoneses foram sendo reduzidos drasticamente. Além disso, várias medidas restritivas contra a imigração estrangeira foram sendo tomadas. Em 1937, os órgãos da imprensa estrangeira e, em 1939, o ensino de língua estrangeira foram proibidos. Em dezembro de 1941, com o ataque contra Pearl Harbour, o Japão iniciou a guerra contra os EUA. O Brasil, foçado a tomar uma atitude definitiva, rompeu relações com os países do Eixo no início de 1942 e assinou um acordo político-militar, de caráter secreto, com os EUA (FAUSTO, 2007, p. 381-382). Assim, a entrada de japoneses antes da guerra foi definitivamente interditada, deixando os japoneses residentes no Brasil isolados do seu país natal e dos seus órgãos representativos (embaixada, consulado, etc.).

\begin{tabular}{|c|c|c|c|}
\hline \multirow[t]{2}{*}{ Ano } & Segundo & Segundo & Segundo \\
\hline & $\begin{array}{l}\text { as empresas de } \\
\text { emigração }\end{array}$ & $\begin{array}{l}\text { história da } \\
\text { expansão da } \\
\text { emigração } \\
\text { japonesa no Brasil }\end{array}$ & $\begin{array}{l}\text { o Departamento de } \\
\text { Imigração, } \\
\text { Ministério } \\
\text { Trabalho, } \\
\text { Comércio } \\
\text { Indústria do Brasil }\end{array}$ \\
\hline 1908 & 797 & $\begin{array}{r}18.800, \text { de } \\
1908 \text { a } 1917 \text { (antes }\end{array}$ & 830 \\
\hline
\end{tabular}




\begin{tabular}{|c|c|c|c|}
\hline & & $\begin{array}{c}\text { da fundação de } \\
\left.\text { Kaikôo }^{22}\right)\end{array}$ & \\
\hline 1909 & 0 & 0 & 31 \\
\hline 1910 & 906 & 0 & 947 \\
\hline 1911 & 0 & 0 & 28 \\
\hline 1912 & 2.844 & 0 & 2.809 \\
\hline 1913 & 6.948 & 0 & 7.122 \\
\hline 1914 & 3.497 & 0 & 3.675 \\
\hline 1915 & 0 & 0 & 65 \\
\hline 1916 & 13 & 0 & 165 \\
\hline 1917 & 4.038 & 18.800 & 3.899 \\
\hline 1918 & 5.903 & 5.903 & 5.522 \\
\hline 1919 & 2.679 & 2.679 & 3.022 \\
\hline 1920 & 982 & 982 & 1.013 \\
\hline 1921 & 923 & 923 & 840 \\
\hline 1922 & 528 & 965 & 1.225 \\
\hline 1923 & 516 & 891 & 895 \\
\hline 1924 & 4.985 & 3.705 & 2.673 \\
\hline 1925 & 4.912 & 4.638 & 6.330 \\
\hline 1926 & 7.639 & 8.192 & 8.470 \\
\hline 1927 & 10.050 & 9.152 & 9.034 \\
\hline
\end{tabular}

${ }^{22}$ Kaikô - kaigai kôkyô kabushiki gaisha: empresa recrutadora de imigrantes, criada em 1919 no Brasil, pela iniciativa do governo japonês, que sentia necessidade de uma empresa que favoreceresse a estratégia nacional. As várias empresas privadas já existentes foram integradas à Kaikô. 


\begin{tabular}{|c|c|c|c|}
\hline 1928 & 10.812 & 11.231 & 11.162 \\
\hline 1929 & 11.515 & 14.897 & 16.648 \\
\hline 1930 & 12.600 & 13.091 & 14.076 \\
\hline 1931 & 5.332 & 5.462 & 5.632 \\
\hline 1932 & 15.887 & 15.021 & 11.678 \\
\hline 1933 & 21.000 & 23.152 & 24.484 \\
\hline 1934 & 21.702 & 22.832 & 21.230 \\
\hline 1935 & 6.400 & 5.648 & 9.611 \\
\hline 1936 & 5.373 & 5.298 & 8.306 \\
\hline 1937 & 4.642 & 4.642 & 4.557 \\
\hline 1938 & 2.552 & 2.555 & 2.524 \\
\hline 1939 & 1.294 & 1.303 & 1.414 \\
\hline 1940 & 1.556 & 1.556 & 1.471 \\
\hline 1941 & 1.350 & 0 & 1.883 \\
\hline Subtotal & 179.321 & 183.518 & 188.309 \\
\hline \multicolumn{4}{|c|}{ Imigrantes para a colônia de Iguape, até 1920: } \\
\hline & 1.744 & 0 & 0 \\
\hline Total & 181.065 & 183.518 & 188.309 \\
\hline
\end{tabular}

Tabela 2 - A entrada de Imigrantes Japoneses no Brasil - de 1908 a 1941 (SBCJ, 1992, p. 138).

\subsubsection{Mudança da imigração japonesa no Brasil}

Até aqui foi visto o processo de início da imigração japonesa no Brasil. Agora, serão 
vistas as mudanças ocorridas entre os imigrantes japoneses. Exceto casos de alguns projetos de emigração realizados pelo governo e entidades privadas japoneses (como o da colônia Aliança ${ }^{23}$ ), a maioria dos japoneses, logo depois da sua chegada ao Brasil, foram para fazendas de café como colonos contratados. Gradualmente, eles começaram a perceber que a vida na fazenda não traria a economia desejada, e saíram em busca de outras maneiras para realizar sua independência econômica.

$\mathrm{O}$ período de chegada de japoneses na primeira metade do século $\mathrm{XX}$ ao Brasil coincide com o da última fase da "onda verde", o deslocamento de cafezais à procura de terras virgens para o oeste da capital paulista e, mais tarde, para a região Norte do Paraná. Após obterem uma certa quantia de dinheiro no trabalho nas fazendas, os imigrantes deslocaram-se para o interior do Estado de São Paulo, comprando terrenos inexplorados, derrubando matas e desbravando as terras (SBCJ, 1992, p. 81), processo ocorrido principalmente na segunda metade da década de 1910 até a de 1920, formando-se assim vários núcleos coloniais no interior de São Paulo.

[...] o decênio de 1920 representou uma fase de frenética e desvairada movimentação dos imigrantes nipônicos no sentido de desbravar novas fronteiras. Por outro lado, representou um tempo em que eles foam despertando para a necessidade de uma longa residência (SBCJ, 1992, p. 113).

No decorrer dos anos, o primeiro desejo de voltar ao Japão em poucos anos com os recursos obtidos estava se desfazendo. Os imigrantes japoneses perceberam que era impossível obter a quantia desejada em princípio em poucos anos, por isso foram prolongando sua estada. Além do desbravamento de terras virgens, havia outras maneiras encontradas para alcançar a independência econômica, como, por exemplo, o trabalho como lavrador autônomo (SBCJ,

\footnotetext{
${ }^{23}$ Colônia Aliança: criada pela iniciativa privada. Diferentemente da imigração japonesa em geral (sua imensa maioria subsidiada pelo governo japonês), imigrantes destinados a esta colônia visavam, desde o início, radicalização no Brasil.
} 
1992, p. 77). Em certas fazendas, após os colonos cumprirem seu prazo de contrato, seus proprietários costumavam, gratuitamente ou mediante um pagamento simbólico, ceder-lhes parte das terras ainda inexploradas para que as cultivassem. Os japoneses cultivavam produtos como arroz, feijão, milho, etc. e, com isso, chegaram ocasionalmente a obter um lucro inesperado (SBCJ, 1992, p. 79). Havia, ainda, uma forma de parceria agrícola. Nesse sistema, aqueles que não possuíam uma quantia suficiente para comprar o terreno virgem, podiam cultivar terras arrendadas, com as despesas pagas pelo proprietário das terras até a hora da colheita, cujo resultado da venda era dividido entre o proprietário e o lavrador arrendatário (SBCJ, 1992, p. 80). É óbvio que os japoneses, nessa época, buscaram a melhor maneira de viver como agricultores.

Até hoje, no interior do Estado, há várias cidades com alta porcentagem de população nipônica. Posteriormente, na passagem dos anos 1940 para 1950, esse deslocamento dirigiu-se para o Estado de Paraná, onde existem cidades cujo nome é de origem japonesa, como, por

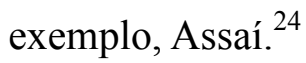

Um recenseamento da comunidade nikkei realizado em 1958, portanto, após a guerra, indica a alta porcentagem da agricultura entre as profissões de nikkei: 57\% (SBCJ, 1992, p. 435). Numa outra pesquisa, realizada pela Beneficiência Nipo-Brasileira de São Paulo, em 1978, abrangendo 75.151 japoneses (incluindo-se os de dupla nacionalidade e naturalizados) residentes nos Estados de São Paulo, Paraná, Mato Grosso e Minas Gerais, o mesmo índice mostrou uma taxa de 19,3\% (SBCJ, 1992, p. 435). Mas esses números não podem ser simplesmente comparados, há que se considerar diferentes circunstâncias sob as quais as pesquisas foram realizadas, pois, na segunda pesquisa, não estão incluídos os nikkei

\footnotetext{
24 Assaí: nome da cidade paranaense, cuja origem vem da língua japonesa. O termo Asahi significa o sol nascente.
} 
que possuem apenas a nacionalidade brasileira.

Enfim, após passar o primeiro momento quando os japoneses se dedicaram ao campo, a tendência de mudança de profissão foi ficando cada vez mais evidente.

Para considerar a prorrogação da estada dos japoneses, é importante o impacto que a Segunda Guerra Mundial causou. Com o início da guerra, a relação diplomática entre o Brasil e o Japão foi interrompida, e os bens de japoneses residentes no Brasil foram congelados. Em termos gerais, até essa altura os imigrantes japoneses mantinham aceso o desejo de regresso para a terra natal. Porém, o rompimento da comunicação e do transporte, durante os quatro anos da guerra, e a subsequente fase de conflitos internos na comunidade japonesa, os forçaram a tomar consciência de que o regresso não era mais uma opção viável.

A derrota do Japão na Segunda Guerra Mundial trouxe consequências desastrosas à população daquele país, demonstrando claras evidências de que o momento não era oportuno para os imigrantes japoneses, que lutavam no Brasil, regressarem ao Japão. E, além do mais, muitos imigrantes e, principalmente, seus filhos já se tinham acostumado à vida no Brasil. Como diz Nogueira, “os velhos imigrantes 'redescobrem' sua condição de serem pais e avós de brasileiros. Chegava a hora de encarar a si mesmo com elementos cuja alma e corpo se ligavam diretamente à nova pátria" (1984, p. 115). A partir dessa época, a maioria dos japoneses decidiu permanecer definitivamente no Brasil e, para alcançar uma ascensão social mais segura e rápida, eles resolveram dar melhor escolaridade aos filhos, o que provocou um novo deslocamento. A comunidade nikkei agora saía das roças em direção às cidades.

\subsection{Migração japonesa pós-guerra e sua cessação}

No Japão, no período logo após a derrota da Segunda Guerra Mundial até o Tratado 
de São Francisco (em 1951), a questão da emigração não foi tratada concretamente. O Japão, no seu estado devastado logo depois da guerra, não tinha condições de oferecer meios de vida para a população e os quase 7 milhões de retornados das antigas áreas ocupadas (HITOMI et al., 1996, p. 269). Houve algumas tentativas ocasionais para considerar a possibilidade de emigração, porém, sob a ocupação das tropas norte-americanas, não foram concretizadas (KONNO, 1984, p. 183; SBCJ, 1992, p. 381-382).

Assim, iniciou-se a terceira fase da imigração japonesa para o Brasil (1952-1973), com a vinda de cerca de 53 mil novos imigrantes. O fato de imigrantes japoneses dificilmente se misturarem com a população local e de terem causado um conflito interno na própria comunidade japonesa dificultou a aceitação da nova imigração japonesa pelas autoridades brasileiras. Mesmo assim, o reinício da imigração japonesa no período pós-guerra deu-se em 1953, após ter vigorado o Tratado de São Francisco, um tratado de paz, entre o Japão e os 48 ex-países inimigos (SBCJ, 1992, p. 381-382).

São características da imigração japonesa pós-guerra: não necessidade de passagem para fazendas de café; alta presença de jovens solteiros; muitos dos imigrantes já eram proprietários de terrenos antes da sua chegada; a presença de imigrantes técnicos junto a agricultores. Os dois terços dos imigrantes pós-guerra chegaram ao Brasil nos primeiros oito anos (1952-1959), em sua maioria agricultores.

Diferentemente da imigração japonesa estatal antes da guerra, uma estratégia nacional, movimentos imigratórios de japoneses no período pós-guerra deram-se mais pela iniciativa privada, como o caso dos "imigrantes Tsuji" e "Matsubara". Tsuji e Matsubara, japoneses residentes no Brasil e amigos de Getúlio Vargas, tomaram iniciativas próprias, aproveitando essa amizade como uma forma de "diplomacia particular", cujo objetivo era enviar japoneses para a Amazônia, o Centro-Oeste e o Nordeste (SBCJ, 1992, p. 382). Além 
desses casos pioneiros, em resposta a uma ideia de um por um funcionário técnico do Ministério de Obras Públicas do governo japonês, houve também a imigração sericultora para o Estado de São Paulo, promovida pela Sociedade Paulista de Sericultura e seus associados japoneses, pelos chamados "jovens imigrantes da Cotia” (Cotia Seinen Imin), da Cooperativa Agrícola de Cotia, e pelos Grupos de Jovens para o Desenvolvimento Industrial (Sangyo Kaihatsu Seinentai) (SBCJ, 1992, p. 383-388). No nível governamental, um acordo sobre a imigração chegou a ser firmado em 1960 e validado em 1963, porém, nessa época, junto com crescimento econômico do Japão, a emigração para o Brasil começou a diminuir. Seu auge foi atingido quando, em 1959, emigraram 7.041 pessoas, caindo para $6.832 \mathrm{em} \mathrm{1960;5.146 \textrm {em }}$ 1961; 1.830 em 1962; 1.230 em 1963; e 751 em 1964 (SBCJ, 1992, p. 391-393). Como fatores dessa diminuição, do lado do Japão, além da possiblidade de emigração para países como Canadá e Austrália, houve crescimento econômico, tornando possível absorver o excedente populacional nas indústrias; do lado brasileiro, a crescente população da região Nordeste começou a migrar para a região Oeste, dispensando assim mão de obra estrangeira (SBCJ, 1992, p. 393).

\begin{tabular}{|c|c|c|c|c|c|}
\hline $\begin{array}{ll}\text { Ano/Cat } \\
\text { egoria }\end{array}$ & $\begin{array}{ll}\text { Lav } & \\
\text { oura }\end{array}$ & $\begin{array}{ll} & \text { Téc } \\
\text { nicas } & \end{array}$ & \begin{tabular}{|r|} 
Com \\
ércio e outros
\end{tabular} & $\begin{array}{l}\text { Vi } \\
\text { ndos por } \\
\text { chamadas } \\
\text { nominais }\end{array}$ & tal \\
\hline $\begin{array}{l}1952-19 \\
59\end{array}$ & $\begin{array}{r}16.1 \\
91\end{array}$ & 251 & 44 & $\begin{array}{r}14 . \\
124\end{array}$ & $\begin{array}{r}30 \\
.610\end{array}$ \\
\hline 1960-19 & 8.19 & 1.36 & 539 & 8.4 & 18 \\
\hline
\end{tabular}




\begin{tabular}{|c|c|c|c|c|c|}
\hline 69 & 1 & 5 & & 06 & .619 \\
\hline $1970-19$ & 1.56 & 3.37 & 41 & 62 & 3. \\
\hline 79 & 4 & 7 & & 8 & 610 \\
\hline 1980 & 67 & 58 & 7 & 56 & 18 \\
\hline 1981 & 80 & 32 & 4 & 45 & 16 \\
\hline 1982 & 13 & 16 & 0 & 32 & 61 \\
\hline 1983 & 58 & 5 & 0 & 21 & 84 \\
\hline 1984 & 44 & 0 & 1 & 15 & 60 \\
\hline 1985 & 19 & 0 & 4 & 22 & 45 \\
\hline 1986 & 31 & 0 & 0 & 20 & 51 \\
\hline 1987 & 23 & 0 & 0 & 17 & 40 \\
\hline 1988 & 25 & 1 & 0 & 0 & 26 \\
\hline Total & 26.4 & 3.10 & 640 & 23. & 53 \\
\hline & 24 & 5 & & 386 & .555 \\
\hline
\end{tabular}

Tabela 3 - Número de imigrantes do pós-guerra, segundo sua categoria - 1952-1973 (SBCJ, 1992, p. 424). 


\section{CAPÍTULO 5 - FENÔMENO DECASSÉGUI}

\subsection{Revisão histórica da migração - Definição do fenômeno decasségui}

A partir de meados dos anos 1980, os brasileiros nikkei, descendentes dos imigrantes japoneses, começaram a emigrar para o país de seus ancestrais. Esse movimento migratório em sentido inverso é chamado de movimento decasségui.

Primeiramente, o que é fenômeno decasségui? No Novo Dicionário de Aurélio, o termo decasségui é assim definido: "Diz-se de, ou estrangeiro, freqüentemente descendente de japoneses, que vai trabalhar no Japão". Porém, de fato, atualmente o fenômeno decasségui significa a corrente de trabalhadores estrangeiros, na sua maioria descendentes de imigrantes japoneses da América Latina, partindo para o Japão, a fim de ocupar, principalmente, as vagas de trabalhos monofuncionais naquele país.

Os trabalhadores decasségui dos países da América Latina, especificamente os do Brasil, com o objetivo de exercer trabalhos monofuncionais, já começavam a ser vistos no Japão na segunda metade dos anos 1980, mas foi somente após a reforma da Lei de Controle de Imigração e Reconhecimento de Refugiados (doravante simplesmente denominada como Lei de Controle de Imigração) em 1989 (que entrou em vigor no mês de junho de 1990) que este contingente começou a aumentar de maneira progressiva, processo ativo até os dias atuais.

Nas abordagens sobre movimentos migratórios, a explicação mais comumente empregada é a de atração-repulsão (push-pull). Ou seja, nos países de origem existem os fatores de repulsão, e nos países de destino, os de atração. Nesta seção, busca-se esclarecer a sua origem histórica deste fenômeno chamado decasségui.

No Japão, antes da Segunda Guerra Mundial, constatava-se a entrada de migrantes em 
grande massa que, na sua quase totalidade, vinham da Coreia, à época colônia japonesa. Com o fim da guerra e sob o clima da derrota, deu-se o regresso de japoneses residentes das antigas colônias japonesas (da China, principalmente da região nordeste, ou da Coreia), período em que o país passou por uma fase de oferta excessiva mão de obra e de dificuldades econômicas. Após a rápida reconstrução do país, nos anos 1970, os "prenúncios das disparidades entre a oferta e a demanda no mercado de trabalho já haviam sido sentidos (...) estas foram contornadas, à época, pela recessão causada pelos choques do petróleo" (CORRÊA COSTA, 2007, p. 38). Na época, os imigrantes coreanos, chineses, filipinos e outros asiáticos já estavam trabalhando no Japão, "atraídos pelo desenvolvimento econômico em processo neste país" (KAWAMURA, 1998, p. 42).

O crescimento econômico japonês atingiu se ápice na época da "Economia de Bolha", num período de prosperidade econômica que durou de 1986 até 1991, resultando em especulações de ações, de imóveis e de abundância de ofertas de emprego. A expansão econômica, combinada com a tendência da elevação do nível de escolaridade e a capacitação profissional por parte dos trabalhadores japoneses, que os levaram a evitar os trabalhos monofuncionais, "provocou uma ativa movimentação de trabalhadores asiáticos - e, no final da década, também de latino-americanos - em sua direção, atendendo a busca desenfreada de mão de obra carente no país, por médias e pequenas empresas do setor eletrônico em expansão" (KAWAMURA, 2003a, p. 42-44).

Diante da escassez total de mão de obra, as empresas foram pressionadas, e chegaram a contratar os trabalhadores estrangeiros, cujo corpo principal era de origem asiática, advindos de países como Bangladesh, Paquistão, Irã ou Malásia, na maioria das vezes, na condição de ilegais (KAWAMURA, 2003a, p. 42-44). Segundo Kitagawa (1992), foi na segunda metade de 1987 que a presença do nikkei brasileiro começou a ser vista no Japão, embora ainda de forma 
ilegal (exceto os isseis, imigrantes japoneses que retornavam para a terra natal). Nessa época, os nisseis e sanseis entraram no país com visto de curta permanência, alterando posteriormente seu status para visita a parentes (NINOMIYA, 2002, p. 374). A autoridade japonesa, preocupada com o aumento dos migrantes ilegais, decidiu alterar a Lei de Controle de Imigração, em 1990, permitindo a entrada e a permanência de filhos e netos de japoneses residentes no exterior.

A carência de mão de obra dava-se, com mais destaque, em determinadas áreas industriais, como de construção e de produção (MORI, 2002, p. 362). Na área industrial de produção, principalmente nas produções automobilísticas e eletrônicas, após o Acrodo de Plaza assinado em 1985, a subida do iene exigiu alta competitividade desses produtos no exterior, o que obrigou as empresas a reduzirem seu custo de produção. $\mathrm{Na}$ estrutura dual japonesa de produção, as pequenas e médias empresas assumem serviços encomendados pelas grandes, com remuneração não muito alta. Nesse contexto, a falta de mão de obra intensificou-se ainda mais nas pequenas e médias empresas, criando grande procura de trabalhadores estrangeiros (MORI, 2002, p. 362). Nas áreas de serviço também houve abertura de vagas, como: produção de alimentos (principalmente para marmitas); atendentes nos hotéis; serviços de manutenção/administração e de carregadores de tacos no campo de golfe (MORI, 2002, p. 362). Nesses serviços não se exigia alta capacidade nem habilidade no idioma japonês (MORI, 2002, p. 362). Nessa época, os valores dos salários dos trabalhadores decasségui foram, em média, de trezentos mil a quatrocentos mil ienes (inclusive remuneração de horas extras) (NINOMIYA, 2002, p. 377).

\subsubsection{Revisão histórica da migração-Origem do movimento decasségui}


Além dos fatores de atração conferidos no item anterior, foi visto no capítulo 2 que existem os fatores de repulsão, os fatores que incentivam a emigração, por parte do Brasil.

O Brasil, que era um país essencialmente de agricultura, a partir dos anos 1930 iniciou seu processo de industrialização. Durante as décadas do governo militar (1964-1984), a industrialização foi ainda mais acelerada (DEL PIORE, 1997, p. 106-109).

De um lado, nos anos 1970 houve o chamado milagre econômico, marcado pelo "estabelecimento de empresas multinacionais" e pelo "investimento maciço de capital estrangeiro". Porém, esse crescimento acarretou um altíssimo endividamento externo e uma violenta concentração de renda (DEL PIORE, 1997, p. 106-109). Quando o Choque do Petróleo atingiu o Brasil, "emergiu um país altamente endividado (externa e internamente), com inflação crescente, um parque industrial modernizado (na região Sudeste) e um abismo social cada vez maior separando ricos e pobres, Norte e Sul do país" (DEL PIORE, 1997, p. 106-109).

Por outro, os anos 1980 do Brasil são conhecidos como a "década perdida" marcada, principalmente pela hiperinflação e pela crise de dívidas externas. A despeito do processo de democratização na esfera política, na esfera econômica as condições de vida da população brasileira deterioraram-se. Nesse contexto, a situação da classe média brasileira tornou-se difícil. Segundo Schwartz (1992), a classe média não apenas empobreceu como foi destruída, resultando até no "cancelamento de expectativas de mobilidade social" (SCHWARTZ, 1992, p. 213). Como fatores causais do movimento decasségui no lado brasileiro, pode-se citar: alta taxa de desemprego; e a inflação, que chegou aos três dígitos (Mori, 2002, p. 361). Visando conter a inflação, uma série de planos econômicos de choque foram adotados, chegando ao ponto máximo com o Plano Collor, em 1990, que consistia basicamente na retirada de moeda de circulação mediante um confisco dos numerários depositados em estabelecimentos 
bancários. O ano de 1990 também foi quando a Lei de Controle de Imigração, no Japão, entrou em vigor. Essa coincidência é interessante, pois, como diz Corrêa Costa, do lado brasileiro, o Plano Collor foi o marco histórico do movimento decasségui, dando grande ímpeto aos fatores de repulsão (CORRÊA COSTA, 2007, p. 42). Chega-se assim à conclusão de que a época da prosperidade econômica japonesa aconteceu simultaneamento à crise geral do Brasil. Assim, a maioria dos descendentes de japoneses, nikkei, que se situavam na classe média, começaram a buscar uma maneira de compensação da perda econômica. Kawamura (2003a) comenta esse processo:

O aceno do Japão, país afluente e potência econômico-tecnológica, criou sonhos na maioria dos candidatos a trabalhar, cujo imaginário passou a povoar-se de dinheiro, aparelhos e equipamentos tecnológicos sofisticados, qualidade de vida de Primeiro Mundo - onde poderiam permanecer por pouco tempo e voltar ao Brasil bem-sucedidos. O caminho mostrou-se bastante árduo, demorado, e até doloroso para muitos (KAWAMURA, 2003a, p. 44).

Nesse contexto, em termos de microeconomia, a emigração dos brasileiros para o Japão surgiu na análise da relação custo $x$ benefício. De um lado, o alto iene em 1985 criou uma grande diferença salarial entre o Brasil e o Japão, causando boa impressão aos trabalhadores decasségui. Por outro, as diminuições das restrições para empresas aéreas causaram uma concorrência pelos preços da passagem aérea, baixando o custo da viagem entre os dois países (MORI, 2002, p. 361).

O outro fator importante, a reforma da Lei de Controle de Imigração, se deu em 1989 (e entrou em vigor em 1990). O Japão, oficialmente, nunca aceitou os trabalhadores estrangeiros para atividades monofuncionais. Apesar de serem descendentes de japoneses, antes dessa reforma aos nikkei ainda não era permitida a entrada dos que não possuíssem nacionalidade japonesa para exercer os trabalhos monofuncionais. Porém, dada a nova 
situação no final dos anos 1980 , ou seja, com o aumento do new comer, ${ }^{25}$ que também objetivavam trabalhar, o governo japonês se decidiu pela reforma da citada Lei que, agora, continuava proibindo a entrada de trabalhadores monofuncionais, mas, no entanto, criou alguns status para permanência no país, excepcionalmente sem restrição para alguns tipos de atividade, inclusive trabalhos monofuncionais, como "Residentes em caráter permanente especial" (tokubetsu eijûsha), "Residentes por longo período" (teijûsha), "Cônjuges e filhos de japoneses" (nihonjin no haigûsha nado), "Cônjuges e filhos de residentes em caráter permanente" (eijûsha no haigûsha nado). O status "Residentes em caráter permanente especial" visa principalmente à terceira geração dos coreanos migrados antes da guerra, porém, os de "Residentes por longo período" e "Cônjuges e filhos de japoneses" permitiram, na prática, a entrada e a permanência para os trabalhos monofuncionais (nikutai rôdô) dos descendentes de imigrantes japoneses, que se utilizavam da desculpa de visita aos parentes no Japão. O status "Residentes por longo período" (teijûsha) garantia permanência de três anos para os comprovadamente descendentes de japoneses (Ninomiya, 2002, p. 361).

Após a reforma da Lei, entre os status acima, a entrada de "Residentes por longo período" (teijûsha) e de "Cônjuges e filhos de japoneses" (nihonjin no haigûsha nado), cujo grande contingente, composto praticamente pelos descendentes de japoneses da América Latina, cresceu rapidamente. Ou seja, graças à reforma da Lei, iniciou-se o chamado movimento decasségui que, até hoje, levou mais de 310.000 trabalhadores brasileiros para o Japão. No final de 2004, o número de decasségui chegou a ser de 280.000. Se se acrescentar aqueles que têm dupla nacionalidade, o número total é estimado em mais de 300.000 pessoas.

\footnotetext{
25 New comer: denominação dada aos trabalhadores estrangeiros que começaram a aparecer mais recentemente no Japão, a maioria nos anos 1980, de origens diversas, para a busca de trabalho. Frequentemente essa denominação é utilizada em contraste com old comer, os coreanos e chineses, que migraram para o país do início até meados do século XX com o mesmo objetivo.
} 
Os retornados para o Brasil são estimados em mais de 150.000. Ou seja, durante 15 anos, desde 1990 até 2004, mais de 1,5 milhões brasileiros (descendentes e não descendentes) foram trabalhar no Japão (NINOMIYA, 2002, p. 374).

Portanto, mesmo não sendo reconhecido oficialmente pelo governo japonês, o decasségui acabou se tornando, "oficiosamente", o primeiro caso típico de entrada de trabalhadores estrangeiros de uma quantidade considerável no moderno Japão. Tendo em vista que este país ainda necessita de maior número de mão de obra por causa do envelhecimento de população, pode-se dizer que o início desse movimento foi um teste para a aceitação e a integração dos trabalhadores estrangeiros no país. E assim, conforme comenta Kajita (2005a), as pesquisas pertinentes ao decasségui, por se tratar de um fenômeno inexplorado, passam a ter um valor estratégico para pesquisadores japoneses, resultando em múltiplas pesquisas com temas como sociedade local, trabalho, educação, previdência social e outros.

Na segunda metade dos anos 1980, o aumento de descendentes de japoneses da América Latina estava evidente no Japão. O governo japonês sentiu necessidade de uma solução drástica para a questão desses trabalhadores. Para legalizar tal situação, em 1989 foi decidida a reforma da Lei de Controle de Imigração (que entrou em vigor no mês de junho de 1990). Ou seja, essa reforma aconteceu para aprovar um "fato consumado" (NINOMIYA, 2002, p. 374). O governo japonês alegou que essa reforma legal não havia sido motivada pela presença de trabalhadores nikkei. Porém, como um resultado final, as permanências das pessoas nikkei para trabalhos monofuncionais foram permitidas (NINOMIYA, 2002, p. 374).

\subsection{Mudança do fenômeno decasségui}

Desde o início do fenômeno decasségui já se passaram quase 20 anos, e, no decorrer 
desse tempo, houve várias mudanças entre os brasileiros residentes no Japão. Kajita (1998) comenta as características do fenômeno decasségui:

Os isseis, nisseis e sanseis, que possuem características diferentes, vinham chegando ao Japão seguidamente num período relativamente curto e, com isso, mudaram os atores principais, as naturezas e os objetivos do decasségui. Simultaneamente, ao passar de uma geração para a outra mais nova, as peculiaridades de "nikkei" tornam-se menos evidentes, e a relação com a sociedade receptora também tem se alterado gradualmente (KAJITA, 1998).

Ou seja, os trabalhadores decasségui são indivíduos diferentes em termos de gerações, naturezas e objetivos. Conforme a observação de Higuchi (2006), pode-se dividir o movimento decasségui em cinco diferentes fases conforme as principais características. Cada uma dessas fases reflete as mudanças estruturais do Brasil e do Japão, assim como a formação e a transformação do sistema migratório que influenciam o fenômeno decasségui (HIGUCHI, 2006).

Na primeira fase (1980-1984), o movimento migratório foi um regresso invisível pelos isseis, sinalizado como fracasso e falta de sucesso no Brasil (HIGUCHI, 2006). Os isseis, aqueles que desde o Kasato-Maru (1908) haviam emigrado para o Brasil, iniciaram o caminho de volta ao Japão, estabelecendo a rede de $\operatorname{contato}^{26}$ com o Japão. Nessa época, a natureza do decasségui era considerada algo humilhante, pois os isseis iam para o Japão, por exemplo, a fim de quitar dívidas contraídas em razão do fracasso de sua imigração para o Brasil, muitas vezes nem visitando os familiares no Japão.

Na segunda fase (1985-1989), iniciou-se a formação da rede de recrutamento. Nesse período, existiam condições estruturais em ambos os países que influenciaram o recrutamento de mão de obra. De um lado, no Brasil, no decorrer dos anos 1980, a taxa de inflação superou

\footnotetext{
${ }^{26}$ Rede de contato: uma rede que liga o país de origem e o país de destino, promovendo migração. Enquanto os fatores estruturais (como circunstâncias do mercado e do Estado) causaram o processo imigratório, a rede é formada pela correnteza dos imigrantes nesse processo interagindo com os fatores estruturais. Uma vez formada, a rede passa a ter uma função autossuficiente. Ou seja, mesmo que os fatores estruturais fiquem alterados, a rede continuaria promovendo o movimento imigratório. Portanto, muitas vezes, a formação da rede de contato traria um resultado contrário à previsão do Estado (Kajita, 2005a).
} 
os $100 \%$, atingindo $682 \%$ em 1988 , e $1.769 \%$ em 1989 . Este foi um dos fatores que provocaram a emigração dos brasileiros em geral, assim como a dos descendentes de japoneses. De fato, entre 1986 e 1990, o governo brasileiro confirmou 1,4 milhões de brasileiros emigrados para o exterior (HIGUCHI, 2006). Por outro, as crises econômicas do Brasil coincidem com o boom econômico do Japão. Após o Acordo de Plaza, em 1985, a taxa de câmbio rapidamente fortaleceu o iene japonês. Em 1990, o valor do iene, comparado com o do dólar americano, chegou ao ponto de ser duas vezes mais alto que cinco anos atrás. Isso tornou o trabalho no Japão extremamente atraente, tanto para os nikkei como para os trabalhadores asiáticos (HIGUCHI, 2006). Simultaneamente, as pequenas e médias empresas japonesas e fábricas estavam sofrendo com a escassez extrema de mão de obra. Em geral, esses são os fatores de repulsão e de atração que influenciaram a migração brasileira para o Japão (HIGUCHI, 2006).

É verdade que a reforma da Lei de Controle de Imigração Japonesa, em 1990, provocou o fenômeno decasségui. Porém, as redes sociais que facilitaram a decisão individual de cada imigrante já existiam no final dos anos 1980. A mudança maciça dos brasileiros para o Japão não teria ocorrido sem essas redes: agências de recrutamentos e recrutadores que procuravam e enviavam os trabalhadores brasileiros para o Japão. Foram eles que garantiram para nikkei os trabalhos no Japão, como, por exemplo, na fábrica da Toyota, na cidade de Toyota, ou na fábrica da Sony, na cidade de Toyohashi. A maioria dos brasileiros não teria emigrado sem essa garantia. No caso do decasségui, os recrutadores de mão de obra serviam como uma "conexão" das condições do nível macro (nível estrutural) e as oportunidades de trabalho do nível micro (nível individual) (HIGUCHI, 2006).

Na terceira fase (1990-1992), através da rede de recrutamento constituída pelos isseis, os nisseis começaram a entrar nesse movimento, aumentando o número de migrantes. Porém, 
já nessa fase eles planejavam, através de trabalhos monofuncionais, a obtenção de recursos financeiros, o que era difícil no Brasil, e a realização de algum projeto em terras brasileiras. Assim, a natureza do decasségui tornou-se positiva. Nesse mesmo período, além dos brasileiros, existia um número crescente de estrangeiros com vistos expirados, cuja maioria se concentrava em indivíduos vindos de países asiáticos, como China, Irã, Malásia e das Filipinas. Entretanto, os setores que incorporavam respectivamente esses trabalhadores ilegais e os brasileiros eram bem diferentes. Enquanto os brasileiros eram mais bem remunerados e encontravam trabalhos através dos canais institucionalizados, como agências de recrutamento, os trabalhadores ilegais dependiam de redes pessoais (HIGUCHI, 2006). Como referido acima, o aumento de trabalhadores ilegais levou o governo japonês à reforma da Lei de Controle de Imigração.

Além dos nisseis que já estavam trabalhando sob o status de "Cônjuges e filhos de japoneses", após a reforma da Lei os $\operatorname{sanseis}^{27}$ começaram a participar do movimento decasségui através de um novo status criado, "Residentes por longo período", e passaram a migrar com o objetivo de obter bens de consumo. Logicamente, as gerações posteriores têm menos características peculiares dos nikkei. Esses descendentes de japoneses, principalmente da terceira geração em diante, foram perdendo gradativamente as características fundamentais da cultura japonesa: usos, costumes, hábitos, etc. Conforme a mudança das gerações, a relação com a sociedade japonesa e com as empresas também se modificou (KAJITA, 2005a, p. $10-11)$.

A quarta fase (1993-1997) é caracterizada pela recessão econômica japonesa e pela mudança do mercado de trabalho. Não se pode ignorar o fato de que, apesar da recessão

\footnotetext{
${ }^{27}$ A permissão para a entrada de decasséguis até a terceira geração no Japão deu-se com a alteração da Lei de Controle de Imigração de 1990, pois, até então, era permitida a entrada somente aos de até a segunda geração.
} 
econômica dos anos 1990, o número da população brasileira tem aumentando constantemente.

O crescimento da população brasileira deve-se a: a) demanda de mão de obra contingencial; b) dispersão geográfica dos brasileiros. Mesmo no período da estagnação econômica, os brasileiros eram emrpegados no Japão, através de empreiteiras, nas condições vulneráveis. Eles eram uma mão de obra que poderia facilmente ser despedida (KAJITA 2005a), assim atendendo à oscilação da produção e substituindo os trabalhadores regulares.

Na quinta fase (1998 até os dias atuais), as principais características são: a mudança de gerações; o declínio da escolaridade; o problema da educação dos filhos. Ao se estabelecerem no Japão, os primeiros trabalhadores decasségui formaram redes sociais entre o país de origem e o de destino, reduzindo os custos e os riscos do ato migratório daqueles que pretendiam segui-los. Geralmente, essas redes servem para incentivar movimentos migratórios dos indivíduos menos qualificados e menos propícios à mudança de situação.

É constatado o declínio da escolaridade entre os trabalhadores decasségui que entram no Japão nessa quinta fase. Nesse caso, o declínio não foi resultado da entrada dos imigrantes da classe baixa, mas por causa da mudança de gerações, ou seja, os adolescentes começaram a participar no mercado de trabalho japonês. 


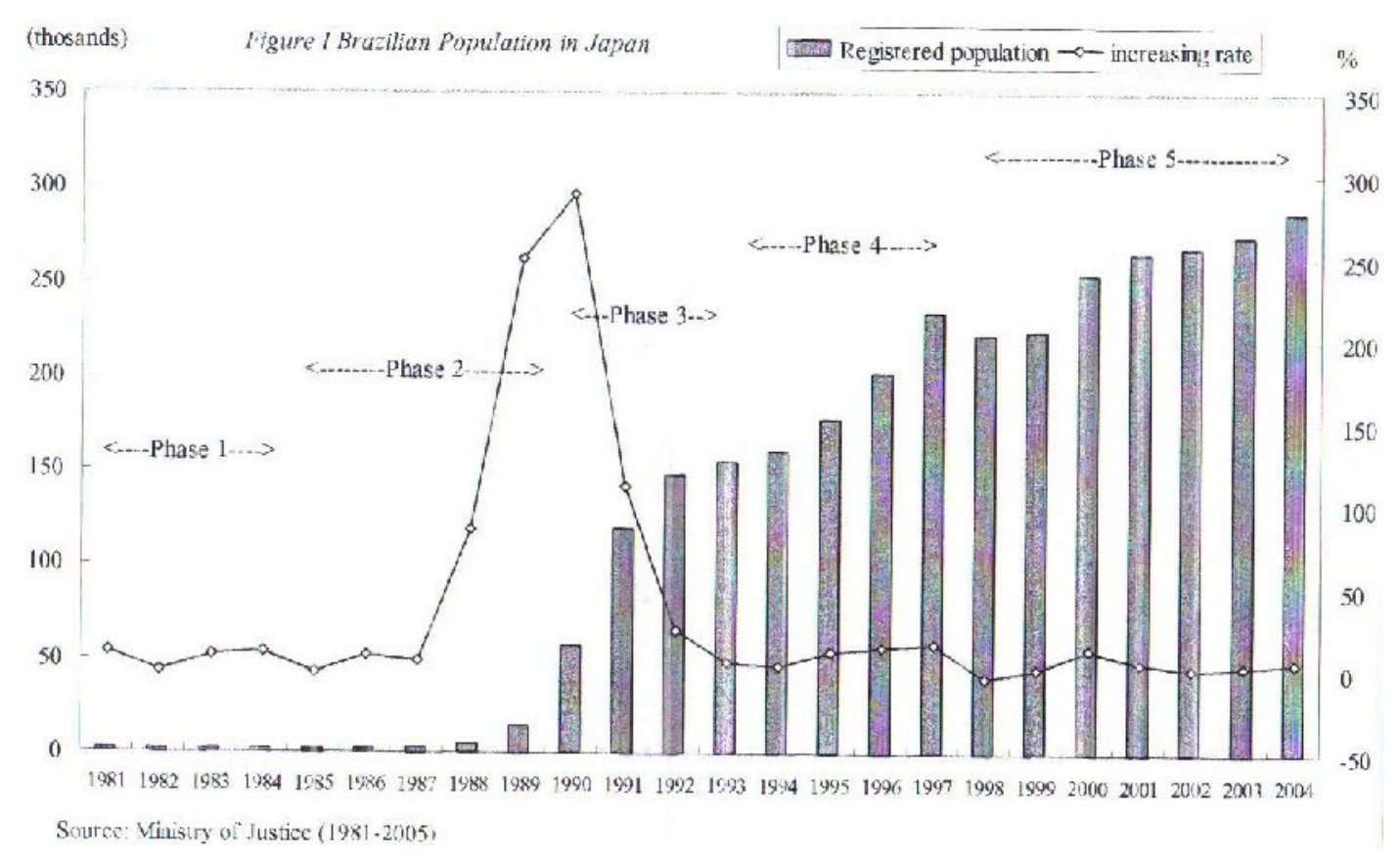

Tabela 4 - População Brasileira no Japão

\subsubsection{Mudança do mercado de trabalho no Japão}

Como referido acima, em 1990 a Lei de Controle de Imigração foi alterada e possibilitou a entrada e permanência para trabalho dos descendentes dos japoneses até a terceira geração. Na ocasião da abertura do mercado de trabalho japonês em 1990, a economia local estava em pleno processo da "Economia de Bolha". Pela falta absoluta de mão de obra, os brasileiros foram empregados como uma maneira de solucionar esta carência nos trabalhos monofuncionais, designados no Japão como 3K (condições): Kitsui (penoso); Kitanai (sujo) e Kiken (perigoso). Conforme Kajita (2005a, p. 7-9), os primeiros trabalhadores decasségui chegaram a ser contratados diretamente pelas empresas de grande porte. Kitagawa (1992) diz que, nessa época, surgiu um tipo de contratação “onde a empresa interessada ou um grupo de empresas colabora no recrutamento dos trabalhadores e a própria empresa os contrata diretamente" em cidades como Oizumi, Ota, Kiryu, na Província de Gunma, e Kakogawa, 
Província de Hyogo, etc. (Kitagawa, 1992, p. 115).

Porém, no decorrer dos anos 1990, o mercado de trabalho dos trabalhadores decasségui mudou significativamente. Durante o período da "Economia de Bolha", a sociedade japonesa inteira estava agitada pela prosperidade e, mesmo no mercado de $3 \mathrm{~K}$, onde os empregos costumam ser temporários e os riscos de desemprego eram altos, os contratos renovavam-se automaticamente, empregando os trabalhadores decasségui por longo período (KAJITA, 2005a, p. 8-11, 68-71). Em 1992, a "Economia de Bolha" decresceu drasticamente, e o Japão entrou num período de recessão que se prolongou por mais de dez anos. Nessa época, as empresas começaram com a reestruturação societária, dificultando a procura de emprego até dos próprios japoneses recém-formados (KAJITA, 2005a, p.8-11, 68-71).

No período "pós-Bolha", de um lado, os trabalhadores nacionais começaram a voltar ao mercado de trabalhos monofuncionais, ocupado até então pelos estrangeiros. Assim, além dos operários japoneses efetivos, aqueles que optaram pelos tipos pâto ou arubaito (ambos significam um tipo de trabalho temporário, "bico") começaram a trabalhar nas fábricas, concorrendo com os trabalhadores decasségui. Para as empresas, isso significou a multiplicação e a diversificação dos trabalhadores contratáveis (KAJITA, 2005a, p. 68-71).

E, mais, o governo japonês, tendo em vista o envelhecimento da população, determinou a prorrogação da idade-limite, de 60 para 65 anos, para a aposentadoria. Com isso, as empresas de grande porte começaram a adiar a saída dos empregados idosos ou a reempregar os aposentados (KAJITA, 2005a, p. 68-69).

Os trabalhadores decasségui, que eram substitutos dos nacionais para solucionar a falta urgente de mão de obra, assim como os autóctones que outrora recusavam trabalhos monofuncionais, e também os japoneses aposentados, todos voltaram ao segmento secundário de trabalho. E assim, surgiram mais opções de escolha para as empresas. Nesse contexto, as 
empresas davam espaço preferencial aos nativos, e as vagas menos disputadas aos estrangeiros (KAJITA, 2005a, p.70).

Com o término da "Economia de Bolha", o mercado de trabalho dos brasileiros tornou-se instável, e os contratos perderam a garantia da renovação. Ainda no contexto de recessão e de abundância de mão de obra, os valores dos salários reduziram, o que, naturalmente, deve ter causado uma jornada de trabalho mais longa para os trabalhadores decasségui (KAJITA, 2005a, p.68-71).

Como referido na seção 3.4, no Japão, no período pós-guerra (Segunda Guerra Mundial), existiu o "sistema empregatício japonês", caracterizado pelo emprego vitalício e salário escalonado por antiguidade. Tanno (2007) diz que esse sistema era um "mito", porque, na realidade, o chamado "sistema empregatício japonês" nunca existiu como uma corrente majoritária. De qualquer maneira, como ideologia o conceito ddeste sistema empregatício (a crença de que os esforços para obter o diploma universitário eram compensados pelo emprego estável, uma vez que a pessoa assim munida ingressasse no mercado de trabalho) prevaleceu. Dentro deste sistema ainda estava presente o dualismo. Neste prevalece uma estrutura dual composta dos funcionários regulares no lado privilegiado, e trabalhadores temporários no lado desfavorecido (TANNO, 2007, p.3).

Entretanto, segundo este amesmo autor, a globalização destruiu definitivamente tal crença (TANNO, 2007, p.3). Em particular, durante o período compreendido entre a segunda metade da década de 1990 e a primeira metade dos 10 anos iniciais deste milênio, o aparecimento de um crescente número de empregos irregulares (contingenciais) passou a chamar a atenção do público. A diminuição dos empregos regulares e o aumento dos empregos irregulares (contingenciais) vêm sendo debatido como um grande problema social (TANNO, 2007, p.11). 
De um lado, dentro de tal contexto, diferentes categorias de mão de obra (trabalhadores de contratação temporária, haken shain; trabalhadores empregados através de empreiteiras, ukeoi; trabalhadores tipo "bico", pâto ou arubaito; trabalhadores estrangeiros, etc.), vêm se expandindo rapidamente no mercado de trabalho. Para as empresas que as utilizam, pressupõe-se que esses trabalhadores teriam direitos trabalhistas distintos dos trabalhadores regulares e convencionais. Este entendimento acabou se tornando uma premissa para os empregadores. Nos países desenvolvidos, após a Segunda Guerra Mundial, os direitos trabalhistas dos trabalhadores regulares (previdência social, salário-mínimo, seguro-desemprego, etc.) foram estabelecidos, oferecendo-se uma rede de proteção para esses trabalhadores, que outrora foram tratados como se fossem objetos inanimados (KAJITA, 2005b, p. 7). Porém, para aqueles que têm trabalhos irregulares, frequentemente esses privilégios não seriam aplicados.

Por outro lado, as próprias empresas, tendo essa mão de obra diferenciada, realizam o enxugamento do seu elenco ou se lançam a novos ramos de negócios. Graças à tendência do crescimento de empregos irregulares (contingenciais) na década de 1990, as empreiteiras, as agências de mão de obra temporária e congêneres começaram a marcar presença dentro da corrente majoritária do mundo empresarial japonês (TANNO, 2007, p.3).

Desde a época da incipiente modernização da indústria japonesa, que ocorreu logo após a Restauração Meiji, a mão de obra fornecida pelas empreiteiras já vinha sendo utilizada em grande escala nas minas de carvão, estaleiros, usinas siderúrgicas e outros segmentos sujeitos a grandes flutuações na procura por trabalho. Também nas principais áreas industriais, na fase posterior à Segunda Guerra Mundial, tais como a indústria automobilística e a elétrica, as empreiteiras sempre atuaram como fontes de mão de obra para serviços monofuncionais. Mesmo assim, o aproveitamento das empreiteiras era mantido dentro de certos limites. Além 
disso, dentro do universo empresarial japonês, caracterizado pelo sistema de subcontratação de pequenas e médias empresas pelas maiores (ver seção 3.4.1), a mão de obra das empreiteiras era considerada problema das empresas subcontratadas. Recentemente, entretanto, com a prática cada vez mais frequente do enxugamento, inclusive nas grandes empresas, já não é mais raro ver o uso maciço de mão de obra de empreiteiras mesmo no nível das empresas que se posicionam no ápice da estrutura piramidal, composta pela empresa-mãe (empresa contratante) e pelos vários estratos de empresas subcontratadas (TANNO, 2007, p.5).

A propósito, em relação aos trabalhadores decasségui, há um índice de concentração excessivamente alto no mercado das empreiteiras (TANNO, 2007, p. 5). Na tendência do aumento de empregos irregulares no Japão, este fato causou inúmeros problemas, que serão explicitados posteriormente.

\subsubsection{Dualismo e função da empreiteira}

Como comentado na seção 3.4.1, no universo industrial japonês, no período pós-guerra, prevalece um dualismo que se caracteriza pela notória disparidade salarial entre a empresa-mãe (empresa contratante), de grande porte, e as subcontratadas, de pequeno e médio portes, que atuam sob a égide daquela (TANNO, 2007, p.59).

Essa disparidade salarial, determinada pela envergadura das empresas, prevalece não apenas por causa de uma mera disparidade entre os níveis de produtividade, mas também por causa de duas regras: a) o acesso ao mercado de trabalho das empresas-mãe (empresas contratantes) está aberto exclusivamente aos recém-graduados nas universidades; b) não havia migração de recursos humanos com experiência de trabalho entre empresas com relações comerciais e entre companhias pertencentes a um mesmo grupo empresarial, relação esta 
denominada keiretsu. Como resultado, a migração de recursos humanos das pequenas e médias empresas para a empresa-mãe (empresa contratante) era barrada. Assim, no sistema de emprego vitalício, a admissão em uma empresa não significava somente o ingresso de um indivíduo em um determinado mercado de trabalho. Como decorrência da primeira regra, no momento em que um indivíduo ingressava no mercado, ele já ganharia uma determinada posição dentro da hierarquia industrial. Como decorrência da segunda regra, a mudança de emprego do trabalhador significava necessariamente descer dentro da hierarquia. Consequentemente, o dualismo mantinha-se intacto (TANNO, 2007, p.59).

Tomando a indústria automobilística como exemplo deste dualismo, a empresa-mãe (empresa contratante) é conhecida pela implementação do chamado Toyotismo (Toyota Production System). Neste sistema de produção, o processo de montagem do veículo avança em conformidade com as instruções contidas na placa de controle, denominada kanban, que é emitida a jusante do processo. A essência do sistema consiste em minimizar o inventário em todos os níveis, inclusive os das empresas subcontratadas. Ao mesmo tempo, neste sistema as montagens dos veículos estão sincronizadas com os pedidos de compra dos clientes que chegam das revendedoras. Na etapa de planejamento da produção, faz-se uma meticulosa previsão da procura do produto no mercado para, então, montar o esquema de produção. Mas isso não significa que os pedidos dos clientes virão de acordo com os planos. De um lado há os modelos que vendem mais que o previsto, e por outro, há os que não chegam a atingir as expectativas. Entre as várias fábricas ocorrem sempre diferenças nas taxas de operação (TANNO, 2007, p.157). Sob tais circunstâncias, as empresas subcontratadas são obrigadas a fazer coincidir seu estado de operação com o da empresa-mãe (inclusive a utilização de mão de obra). Ou seja, elas precisam fazer coincidir sua procura por mão de obra com o estado diário de operação da empresa-mãe (empresa contratante). Assim sendo, a procura de mão de obra da 
empresa subcontratada deve ser determinada tomando-se em consideração sua situação atual e a projeção futura, assim como as da empresa-mãe (TANNO, 2007, p.64).

Nesse contexto, as empreiteiras passam a ajustar as ofertas e as procuras de mão de obra determinadas pelas relações das empresas. Em termos de relações trabalhistas, o serviço da empreiteira transforma o contrato trabalhista, que a empresa usuária deveria assumir, em um contrato de empreitada, oferecendo assim à empresa usuária uma liberdade que um contrato trabalhista jamais seria capaz de ofertar. É o contrato de empreitada que permite o recrutamento de mão de obra necessária somente no momento necessário (TANNO, 2007, p.64).

Apesar da presença da mão de obra dentro da sua própria fábrica, do ponto de vista da empresa usuária, o fato de ela se aproveitar dos serviços da empreiteira apenas significa uma consignação de serviços. Como resultado disso, torna-se possível recrutar a mão de obra exatamente necessária de conformidade com os altos e baixos no volume dos serviços.

O uso dos serviços da empreitada também permite a substituição do despedimento pela simples suspensão da consignação da tarefa (consignação do serviço), sendo para isto suficiente uma consulta e/ou acordo com a empreiteira contratada, dispensando assim os procedimentos exigidos para despedimento do trabalhador (TANNO, 2007, p.30). Dessa maneira, o uso da empreiteira proporciona vantagens para modificar, de forma flexível, o plano de recrutamento de recursos humanos ao ter que enfrentar situações inesperadas (TANNO, 2007, p.217).

Os trabalhadores nikkei não hesitam em aceitar trabalhos monofuncionais rejeitados pelos japoneses e, além disso, não recusam longas jornadas de trabalho. Na hora do aumento de produção, eles contribuem com a fábrica, digerindo, através de horas extras trabalhadas, as flutuações na procura de mão de obra necessária, que são por sua vez o reflexo das flutuações 
na produção. No momento da redução de produção, eles encarregam-se de absorver maiores níveis de flutuação, ao serem despedidos e afastados facilmente do local de trabalho no momento de crise (TANNO, 2007, p.217). Ou seja, como Corrêa Costa diz, os trabalhadores decasségui são utilizados como "um contingente de mão de obra que serve de $b u f f e{ }^{28}$ para as oscilações da indústria japonesa (CORRÊA COSTA, 2007, p.119).

Como decorrência da prolongada recessão econômica, a partir da segunda metade da década de 1990, os trabalhadores japoneses estão voltando aos empregos que vinham sendo ocupados pelos estrangeiros. Os trabalhadores estrangeiros estão sendo empurrados para segmentos ainda mais desfavoráveis no mercado de trabalho (TANNO, 2007, p.147), e sua posição se enfraquece (TANNO, 2007, p.30).

\subsection{Fenômeno do Invisible Residents}

Nesse novo esquema, Kajita (2005a) verifica um fenômeno chamado Invisible Residents, a fixação invisível de residência, com o significado da presença de trabalhadores estrangeiros, de forma que os moradores japoneses não possam ter o mínimo de contato com eles.

Esse fenômeno surge no seguinte processo: Como primeiro fator, destaca-se a jornada de trabalho excessivamente longa. Os trabalhadores decasségui entram no trabalho de manhã bem cedo e voltam ao alojamento após as horas extras. Esse ritmo de vida não incentiva a formação de contatos entre os trabalhadores decasségui e moradores da comunidade local, nem a participação em atividades comunitárias. Ou seja, os moradores japoneses sabem que os estrangeiros residem na região, mas quase nunca os veem e muito menos os conhecem.

\footnotetext{
28 Vide nota de rodapé $n^{\circ} 19$.
} 
Principalmente aqueles que pretendem fazer remessas para sua terra natal e por isso tendem ainda mais a ser uma presença invisível.

O segundo fator do processo é a forma de contratação dos trabalhadores decasségui. A maioria dos trabalhadores brasileiros trabalha nas grandes fábricas através de empreiteiras. Essas empresas, mesmo tendo know-how para contratar diretamente os trabalhadores estrangeiros, preferem tê-los por intermédio de empreiteiras. Isto porque a maioria dos trabalhadores decasségui que trabalham nas grandes fábricas é utilizada como mão de obra "conveniente" e disponível à demissão a qualquer hora. Por outro lado, as empresas pequenas querem os trabalhadores brasileiros para solucionar a falta constante de mão de obra. Assim, a possibilidade de a empreiteira mandar os brasileiros para as grandes empresas é mais alta. Porém, as empreiteiras precisam mandar e retirar os brasileiros, exatamente como os clientes exigem. Como a oscilação da produção e da demanda de mão de obra é muito grande, o número necessário de trabalhadores brasileiros muda completamente de uma hora para outra (HIGUCHI, 2006, p. 10).

Para sobreviver, as empreiteiras empregam a seguinte orientação: em primeiro lugar, tentam manter uma relação com o maior número possível de empresas/clientes. Logicamente, o objetivo primário disto é o aumento de clientela. Porém, simultaneamente, uma variada clientela pode minimizar o prejuízo que seria causado no momento de um despedimento repentino. Com a clientela variada, as empreiteiras podem transferir trabalhadores dispensados para outras fábricas. Geralmente, elas combinam serviços relativamente estáveis e instáveis. O típico serviço instável é o trabalho na fábrica de peças automobilísticas. Esses serviços são altamente remunerados, porém sua demanda é imprevisível, podendo os trabalhadores ser despedidos a qualquer hora. Os serviços estáveis seriam os trabalhos nas pequenas fábricas e nas indústrias alimentícias, cujas poucas vagas são mal remuneradas. Porém, estes podem 
servir como possíveis alternativas no momento de despedimento no serviço instável (HIGUCHI, 2006, p. 10).

Essa maneira de enviar os trabalhadores para fábricas é bem parecido com o sistema de entrega de peças no Toyotismo (the just-in-time parts-delivery system). Este sistema, que objetiva a redução ao máximo possível do inventário, causa também muitos problemas para as empresas subcontratadas, que precisam despachar seus produtos antecipadamente, mas estão proibidas de enviá-los antes da hora certa. O fornecimento dos produtos necessários na hora certa torna-se um ônus para essas empresas. Os brasileiros, que estão na lista de espera da empreiteira, estes são "enviados" para o local de trabalho, incorporando-se a esse sistema de just-in-time labor delivery. Neste esquema, são os próprios trabalhadores decasségui e as comunidades locais que têm que arcar com as consequências.

Enquanto não são enviados para o local de trabalho, os trabalhadores têm que estar à espera, pagando os custos normais de sua sobrevivência, mas não recebendo nada. Mais que isso, os brasileiros são frequentemente transferidos de uma fábrica para outra de acordo com as mudanças de demanda. Na situação instável de trabalho, torna difícil para os trabalhadores decasségui estabelecerem suas condições de vida a longo prazo (HIGUCHI, 2006, p.10).

A presença de trabalhadores que podem ser usados sempre que necessário pressupõe que eles existam dentro da comunidade local também quando não são necessários nas empresas. As comunidades locais, onde essas empresas estão localizadas, não são habilitadas a decidir quem pode ou não morar lá. A maneira de utilização de mão de obra decasségui e o consequente modo de vida dos trabalhadores nikkei, que dá prioridade para o trabalho, acabam causando alguns fatores de instabilidade nas comunidades locais: falta de relacionamento ou de contato cotidiano entre brasileiros e seus vizinhos japoneses; aparecimento de desempregados nos momentos de depressão, etc. 
Não se pode negar que os trabalhadores decasségui, no momento da partida para o Japão, visavam à obtenção de recursos financeiros no mais curto tempo possível. Sem a intenção de permanecer no país, naturalmente eles não investem no seu futuro no Japão. Essa atitude se reflete também nas empresas japonesas. De um lado, a falta de perspectiva de longa permanência dos trabalhadores decasségui no Japão resulta no não incentivo das empresas japonesas de oferecerem trabalhos permanentes. Por outro, o não incentivo à fixação, por parte do mercado japonês, e a consequente inexistência de consciência de permanência definitiva no Japão por parte dos trabalhadores decasségui, acarretam diversos problemas para os próprios trabalhadores decasségui, como, por exemplo, a educação dos filhos e a perda de qualificações profissionais subsequentes no decorrer do tempo. Isto, sem falar do problema Invisible Residents, segundo o qual a comunidade local não consegue reconhecer a exata presença dos trabalhadores decasségui, dificultando, assim, a introdução de medidas adequadas para integrá-los como seus membros.

A maneira como os trabalhadores decasségui estão sendo empregados pelas empreiteiras é viável somente porque esses fatores são negativos para os próprios trabalhadores, enquanto para as comunidades locais eles estão fora de consideração.

Um dos fatores causais da Migração Repetitiva, a ser tratada no capítulo 6, consiste neste problema do mercado japonês de trabalho para os trabalhadores decasségui.

\subsubsection{Sistema trabalhista que transcende as fronteiras}

Como já referido, a década de 1990 foi uma época em que os empregos irregulares (contingenciais) se expandiram no Japão. Tanno (2007) diz o seguinte:

O universo do sistema empregatício convencional do Japão, caracterizado pelo emprego vitalício e pelo escalonamento de acordo com a antiguidade, 
vinha se mostrando autossuficiente e autoconclusivo dentro das fronteiras japonesas. Porém, como decorrência da infiltração da mão de obra estrangeira, esse transformou-se num " "sistema trabalhista que transcende as fronteiras", ou seja, a mão de obra necessária é recrutada de forma transfronteiriça (TANNO, 2007, p.2).

Como comentado nas seções anteriores, os trabalhadores decasségui concentram-se num nível excessivamente alto no mercado das empreiteiras (TANNO, 2007, p.5). Pela Lei de Controle de Imigração, os trabalhadores nikkei não são sujeitos a restrições de atividades, teoricamente podendo escolhar qualquer emprego. Apesar de não possuírem direito de voto, da mesma forma que os demais estrangeiros, eles gozam de completa liberdade quanto à escolha da profissão e estão habilitados a receber o auxílio pecuniário para sustentação (seikatsu-hogo) e outras formas de seguridade social quando caem na pobreza (TANNO, 2007, p.5). Por outro lado, o governo japonês ainda continua adotando a postura oficial de não aceitar a mão de obra estrangeira não qualificada.

Em decorrência desses fatos, apesar de os trabalhadores nikkei realmente se concentrarem no setor das empreiteiras, que é o exemplo típico de uma situação em que a relação empregatícia prevalece em caráter predominantemente contingencial, este fato não é debatido como um problema concernente aos trabalhadores estrangeiros (porque isto é considerado uma consequência fortuita da liberdade de escolha da profissão dos trabalhadores decasségui) (TANNO, 2007, p. 30). E é ai que reside a situação de irregularidade relacionada com a aceitação maciça de trabalhadores brasileiros (TANNO, 2007, p.30), assim como a negligência das autoridades nacionais.

Também é verdade que caso as empreiteiras, que são os empregadores diretos dos trabalhadores nikkei, reconhecessem os direitos dos trabalhadores de conformidade com os preceitos, a margem de sobrevivência de tais empresas praticamente deixaria de existir. Mesmo que os trabalhadores decasségui façam horas extras, essas empreiteiras frequentemente 
não pagam adicionais, multiplicando somente o valor de horário normal pelas horas trabalhadas. Também é corriqueiro não observarem os 30 dias regulamentares de aviso prévio estipulados pela Lei das Normas Trabalhistas. Comparando com os trabalhadores regulares, esses pontso são prejudiciais para eles. Porém, graças a esses fatos é que elas podem fazer frente às súbitas flutuações nos volumes de produção das fábricas (TANNO, 2007, p.15).

Como as fábricas se interessam exclusivamente em recrutar o contingente necessário de mão de obra somente no momento necessário, estas conseguem se manter em conformidade com os requisitos da Lei de Padronização das Normas Trabalhistas (doravante simplesmente denominada como Lei das Normas Trabalhistas), mas ignoram se o fornecedor da mão de obra está ou não em conformidade com tais requisitos. As autoridades governamentais, por intermédio das Delegacias de Supervisão das Normas de Trabalho e das Agências Oficiais de Estabilização de Emprego (vulgarmente denominada como Hello Work), se empenham em identificar a situação dos trabalhadores estrangeiros nas fábricas. Entretanto, como o empregador dos trabalhadores estrangeiros é a empreiteira, haverá sempre trabalhadores que não aparecem nas estatísticas, por mais que se tente supervisionar as fábricas (TANNO, 2007, p.15).

Pode se dizer que a procura do tipo de mão de obra que pode ser utilizado de conformidade com as necessidades, a exemplo do contingente fornecido pelas empreiteiras, está aumentando cada vez mais. Tanno denomina esse modo de utilização de mão de obra como uma "estratégia empregatícia negativista", que funciona somente quando existem fatores negativos fora da lógica do mercado (atuando sobre os próprios trabalhadores e sobre as comunidades locais) (TANNO, 2007, p.169).

Porém, nessa forma de emprego existem perigos potenciais que não se tornaram visíveis até recentemente. Uma vez que a economia entra em dificuldades, esses trabalhadores, 
que são usados da mesma forma que as peças e componentes adquiridos, ou seja, somente quando são necessários, tornam-se desempregados, causando instabilidade nas comunidades locais. Já no início dos anos 1990, Miyajima (1993) comentou essa possibilidade, observando que, se se empregasse os trabalhadores decasségui sem lhes dar nenhuma oportunidade de formação ou de treinamento, eles acabariam formando uma estrutura mais baixa dos trabalhadores contingenciais, o que causaria futuros problemas (MIYAJIMA, 1993, p.70). E é exatamente isto o que está acontecendo a partir da segunda metade de 2008, com uma massa de trabalhadores decasségui desempregados por causa da crise mundial originada nos EUA.

Agora, chegou o momento para se rever a forma de sobrevivência das empresas japonesas, retornando ao ponto de partida de tudo, ou seja, reconhecendo-se que os trabalhadores decasségui não são peças, mas seres humanos. 


\section{CAPÍTULO 6 - MIGRAÇÃO REPETITIVA E PESQUISA DE CAMPO}

\subsection{Migração repetitiva}

A ideia inicial desta dissertação nasceu da pesquisa intitulada $O$ shuttle migration dos brasileiros residentes no Japão (zainichi burajirujin no shatoru iju), realizada para a obtenção de graduação em 2002, no Japão, sobre o fenômeno decasségui e o chamado Shuttle Migration. Na bibliografia reunida nessa época, o termo Shuttle Migration é denominado por Iyotani (2000) como "pessoas migrantes que vão e retornam entre locais de residência, no caso, situados em países diversos, repetindo muitas vezes esse "vai e volta"". Enorme foi o interesse por esse fenômeno de Shuttle Migration, daí a realização de um relatório a respeito deste movimento, no caso, entre o Brasil e o Japão, com base na pesquisa bibliográfica.

Em princípio, essa dissertação visava à continuação do mesmo tema, Shuttle Migration. Porém, pelas dificuldades na prática, acabou-se tratando, como tema principal, da questão da continuidade da imigração japonesa no Brasil com o movimento decasségui, e da influência dos fatores estruturais dos dois países para esses dois fenômenos contínuos.

Neste capítulo, faz-se uma breve consideração sobre o tema original Shuttle Migration, doravante chamado "Migração Repetitiva", através de dados bibliográficos e da pesquisa de campo. Para tanto, é necessário ter conhecimento do que é Migração Repetitiva.

\subsubsection{Definição de Migração Repetitiva}

Nos dias de hoje, a chamada globalização levou-nos ao desenvolvimento de transporte e de comunicação, o que facilita o "vai e volta" dos migrantes entre o país de origem 
e o de destino. No caso específico dos brasileiros residentes no Japão, o fato de serem migrantes legais fortalece essa tendência, pois praticamente não existe a limitação da saída e da (re)entrada, deixando a porta aberta para um deslocamento livre. ${ }^{29}$

A Migração Repetitiva dos trabalhadores decasségui é referida em várias pesquisas existentes, ${ }^{30}$ sob diversas designações, mas ainda não existe uma definição única e peculiar. Explicitamos aqui as denominações e definições utilizadas nas pesquisas existentes:

Conforme Iyotani (2001), o referido Shuttle Migration abrange, por exemplo, desde os empresários das empresas multinacionais que realizam o "vai e volta" como uma estratégia para a carreira, até os trabalhadores decasségui que são, na prática, obrigados a fazê-lo por variados motivos, como, por exemplo, a falta de opções.

Segundo Yamaguchi (2002), Return Migrant significa um contingente de pessoas que não consegue fixar seu local de residência em nenhum dos dois países e permanece na deslocação constante.

O conceito de Transmigrant (Cicle Migrant) de Mori (2000) significa uma modalidade de "viver", repetindo o vaivém, construindo, assim, a vida social de natureza transnacional e mantendo sempre o projeto de retorno para a terra natal.

Kitagawa (1992) conceitua um tipo de modalidade de vida dos trabalhadores decasségui de "vivência separada", no qual "os irmãos e irmãs da mesma família tendem a efetuar locomoção polarizada entre os dois países, que mantêm divisão de trabalho e intercâmbio entre si, assegurando uma posição de vida para si e vivendo separadamente entre o Brasil e o Japão" (KITAGAWA, 1992, p. 121).

${ }^{29}$ No Japão, atualmente, há uma tendência para alterar esse ponto. Por exemplo, nos planos governamentais que objetivam a promoção de regresso dos decasséguis desempregados, eles estão considerando a proibição "por um certo tempo" da reentrada daqueles regressados por intermédio do auxílio pecuniário do governo japonês. A definição ambígua do período proibido para reentrada est causando polêmicas.

${ }^{30}$ Corrêa Costa (2007); Ishi (2001b); Iyotani (2000); Kajita (2005); Mori (2000); Reis (2001); Yamaguchi (2002); e outros. 
Corrêa Costa, um diplomata brasileiro, estabeleceu o conceito de "migração circular" marcada pela natureza circular do movimento, pois, após o regresso para a terra natal, os ex-trabalhadores decasségui "se veem compelidos a novamente tentar a vida no Japão (...) seja pela dificuldade de readaptação ao cotidiano brasileiro (...) seja pela falta de preparo e orientação na aplicação de poupança" (CORRÊA COSTA, 2007, p. 75).

Consoante Kajita (2005a), os Repeaters são os que têm experiências de estada no Japão por mais de duas vezes, independentemente do ano da primeira chegada ao Japão.

Neste trabalho, define-se como Migração Repetitiva, no caso do fenômeno decasségui, a daqueles que foram como trabalhadores decasségui com o objetivo de trabalhar e de obter recursos financeiros, mas, após a tentativa de regresso e reinserção no Brasil, por algum motivo tiveram de retornar ao Japão. E, como a pesquisa foi feita no Brasil, naturalmente, foram considerados somente aqueles que já foram para lá por mais de duas vezes.

Assim como os migrantes decasségui, os atores da Migração Repetitiva são bastante diversos, e não se pode agrupá-los numa única categoria. Segundo a classificação de Mori (2000), existem pelo menos quatro tipos de migrantes repetitivos:

a) isseis: o primeiro grupo é constituído pelos migrantes japoneses, isseis, que imigraram para o Brasil, antes ou após a Segunda Guerra Mundial (MORI, 2000).

No início do movimento decasségui, na década de 80 , foram eles os pioneiros a emigrar para o Japão por duas razões. Primeiro, porque nessa época o Brasil passava por uma grave crise econômica, afetando principalmente as pessoas mais idosas, causando graves problemas de desemprego em massa. Segundo, porque, ante a inexistência de redes estabelecidas para a emigração, eram eles que detinham a facilidade para isso. Contudo, havia um senão: aqueles que possuíam o visto permanente teriam de abandonar o trabalho a cada 
dois anos no Japão, pois o visto permanente brasileiro no exterior expirava neste período;

b) "profissionalização de decasségui": o segundo grupo já é composto por nisseis, sanseis, etc. (MORI, 2000). Esse grupo, diferentemente do primeiro, foi composto, em sua maioria, por jovens solteiros ou casados, muitas vezes com cônjuges de origem não-japonesa. Houve um vaivém entre os dois países por razões diversas: insucesso em dar continuidade aos estudos no Brasil, tanto dos filhos como dos próprios trabalhadores; fracasso nos empreendimentos desenvolvidos no Brasil, com os recursos obtidos no Japão, gastando, assim, todos os recursos; dificuldades de adaptação no Japão e de readaptação no Brasil. O vaivém ocorrido por este segundo grupo foi denominado por Mori de "profissionalização de decasségui” (MORI, 2000);

c) empreendedores: o terceiro grupo é quase que uma exceção, pois trata-se de um número bastante pequeno. São os empreendedores que obtiveram muito sucesso como trabalhadores decasségui e resolveram manter algum empreendimento em ambos os países, repetindo o vaivém para controlar os negócios no Japão e no Brasil (MORI, 2000);

d) "regresso temporário": o quarto grupo é composto pelos nisseis e sanseis de meia-idade, que geralmente deixam filhos ou dependentes idosos no Brasil, ou que mantêm algum negócio familiar neste país. Esse grupo foi assim denominado porque periodicamente regressa ao Brasil, cuja duração de permanência aqui poderá variar de semanas até, no máximo, um ano. O procedimento de reentrada no Brasil ou no Japão ocorre temporariamente, daí a denominação por Mori, "regresso temporário" (MORI, 2000).

Estas classificações devem ser vistas com cuidado, vez que são feitas meramente para a conveniência de análise. Na realidade, há muitos casos que não podem ser determinados com uma ou outra dessas classificações. 


\subsubsection{Migração Repetitiva no caso do decasségui}

Para discutir sobre a Migração Repetitiva é imprescindível saber que nem todos os trabalhadores decasségui efetuam esse processo. Por exemplo, numa recente pesquisa realizada na província de Shizuoka (http://www.pref.shizuoka.jp/kenmin/km-140/jittaichousa.html), a porcentagem dos trabalhadores que preferem morar definitivamente no Japão encontra-se em torno de $19,10 \%$. Numa outra pesquisa realizada por Corrêa Costa, o mesmo índice foi de $10,90 \%{ }^{31}$

Na sua pesquisa, Corrêa Costa fez a seguinte pergunta: "Pretende voltar ao Brasil?", e sugeriu três respostas possíveis: "Sim", "Não", e "Ainda não se sabe". O autor estima que $28,64 \%$ da população decasségui, ou seja, 86.000 brasileiros, permaneceriam definitivamente no Japão. O número foi obtido somando-se a porcentagem das pessoas que responderam "Não" (10,90\%) com a metade daqueles que disseram "Ainda não sabe" (35,48\%). Para a outra pergunta aplicada, "Já voltou ao Brasil? (desconsidere férias)", 62,19\% responderam "Sim".

Não cabe aqui discutir a probabilidade desses números, que são citados apenas para se ter ideia do número de migrantes repetitivos. Segundo a pesquisa de Corrêa Costa, de uma maneira genérica pode-se dizer que aproximadamente $60 \%$ da população brasileira no Japão entraria no grupo de Migração Repetitiva. Porém, a diferença entre os trabalhadores decasségui residentes no Japão, os migrantes repetitivos e os retornados é sutil. ${ }^{32} \mathrm{Um}$ decasségui que hoje reside no Japão, poderá voltar ao Brasil futuramente, não se sabendo se

\footnotetext{
31 Supõe-se que essa diferença tenha se dado por causa das metodologias aplicadas. Na pesquisa de Shizuoka, os pesquisadores alertam que a preferência de permanência tende a ser maior por terem recolhido os dados através das escolas japonesas.

32 Outros itens da referida pesquisa da Província de Shizuoka também confirmam esse ponto: "retornar para o Brasil dentro de três anos", 15,1\%; "regressar para o Brasil dentro de 10 anos", 8,7 \%; "retorno para a terra natal após uma longa permanência no Japão", 39,6\%;" não sabe”, 13,7\%.
} 
ele conseguirá se fixar ou acabará retornando para o Japão, mas, em algum momento, por causa também da idade, ele terá que parar num dos países. Nesse sentido, o "ser migrante repetitivo" é algo transitório. O importante é ter em mente que essa repetição infinita do vaivém pode acarretar problemas irrecuperáveis, tais como: a perda de qualificações profissionais subsequente do decorrer do tempo, a desarticulação familiar, ou a perda da chance de educação, em se tratando principalmente de jovens.

Assim como os trabalhadores decasségui em geral, os componentes da Migração Repetitiva são indivíduos extremamente diversos em termos de idade, formação, características cultural e étnica. Portanto, não se pode considerá-los um grupo homogêneo. Mas, em termos de experiências no Japão, são praticamente iguais: trabalhadores monofuncionais.

No decorrer da pesquisa, questionam-se os seguintes aspectos: "Entre os trabalhadores decasségui, quem permanece no Japão? Quem repete o vaivém entre o Brasil e o Japão? Quem consegue se fixar no Brasil?”. Enfim, quais são os pontos diferenciadores que determinam a trajetória de cada migrante? Logicamente, além dos fatores estruturais, devem existir os pessoais.

Na seção seguinte, veremos os dados obtidos na pesquisa de campo para ter ideia sobre pontos.

\subsection{Relato da pesquisa de campo}

A pesquisa de campo foi realizada através de participações nas reuniões da ONG Grupo Nikkei de Promoção Humana e de entrevistas individuais com os participantes dessas reuniões. Os dados obtidos são bastante limitados em termos de número e de variedade, 
portanto, serão mostrados apenas para se ter ideia de como é a vida desses migrantes repetitivos.

A ONG Grupo Nikkei de Promoção Humana foi formada em 1999 por um grupo de amigos, descendentes de japoneses, sensibilizados pelo nível de desemprego que vinha aumentando assustadoramente na cidade de São Paulo. Sua atividade principal é reunir, a cada 30 dias, sempre na última quinta-feira do mês, desempregados, e promover uma palestra orientando essas pessoas sobre como elaborar um currículo e como se comportar diante de uma entrevista para conseguir colocação e/ou reinserção no mercado de trabalho, etc. Nessas palestras, entre os participantes havia uma parcela significativa de trabalhadores decasségui que haviam retornado ao Brasil. Daí nasceu um projeto voltado exclusivamente aos ex-trabalhadores decasségui.

O chamado projeto Tadaimá (cujo significado, cheguei em japonês) consiste em duas etapas: na primeira, com a presença de um coordenador, é realizada uma palestra a fim de conhecer as experiências de decasségui e os resultados obtidos. Após 15 dias, um novo encontro acontece, quando se realiza um tipo de dinâmica em grupo: cada retornado comenta sobre as experiências e atividades que realizou no Japão; quais são suas expectativas em permanecer no Brasil, etc. Nesses encontros, além dos conselhos dados pelos consultores voluntários, os participantes podem ter contato com outras pessoas na mesma situação, e, assim, trocar ideias e informações.

A pesquisa foi realizada quando da participação desse segundo encontro e, ainda, por meio de entrevistas realizadas com alguns dos seus participantes. Os entrevistados foram escolhidos entre as pessoas que confirmaram ter ido mais que uma vez ao Japão e se mostraram dispostas a receber a visita da pesquisadora. No total, foram feitas dez entrevistas com os participantes das duas reuniões, em sua maioria nas residências dos pesquisados. 
É importante enfatizar que essas entrevistas, baseadas nos questionários, foram feitas visando à coleta de dados qualitativos, e não para análise quantitativa. Apenas a partir dos dez casos não é possível obter alguma análise ou conclusão, portanto, dados da pesquisa de campo serão mostrados apenas para observação.

Abaixo, detalhamos as principais características dos entrevistados:

a) estado civil: Não se sabe se pela natureza do grupo no qual as pessoas se reuniram, mas a maioria se declarou solteiro. Houve apenas dois casos de divorciados e de três casados, destes, dois formam um casal e, portanto, foram entrevistado juntos.

b) faixa etária: Predominantemente composta pelas pessoas por volta dos 30 anos (1 pessoa da faixa de 20 anos; 6 de 30 anos; 2 de 40 anos; 1 de 50 anos).

c) sexo: Quase todos os entrevistados são do sexo masculino; apenas uma mulher, e sua entrevista aconteceu porque seu marido estava participando na reunião. Esta predominância pode ser explicada pelo fato de a reunião da referida ONG estar sendo realizada para a procura de emprego pelos ex-trabalhadores decasségui, e o maior número de participantes é de homens.

d) ascendência: Este quesito baseia-se numa definição utilizada pela Pesquisa da População de Descendentes de Japoneses Residentes no Brasil, o mais novo dos dois recenseamentos realizados em escala nacional (em 1958 pela Comissão de recenseamento da colônia japonesa e em 1988 pelo Centro de Estudos Nipo-Brasileiros) a respeito de nikkei no Brasil, que registrou as informações sobre os variados aspectos.

Nela, entende-se por descendentes de japoneses:

Todos os imigrantes japoneses e os japoneses residentes no Brasil com permanência superior a 3 meses e seus descendentes, sendo, pois, incluídos todos aqueles residentes no território brasileiro que tenham pelo menos um ascendente direto nas condições referidas (CENB, 1990, p. 16).

Portanto, tendo pelo menos um japonês entre os seus antepassados, a pessoa já seria 
considerada como descendente, independente do grau de miscigenação. Entre os dez entrevistados, apenas dois são mestiços, e o restante descendentes diretos.

e) geração: Neste quesito adotou-se o mesmo critério da pesquisa acima referida. Nela, a geração é assim definida:

O imigrante japonês é considerado da $1^{\text {a }}$ geração (issei). O filho nascido de pai e mãe da $1^{\mathrm{a}}$ geração é considerado da $2^{\mathrm{a}}$ geração (nissei) e o filho nascido do casal de nissei é dito da $3^{\text {a }}$ geração (sansei). Os descendentes de japoneses nascidos de casal de gerações diferentes terão a geração definida acrescentando-se uma unidade à numeração original da geração mais avançada dos pais. Por exemplo, o filho nascido de pais da $1^{\mathrm{a}}$ e $2^{\mathrm{a}}$ geração será, segundo esta definição, da $3^{a}$ geração. Outrossim, tendo em vista a existência de numerosos descendentes miscigenados de origem japonesa, adotou-se também divisões em subcategorias de "puro" e "miscigenado". Assim, o filho nascido de japonês ( $1^{\mathrm{a}}$ geração) e não japonês será da $2^{\mathrm{a}}$ geração-miscigenado, e o filho nascido do casal de nissei-puro e não japonês será um descendente de origem japonesa da $3^{\mathrm{a}}$ geração-miscigenado. Este conceito é independente do conceito de identidade referente à etnicidade, onde o indivíduo se autoidentifica, ou tem consciência de sua ascendência étnica. Não tem, pois, nenhuma correlação com os aspectos culturais, são índices atribuídos exclusivamente em função da posição ocupada dentro da linhagem genealógica (CENB, 1990, p.30).

Curiosamente, a geração dos entrevistados se dividiu em duas partes iguais, ou seja, 5 pessoas da $2^{\mathrm{a}}$ geração e outras 5 da $3^{\mathrm{a}}$, incluindo os dois mestiços nesta segunda categoria.

f) escolaridade: Este quesito mostrou-se variado: 3 pessoas de nível superior completo; 4 de nível superior incompleto; 2 de nível de segundo grau completo; 1 de nível de primeiro grau completo.

Passaremos agora aos resumos, breves comentários, sobre o perfil dos dez entrevistados e tabelas de dados, constantes dos Anexos, dos seguintes itens: dados demográcios (Tabela 1); ocupação anterior e motivos da ida ao Japão (Tabela 2); retorno ao Brasil (Tabela 3); destino da renda adquirida no Japão (Tabela 4); pontos positivos e negativos da experiência como decasségui (Tabela 5); tempo de permanência no Japão e no Brasil (Tabela 6).

As experiências profissionais no Japão não estão sendo comentadas aqui porque, 
praticamente, todas são iguais: trabalhos nas fábricas. A única exceção foi o caso do senhor $\mathrm{n}^{\mathrm{o}}$ 1, R. O., que era encarregado para tomar conta de outros brasileiros (tantôsha). Pode-se dizer que, no seu caso, a experiência foi útil para que, posteriormente, abrisse uma agência de trabalhadores decasségui no Brasil. Porém, como será visto mais adiante, este empreendimento não deu certo.

\section{Breves comentários sobre o perfil dos dez entrevistados}

1) R. O. - Um senhor na faixa dos 40 anos, descendente direto da $2^{\mathrm{a}}$ geração, casado. Antes de partir pela primeira vez para o Japão, em 1989, trabalhava como técnico de processamento de dados num banco particular. Chegou a entrar na faculdade, mas não a concluiu pelas dificuldades de conciliar estudo e trabalho ao mesmo tempo. O motivo da primeira ida, com contava 29 anos, foi a obtenção de recursos para poder comprar sua casa própria. Após alguns retornos de curto período a passeio, R. O. permaneceu por dois anos (de 1993 até 1995) no Brasil para tentar se fixar. Pela indicação de um amigo, encontrou um emprego de gerente numa loja de confecção num shopping. Porém, essa loja fechou, e como ele não conseguiu outro emprego no Brasil, partiu novamente para o Japão. De 1995 até 2002, continuou o vaivém, retornando apenas nas férias. Nesse período, divorciou-se e se casou novamente (sua esposa é a entrevistada $n^{0}$ 10, D. O.). Em 2002, retornou ao Brasil com a esposa, por motivos familiares (doença da mãe), e abriu uma agência de emprego para trabalhadores decasségui (no início em Mogi das Cruzes, depois em São Paulo). Os ganhos dessa agência, no início, eram suficientes para se manter, mas, pela falta de candidados, R. O. viu-se obrigado a encerrar suas atividades. No momento da entrevista, a agência já havia sido fechada e o casal vivia de poupança. De 2002 a 2003, R. O. foi, pela última vez, para o Japão, 
apenas para acumular mais dinheiro. Os recursos obtidos foram destinados para a compra de imóveis (alguns estavam sendo vendidos para o próprio sustento) e para a poupança. Como pontos positivos, R. O. cita: obtenção de recursos, cultura e amigos. Como negativos: a perda de qualidade profissional, envelhecimento e divórcio do primeiro casamento.

Pode-se ver que este entrevistado praticamente gastou dez anos (dos 30 aos 40 anos de idade) nesse vaivém, ficando desatualizado na sua profissão. Este caso poderia entrar na categoria de "profissionalização de decasségui", citada na seção 6.1.1. No momento da entrevista, ele estava tendo dificuldades para encontrar emprego no Brasil. Em contatos posteriores, confirmou-se que ele conseguira se empregar.

2) P. O. - Um senhor na faixa dos 50 anos, descendente direto da $2^{\mathrm{a}}$ geração, solteiro. P. O. foi pela primeira vez ao Japão em 1991 (38 anos de idade) porque a empresa japonesa em que ele trabalhava como assistente contábil fechou, ele obteve contato para poder trabalhar no Japão. A intenção inicial era ficar dois anos para conhecer o Japão, porém, P. O. se acostumou e acabou prolongando sua estada. Durante 14 anos ele continuou o vaivém, retornando apenas para visitar a família. Após perder o pai, desistiu de voltar ao Japão novamente, por não querer deixar sua mãe sozinha. Através da indicação de um amigo, ele começou a trabalhar como assistente de escritório numa microempresa nacional (sem registro). Os recursos obtidos foram destinados para a compra de uma casa no interior de São Paulo. Como ponto positivo, P. O. cita: obtenção de recursos, e, como negativo, a desatualização na profissão.

Esse senhor teve sorte em arrumar um emprego no Brasil, ainda que sem registro em carteira. Além disso, o fato de ele viver na casa da mãe também é um dado favorável, porque não precisa se procupar com a compra ou aluguel de um imóvel para si mesmo.

3) J. I. - Um senhor na faixa dos 40 anos de idade, descendente direto da $2^{\text {a }}$ geração, solteiro. Antes da primeira ida, chegou a trabalhar como auxiliar administrativo em um 
escritório. Foi para o Japão, pela primeira vez, no mês de julho de 1990 (24 anos de idade), com o objetivo de guardar dinheiro, porque não tinha muitas oportunidades de fazer isto no Brasil. Após a estada de um ano no Japão, regressou com a intenção de aqui ficar, porque o Japão era muito diferente. Através da indicação de um conhecido, chegou a trabalhar em um hotel, cujo proprietário era de origem japonesa, como recepcionista. Porém, aqui percebeu que não tinha muita expectativa de futuro e partiu novamente para tentar acumular dinheiro no Japão. Foi então que iniciou o vaivém, de 1993 até 1999. Após o quarto retorno (32 anos de idade), J. I. investiu seu dinheiro em uma pequena empresa franqueada na área de seguro de saúde, porque não aguentava mais o ritmo estressante de trabalho no Japão. Ele passou a vender planos de saúde, mas não deu certo, e acabou perdendo todo o investimento e ficando endividado. De 2004 a 2006, foi pela quinta vez para o Japão, novamente objetivando obter mais recursos, para a liquidação das dívidas e a compra de um imóvel. Novamente retornou, porque a vida no Japão estava muito cansativa, e comprou um terreno perto da casa do pai, na cidade de São Paulo. Porém, logo após a volta, sofreu um acidente e ficou de repouso por mais de um ano. Desde então, não trabalha, só faz "bico" como vendedor ambulante, e vive do alugel de um imóvel que possui. O recurso obtido foi destinado ao investimento na empresa, compra de imóvel, liquidação de dívidas, custos hospitalares e sustento. Como ponto positivo, J. I. cita o dinheiro fácil, e como negativo, muito trabalho, clima e disciplina rígida.

Destacou-se propositadamente o exato mês da primeira partida (julho de 1990) porque, um mês antes (junho de 1990), a reforma da Lei de Controle de Imigração japonesa entrou em vigor. Na primeira experiência, o entrevistado foi com amigos para a cidade de Oizumi. Ou seja, ele pode ser considerado um exemplo típico daqueles que partiram em massa no ano de 1990. Este pode ser considerado um caso típico de vaivém entre o Brasil e o Japão. A pessoa, não podendo resistir à tentação do dinheiro fácil, repete a ida e a volta, mesmo 
contrariando sua própria vontade

4) M. A. - Um jovem senhor na faixa dos 30 anos, descenente direto da $3^{\text {a }}$ geração, divorciado. M. A. chegou a trabalhar como assistente contábil numa empresa. Em 1998, aos 24 anos de idade, foi, pela primeira vez ao Japão com o objetivo de obter recuros para custeio dos gastos familiares (remessa) e recursos para sua educação. Após o primeiro retorno, para a continuação dos estudos e restaurar o negócio familiar, chegou a trabalhar na área comercial, mas foi novamente para o Japão a fim de juntar mais dinheiro para o seu casamento. Após o segundo retorno, voltou a trabalhar no negócio familiar (comércio), casou-se e se divorciou. Foi pela terceira vez para o Japão com o objetivo de juntar dinheiro para compra de imóvel, estudos e abertura de um negócio próprio. No momento da entrevista, ele ainda não estava trabalhando no Brasil, e vivia à custa do apoio dos pais. Porém, não pretendia mais ir para o Japão, ao invés disso, tencionava poder criar raízes e iniciar uma carreira no Brasil. O recurso obtido foi destinado para a reestruturação do negócio familiar, ajuda nas despesas médicas da família, compra de imóvel e empreendimento. Como pontos positivos, M. A. citou: conquista de amigos, conhecimentos pessoais e desafio, e, como negativos: o fato de não poder ficar com família, não criar raízes e a perda de identidade.

5) E. K. - Um jovem senhor na faixa dos 30 anos, descendente direto da $2^{\text {a }}$ geração, solteiro. No momento da primeira partida, em 1994, E. K. frequentava o segundo grau. Seu pai sofreu acidente, e a família precisava liquidar dívidas por causa do custo hospitalar, por isso ele foi para o Japão trabalhar com o pai já recuperado e um irmão, deixando sua mãe e suas irmãs menores no Brasil. Após três anos, conseguiu liquidar a dívida da família e regressou para concluir o estudo (curso técnico de Química). Após concluir o curso no Brasil, conseguiu emprego como técnico de química numa empresa multinacional. Mais tarde, começou a trabalhar na prefeitura de uma cidade da Grande São Paulo, e terminou a faculdade de Letras. 
Como o ambiente de trabalho (serviço público) estava fazendo mal para sua saúde mental, E. K. resolveu ir para o Japão novamente, a fim de ganhar dinheiro para poder estudar inglês e música (trombone) na Austrália. Porém, no Japão, percebeu que, ali permanecendo, acabaria ficando "igual aos outros decasséguis", e voltou, "pela última vez", para tentar a sorte no Brasil e, também, porque havia problemas familiares no Brasil. No momento da entrevista, fazia um mês que E. K. tinha voltado. Ainda não estava trabalhando, mas em busca de uma nova atividade. Os recursos obtidos na primeira ida foram destinados para liquidação de dívidas da família; o da segunda, para pagamento da passagem aérea de ida e volta. Como pontos positivos, E. K. cita: aprendizagem de uma cultura diferente (disciplina, responsabilidade, dedicação ao trabalho, controle de qualidade, etc.) e a independência; e, como negativos: solidão que se sente pelo fato de estar num país completamente diferente do seu e o excesso de trabalho.

Neste caso, o fato de ele ter ido para o Japão muito novo (18 anos na primeira vez) foi favorável para sua reinserção no Brasil. Mas, pela entrevista, não pudemos saber como foi a volta pela segunda vez.

6) F. S. - Um jovem na faixa dos 20 anos, mestiço da $3^{\text {a }}$ geração, solteiro. No momento da primeira ida, F S. contava 11 anos, foi levado, com a família, pelo pai, que optou pela ida pretendendo "dar uma vida melhor para os filhos". Durante os quatro anos de estada no Japão, F. S. terminou o ginásio público (chûgakko). Como o pai arranjou trabalho de promotor de eventos no Brasil, a família inteira regressou. Com 15 anos, permaneceu no Brasil por aproximadamente um ano, fazendo "bico" como vendedor de loja. Depois, partiu para o Japão para poder viver sozinho. Aos 26 anos, regressou, porque não queria para si aquela vida que os colegas tinham no Japão. No momento da entrevista, vivia com a economia que havia obtido Japão, investindo em cursos profissionalizantes (de programação e de inglês). O recurso 
obtido foi destinado, em sua grande parte, para diversões e passeios no Japão, e para estudos no Brasil. Como pontos positivos, F. S. cita: muitas diversões e procura fácil de emprego no Japão; e, como negativo, o fato de tudo ser demasiadamente regularizado.

7) O. A. - Um jovem senhor na faixa dos 30 anos, descendente direto da $3^{\text {a }}$ geração, solteiro. Antes da primeira ida, ajudava no trabalho da família (agricultura e feira). Com 18 anos foi, pela primeira vez, objetivando a aquisição de um automóvel, terreno e recurso para uma nova atividade. Dois anos depois, retornou para o Brasil com o recurso obtido, e foi trabalhar em diversos empregos (táxi, feira, vidraçaria, etc.). Posteriormente, comprou um restaurante, porém, após alguns anos, teve que fechá-lo pro falta de movimento. Foi para o Japão, pela segunda vez (26 anos de idade), para acumular uma quantia suficiente para um novo investimento; retornou para o Brasil e comprou uma loja de revelação de fotos. No momento da entrevista, estava vivendo razoavelmente bem com o lucro dessa loja. O recurso obtido no Japão foi destinado para aquisição de bens e investimento em empreendimentos. Como pontos positivos. O. A. cita: a obtenção de recurso, o fato de conhecer a terra dos antepassados, a independência e o dinheiro rápido. Como negativos: além do estresse e da depressão, o fato de estar sempre cansado, de ficar defasado em relação ao Brasil e de se acostumar com o dinheiro fácil no Japão.

Este foi um caso raro de alguém que conseguiu sua reinserção no mercado de trabalho brasileiro.

8) N. M. - Um jovem senhor na faixa dos 30 anos, descendente direto da $3^{\text {a }}$ geração, divorciado. N. M. era autônomo na agricultura. Aos 19 anos, foi para o Japão a fim de ganhar dinheiro para a aquisição de um automóvel e também para conhecer o Japão. Como seus objetivos foram alcançados, regressou para o Brasil e voltou a trabalhar na agricultura. Depois do casamento, foi novamente ao Japão visando recursos para compra de uma casa própria (27 
anos). Após o segundo retorno ao Brasil, começou novamente a trabalhar na agricultura. No momento da entrevista, estava indeciso se oltaria ao Japão, comentando que poderia partir novamente se o negócio do Brasil não desse certo. O recurso obtido foi destinado para a aquisição de bens, poupança e turismo. Curiosamente, N. M. não citou nenhum ponto positivo, e, como negativos: o ritmo de trabalho rígido e a falta de perspectiva de local fixo.

9) M. S. - Um jovem senhor na faixa dos 30 anos, mestiço da $3^{\text {a }}$ geração, casado. M. S. foi o único entrevistado que tem filhos. Antes da primeira partida, chegou a trabalhar como office boy, mas sem registro. Aos 15 anos, foi para o Japão com os primos, apenas pela curiosidade de conhecer o Japão. Apesar da intenção de ficar por muito tempo, começou a ficar com saudade, voltou e se casou com a namorada que ficara no Brasil. No Brasil, não chegou a ter um trabalho fixo, só fazia "bico" vendendo ovos na feira (o negócio da família). Como a situação do Brasil estava difícil, aos 23 anos M. S. partiu, junto com a família, com a intenção de ficar, pelo menos, cinco anos no Japão. Porém, após três anos, todos tiveram que voltar porque seu pai adoeceu. Após o segundo retorno, ele começou a trabalhar como balconista no mercado, vendedor no shopping, e, depois, fez um curso de vigilante e, por indicação do próprio curso, começou a trabalhar numa empresa de segurança privada. No momento da entrevista, fazia seis meses que estava desempregado, e estava pronto para ir novamente ao Japão junto com a família (esposa e filhos) caso não conseguisse emprego no Brasil. O recurso obtido foi destinado para o sustento da família (inclusive as crianças). Como pontos positivos, M. S. citou: o encontro fácil de emprego e o bom salário. Como negativo, M. S. citou apenas o clima ruim do Japão.

10) D. O. - Uma jovem senhora na faixa dos 30 anos, descendente direta da $2^{\text {a }}$ geração, casada. D. O. foi a única entrevistada feminina, esposa do entrevistado n- 1, R. O. Antes da primeira ida, trabalhava como corretora de seguros. Aos 27 anos, foi para o Japão a 
passeio, com a intenção de ficar apenas seis meses. D. O. acabou prolongando sua estada porque gostou e se acostumou no Japão, permanecendo lá por seis anos. Durante esse período, ela regressou algumas vezes só para poder visitar a família (esses regressos não estão registrados na Tabela 6). Em 2002, ela perdeu o pai e, como ficou com pena de deixar sua mãe sozinha, retornou definitivamente. Após a volta, matriculou-se na faculdade, ao mesmo tempo em que ajudava no negócio do marido (agência de trabalho). No momento da entrevista, D. O. estava terminando a faculdade e procurando emprego na sua área (enfermagem). O recurso obtido no Japão foi destinado, em grande parte, aos passeios dentro e fora do Japão. A pouca sobra foi aplicada nos estudos no Brasil. Como pontos positivos, D. O. citou: o fato de ter conhecido o marido e a experiência de viver no Japão; como negativos: o fato de não poder trabalhar fora da fábrica, e o desgaste físico muito maior por excesso de trabalho no Japão.

O regresso para escola ou a continuação dos estudos são opções úteis para a reinserção no mercado de trabalho brasileiro. $\mathrm{O}$ caso desta jovem senhora deixa este ponto claro.

\section{CONSIDERAÇÕES FINAIS}

A partir dos fatos apresentados nos capítulos anteriores, podemos entender que, no movimento decasségui iniciado no final dos anos 1980, os trabalhadores brasileiros sempre vêm sendo utilizados como uma mão de obra não qualificada. Eles nem sempre eram mal remunerados, pois havia época em que os salários chegavam até 350 mil ienes ou mais, incluindo horas extras. Considerando a taxa de câmbio no final de 1989, aproximadamente US\$ $1=¥ 110$, esse valor corresponderia a cerca de 3200 dólares ou mais (edição $\mathrm{n}^{\circ} 494$ do 
Jornal Nippo-Brasil, um jornal destinado para ex-trabalhadores decasségui no Brasil, doravante simplesmente denominado como JNB). No início do movimento, tendo em vista o contexto da falta de mão de obra, algumas empresas japonesas chegaram a contratar diretamente os brasileiros, como aconteceu com um grupo de empresários das cidades de Ôta e Ôizumi (ambas na província de Gunma). Mesmo assim, o fato de eles desempenharem trabalhos monofuncionais não mudou até hoje.

No caso da imigração, frequentemente, os motivos econômicos têm influência mais forte que os motivos políticos ou religiosos. No movimento decasségui, porém, a vida inteira dos trabalhadores tem tendência de depender de seus empregadores, as empreiteiras. Porque, cerca de $80 \%$ da população brasileira no Japão se dedicam ao trabalho do setor manufatureiro (NINOMIYA, 2003, p. 30). Muitos deles são empregados através de empreiteiras que enviam os trabalhadores nas fábricas de empresas contratantes. Desde o início do fenômeno decasségui, essas empreiteiras têm oferecido diversas facilidades para a vida dos trabalhadores brasileiros. No começo, muitos deles não tinham condições de viverem sozinhos, pela falta de conhecimento da língua japonesa ou dos costumes. Além disso, a procura de moradia para estrangeiros no Japão é difícil porque os proprietários ou as imobiliárias costumam exigir fiadores japoneses. As empreiteiras arranjavam as moradias e as pessoas, que sabiam japonês e português, sendo encarregadas para tomarem conta desses trabalhadores. Ou seja, as empreiteiras ofereciam uma infraestrutura que possibilitasse a sobrevivência dos brasileiros sem eles saberem a língua japonesa. Em termos de estabilidade de emprego, os contratos mantidos entre as empreiteiras e as empresas contratantes costumavam ter prazos curtos para poder atender à flutuação de produção. Logicamente, nem todos os brasileiros dependiam das empreiteiras. Nessa situação, porém, muitos deles, no momento de despedimento, perderiam moradias e apoios, sendo deixados num país estranho sem saberem o seu idioma. 
Após a crise oriunda dos EUA na segunda metade de 2008, a indústria japonesa de produção sofreu uma grande crise. Citando apenas como exemplo, as 12 principais montadoras japonesas de automóveis demitiram cerca de 14 mil trabalhadores pela queda da demanda (edição $\mathrm{n}^{\circ} 490$ do JNB).

Nessa situação, os trabalhadores brasileiros vêm sendo afetados seriamente, perdendo empregos. Segundo a imprensa, em algumas cidades, como Konan e Nagahama (ambas na província de Shiga), 40\% dos trabalhadores latinos estão desempregados (edição $\mathrm{n}^{\circ} 497$ do $\mathrm{JNB})$.

$\mathrm{Na}$ vida dos trabalhadores decasségui, onde os fatores econômicos prevalecem, os maiores prejudicados são filhos menores que lá se encontram. Quando os pais trabalham dez ou doze horas por dia, os filhos são deixados de lado. O horário das escolas japonesas costumam ser até cerca de 3 horas da tarde, depois disso, os pais não podem saber o que os filhos estariam fazendo. As escolas brasileiras no Japão frequentemente tomam conta dessas crianças até a volta dos pais, porém, suas mensalidades são caras. Ultimamente, muitas das crianças brasileiras têm saído dessas escolas brasileiras porque os pais desempregados não podem arcar com o custo escolar.

Quando a decisão dos pais entre a permanência no Japão ou o regresso para o Brasil não foi tomada, a sua orientação educacional torna-se ambígua, deixando o processo educacional dos filhos incompleto (podemos ver isso no caso do entrevistado ${ }^{\circ} 6$, F.S.).

Desde que os problemas recentes dos brasileiros surgiram no Japão, os governos central e locais, os grupos privados e outros têm tomado diversas medidas para apoiar os brasileiros: a realização de aula de japonês, porque agora os brasileiros tomaram consciência de que o conhecimento da língua japonesa é imprescindível para arranjar emprego; a doação de alimentos e o oferecimento de subisídios para escolas brasileiras que estão em dificuldades 
financeiras por causa da perda de alunos; também, o oferecimento de alimentos para as pessoas desempregadas; o oferecimento de vagas de trabalhos temporários pelos governos locais (não só para os brasileiros, mas também para os japoneses desempregados); o curso de preparação para recolocação; o oferecimento de auxílios pecuniários para regressarem ao país, etc. Porém, não podemos dizer que essas medidas são suficientes para resolver problemas de todos os brasileiros desempregados.

Essas crianças e jovens teriam potências de se tornarem recursos humanos valiosos para os dois países. De fato, mais de 100 jovens brasileiros já ingressaram nas universidades japonesas, e alguns dos retornados estão nas universidades brasileiras. Tendo em vista que o primeiro universitário japonês no Brasil só apareceu no início da década de 1930, depois de cerca de 25 anos da imigração japonesa no Brasil, podemos dizer que o resultado atingido pelos filhos dos trabalhadores decasségui é notável.

Além disso, como subproduto do fenômeno decasségui, tem aparecido um grande contingente de pessoas bilíngues (japonês-português). Esse fato é óbvio quando vemos que cada província ou município, com concentração de brasileiros, tem tradutores/intérpretes em prefeituras, escolas, hospitais, delegacias de polícia, etc.

De um lado, ao considerarmos que as tendências do envelhecimento da popualção japonesa e da redução de número de filhos se tornam uma questão muito grave no Japão, podemos prever que a procura de trabalhadores decasségui voltará a aumentar num futuro próximo.

Por outro lado, na era da globalização, as diversas facilidades, como as de comunicação ou de transporte, permitem um movimento mais intenso entre os países de origem e de destino. Portanto, futuramente, a comunidade brasileira poderá ter uma conexão mais forte com a comunidade nipo-brasileira, tornando a relação entre os dois países ainda 
mais próxima.

Durante mais de 50 anos, o governo japonês, através do seu Ministério de Educação, tem oferecido bolsas para universitários brasileiros. Os ex-bolsistas que obtiveram os conhecimentos da cultura japonesa têm contribuído muito para aproximar os dois países em diversas áreas, como as de pesquisa e de ensino, e outros ramos de conhecimento. Na nova fase da relação nipo-brasileira a vir agora, essas crianças que incorporaram as culturas japonesa e brasileira poderiam desempenhar um papel semelhante dos ex-bolsistas.

$\mathrm{Na}$ atual situação da crise, muitas dessas crianças passam por dificuldades, sendo obrigadas a sairem das escolas brasileiras ou a retornarem para o Brasil com os pais desempregados. Daqueles que ficaram no Japão, uma parte irão para as escolas japonesas. A outra parte irão para as escolas no Brasil. De qualquer maneira, eles enfrentarão os problemas de adaptação que chegam levar meses ou até anos. Mesmo não tendo dados, podemos imaginar que os jovens brasileiros que estão matriculads nos colégios ou nas universidades japoneses, que são pagos, também estariam nas dificuldades, sendo obrigados a abandonarem os estudos. Para não perder as potencialidades dessas crianças, medidas urgentes em termos de educação devem ser tomadas nos dois países. 


\section{Tabela Cronológica}

1853 Americanos intervêm no Japão, que é obrigado a abrir seus portos ao ocidente.

1868 Restauração Meiji.

1871 Abolição do feudalismo no Japão.

1874 Início da corrente imigratória italiana para o Brasil.

1888 Promulgação da Lei Áurea, que põe fim à escravidão no Brasil.

1889 Proclamação da República no Brasil.

1894 Política do "café-com-leite" (1894-1930)

Primeira Guerra Sino-Japonesa.

1904 Início da Guerra Russo-Japonesa.

1906 Convênio de Taubaté

1908 A chegada da imigração japonesa.

1910 O Japão anexa a Coreia.

1914 Início da Primeira Guerra Mundial.

1917 Realiza-se a segunda valorização do café.

1918 Geada mata cafezais.

Fim da Primeira Guerra Mundial.

Revolta do Arroz.

1921 Início da terceira operação valorizadora do café

Cessação de subsídio pelo governo estadual paulista 
1923 Grande Terremoto de de Kantô (no Japão).

1925 Criação do Instituto do Café do Estado de São Paulo.

Início do oferecimento de subisídio para imigrantes japoneses pelo governo japonês.

1927 Fundação da Bratac (Sociedade Colonizadora do Brasil).

1929 Colapso na Bolsa de Nova York provoca a grande crise econômica internacional.

Expansão dos migrantes japoneses para os Estados de Amazonas, Paraná, Minas Gerais, etc.

1930 Estado Novo (1930-1945)

Getúlio Vargas é nomeado chefe do governo provisório.

Início das medidas restritivas para imigrantes estrangeiros por Getúlio Vargas.

1931 Cria-se o Ministério do Trabalho, Indústria e Comércio.

Começa a promulgação de leis sociais.

Criado o Conselho Nacional do Café.

Começa o programa de defesa do café através da destruição física de estoques.

1933 Criados o Departamento Nacional do Café e o Instituto do Açúcar e do Álcool.

1934 Introdução de regimes de cotas para imigrantes no Brasil

1937 Eclode da Segunda Guerra Sino-Japonesa.

1937-1939 Restrição aos órgãos de impresa de língua estrangeira e ao ensino de língua estrangeira

1939 Início da Segunda Guerra Mundial. 
1941 Os japoneses bombardeiam Pearl Harbour. Os Estados Unidos entram na guerra.

Cessação da imigração japonesa para o Brasil antes da guerra.

1945 A República populista (1945-1964)

Vargas renuncia sob pressão militar.

Fim da Segunda Guerra Mundial.

Derrota do Japão e ocupação pelos EUA (1945-1952)

1950 Eleições Presidenciais. Vitória de Getúlio Vargas.

Guerra da Coreia.

1952 Decreto impõe limite de $10 \%$ para a remessa de lucros ao exterior.

Retomada da imigração japonesa pós-guerra para o Brasil (1952-1973)

1953 Baixada a Instrução nº 70 da Superintendência da Moeda e Crédito (Sumoc), que visa estimular as exportações e favorecer as importações de bens essenciais ao desenvolvimento econômico.

Criação da Petrobras.

1954 Decreto de Vargas impõe novas restrições ao capital estrangeiro.

Vargas propõe projeto de criação da Eletrobrás.

Vargas se suicida em 24 de agosto.

1955 Instrução n⿳o 113 da Sumoc favorece os investidores estrangeiros.

1956 Jucelino Kubitschek é eleito presidente da República.

Kubitschek inicia a aplicação de seu plano de metas, com o slogan "Cinquenta anos em cinco".

1957 Início da construção de Brasília.

1959 Juscelino Kubitschek declara o rompimento do Brasil com o Fundo 
Monetário Internacional.

1960 Eleições Presidenciais. Vitória de Jânio Quadros para presidência e João Goulart para a vice-presidência.

Jucelino Kubitschek inaugura Brasília.

1961 O presidente eleito Jânio Quadros toma posse em 31 de janeiro e renuncia em 25 de agosto. Goulart toma posse.

É promulgada a Lei de Diretrizes e Bases da Educação.

1962 O Congresso aprova lei que restringe a remessa de lucros para o exterior.

1963 Plebiscito põe fim ao parlamentarismo.

1964 O Golpe Militar.

Em 31 de março é deflagrado um golpe político-militar que afasta João Goulart.

O Ato Institucional $\mathrm{n}^{\mathrm{o}} 1$ suspende os direitos políticos de centenas de pessoas.

1965 Promulgado o AI-2, que extingue os partidos políticos existentes.

Reforma monetária institui o Cruzeiro Novo.

1968 AI-5 cassa os mandatos de diversos parlamentares.

1970 Intensifica-se a oposição ao governo, com guerrilhas na cidade e no campo. A par do endurecimento do regime, com censura, prisões e torturas, o governo militar desenvolve grandes projetos de integração nacional como a Transamazônica, o INCRA e o Mobral.

1972 Inaugurada a Transamazônica, em meio a críticas pela devastação do ambiente e pela invasão de terras indígenas.

1973 O general Ernesto Geisel é indicado para suceder o general Médici. 
Choque do Petróleo.

1977 Intensifica-se o movimento da sociedade civil em favor da recuperação dos direitos democráticos.

1978 Geisel inicia um processo de distensão gradual. Fim do AI-5.

1979 Figueiredo assume a presidência.

Aprovada a Lei de Anistia.

Restabelecida a pluraridade partidária, com a extinção da Arena e do MDB.

1980 A crise econômica se agrava; multiplicam-se as greves e os movimentos de protesto.

1982 Eleições legislativas e para governadores e prefeitos. Vitória da oposição em Estados como São Paulo, Minas Gerais, Rio de Janeiro e Paraná.

Crise da dívida externa. O Brasil se reconhece sem condições de saldar os compromissos da dívida e recorre ao FMI.

1984 O país se mobiliza reivindicando eleições diretas. Emenda com este objetivo é votada e rejeitada pelo Congresso.

1985 O Colégio Eleitoral elege Tancredo Neves, um novo presidente civil e oposicionista. Ele morre antes da posse, e a presidência é assumida por seu vice, José Sarney.

1986 Decretado o Plano Cruzado, destinado a conter a inflação e estabilizar a economia

Eleições para compor uma Assembleia Constituinte: o PMDB obtém maioria expressiva, além de eleger 22 governadores.

Prosperidade econômica no Japão (“Economia de Bolha”, 1986-1991).

1987 Instala-se a Assembleia Constituinte, sob a presidência de Ulysses Guimarães. 
A crise econômica se aprofunda: a inflação não é controlada.

1988 Promulgada a nova Constituição.

Cresce a violência na cidade e no campo.

1989 Fernando Collor de Mello é o primeiro presidente eleito pelo voto direto desde 1960.

Um surto de violência assola principalmente as grandes cidades.

1990 O Plano Collor. Collor lança um plano econômico revolucionário, como estratégia de combate à inflação: cria uma nova moeda e congela depósitos bancários por dezoito meses.

Assinado tratado de livre comércio com a Argentina.

A reforma da LCI (Lei de Controle de Imigração) japonesa.

1991 Retomada da escalada inflacionária. O governo não obtém o apoio do Congresso, e a crise econômica se aprofunda.

Novo conjunto de medidas de impacto busca corrigir a política econômica.

A violência se dissemina.

Fim da "Economia de Bolha" e início da recessão econômica

1992 Denúncias de corrupção provocam o impeachment de Collor. Seu vice, Itamar Franco, assume a presidência.

1993 Plebiscito popular opta por Presidencialismo Republicano como sistema de governo.

Nova reforma econômica cria o Cruzeiro Real. Sucedem-se os ministros da Fazenda, em tentativas de debelar a inflação e sanar a economia.

Violência crescente.

1998 Momento mais crítico da economia japonesa após o término da "Economia 
de Bolha"

1999 Melhoria temporária da economia japonesa devido a boom americano incentivado pela TI

2002 Início do processo da recuperação prolongada da economia japonesa

2008 Crise financeira mundial

Observação: Tabela cronológica que abarca desde o final da era Edo do Japão até os dias atuais. As partes coloridas se referem aos acontecimentos da História do Japão e do mundo; as em preto, aos acontecimentos da História do Brasil. 


\section{REFERÊNCIAS BIBLIOGRÁFICAS}

BÖHNING, Wolf Rudiger. Formas e funções de relacionamentos internacionais no campo da migração para fins de emprego In NINOMIYA, M. Dekassegui: palestras e exposições do Simpósio Sobre o Fenômeno Chamado Dekassegui. São Paulo: Sociedade Brasileira de Cultura Japonesa, 1992.

CARDOSO, Ruth Corrêa Leite. Estrutura familiar e mobilidade social: estudo dos japoneses no Estado de São Paulo. NINOMIYA, Masato (org.). São Paulo. Kaleidos-Primus. 1998. Tese (doutorado) - Universidade de São Paulo, 1972.

CENTRO DE ESTUDOS NIPO-BRASILEIROS (abreviado como CENB no texto). Pesquisa da população de descendentes de japoneses residentes no Brasil 1987-1988. São Paulo: Centro de estudos nipo-brasileiros, 1990.

. Nikkei shakai jittai cho-sa ho-kokusho ("Relatório da pesquisa da realidade da colônia japonesa”). São Paulo: Centro de estudos nipo-brasileiros, 2002.

COMISSÃO DE RECENSEAMENTO DA COLÔNIA JAPONESA. The Japanese immigrants in Brazil. Tóquio: University of Tokyo Press, 1964.

CORRÊA COSTA, João Pedro. De decasségui a emigrante. Brasília: Fundação Alexandre de Gusmão, 2007.

DE VASCONCELlOS, Marco Antonio Sandoval; GREMAUD, Amaury Patrick; JÚNIOR, Rudinei Toneto. Economia Brasileira Comtemporânea. São Paulo: Editora Atlas, 1999.

DEL PIORE, Mary; DAS NEVES, Maria de Fatima; ALAMBERT, Francisco. Documentos de história do Brasil: de Cabral aos anos 90. São Paulo: Scipione, 1997.

DUANY, Jorge. Mobile livelihoods: The sociocultural practices of circular migrants between Puerto Rico and the United States, In International Migration Review, Nova York: Center for Migration Studies of New York, v.36(2), Summer 2002, p. 355-388.

FAUSTO, Boris. História do Brasil. São Paulo: EDUSP, 2007.

FERREIRA, Aurélio Buarque de Holanda. Novo dicionário da língua portuguesa. São Paulo: 
Editora Nova Fronteira, 2007.

FERREIRA, Ricardo Hirata. O confronto dos lugares no migrante dekassegui. Dissertação (Mestrado) - Instituto de Geociências e Ciências Exatas, Universidade Estadual Paulista, São Paulo, 2001.

Migrações Internacionais: Brasil ou Japão - o movimento de inserção do dekassegui no espaço geográfico pelo consumo. Tese (Doutorado) - Faculdade de Filosofia, Letras e Ciências Humanas da Universidade de São Paulo, São Paulo, 2007.

HADDOCK LOBO, R. História Econômica e Administrativa do Brasil. São Paulo: Instituto Progresso Editorial S.A., 1949.

HALL, Stuart. Identidade cultural e diáspora. Revista do Patrimônio Histórico e Artístico Nacional, $\mathrm{n}^{\mathrm{0}} 24,1996, \mathrm{p} .68-75$.

HIRABAYASHI, Lane Ryo (ed.) New Worlds, New Lives: Globalization and People of Japanese Descent in the Americas and from Latin American in Japan. Palo Alto: Stanford University Press. 2002.

HIGUCHI, Naoto. Brazilian Migration to Japan: Trends Modalities and Impact. Mexico City: Relatório para Expert Group Meeting on International Migration and Development in Latin America and the Caribbean. United Nations Secretariat. UN/POP/EGM-MIG/2005/11. 2006.

HITOMI, Haruo e ARAKAWA, Jun. Nihonshi B Yôgoshû (“Glossário da história japonesa”). Tóquio: Yamakawa shuppan (“Editora Yamakawa”), 1996.

ISHI, Angelo. Gaikokujin Shu-ju-chi wo iku ("Percorrendo regiões com a contenctração de estrangeiros"), In Cĥ̂-ô-kô-ron. Tóquio: Chû-ô-kô-ron sha ("Editora Chû-ô-kô-ron"), v.116, fasc.10, p. 171-177, 2001a.

. IT jidai no imin to imin kenkyû ("Migrações e pesquisas das migrações na era da TI”), In Imin kenkyû nenpô (“Anuário da pesquisa da migração”). Tóquio: v.7, p. 163-176, 2001b.

ISHIGAKI, Yasuji. "Discurso de abertura dos trabalhos do simpósio sobre o fenômeno chamado dekassegui” In NINOMIYA, M. Dekassegui: palestras e exposições do Simpósio Sobre o Fenômeno Chamado Dekassegui. São Paulo: Sociedade Brasileira de Cultura Japonesa, 1992.

IYOTANI, Toshio. Gurôbaruka to teijûgaikokujin no sanseiken ("Globalização e direito de 
voto de estrangeiros residentes no Japão") In MIYAJIMA, Takashi (ed.). Gaikokujin shimin to seiji sanka (“Cidadãos estrangeiros e participação política”). Tóquio: Yu-shindo, 2000.

KAJITA, Takamichi. Gyôshuku sareta imin saikuru: nikkeijin ni miru "dekasegi” no hennyô (“Um ciclo compactado de migração - a mudança dos decasséguis dos nikkeis"). Revista Hikaku Bunmei, v.14, p. 51-65, 1998.

KAJITA, Takamichi et al. Kao no mieai teijûka - nikkei burajirujin to kokka sijô imin nettowâku ("Invisible Residents - Japanese Brazilians vis-à-vis the State, the Market and the Imigrant Network"). Nagoya: Nagoya Daigaku Shuppankai, 2005a.

KAJITA, Takamichi et al. Shin Kokusai Shakaigaku ("Transnational Sociology”). Nagoya: Nagoya Daigaku Shuppankai, 2005b.

KAWAMURA, Lili Katsuko. Estratégias de sobrevivência: Trabalhadores Brasileiros no Japão ou Trabalhadores Brasileiros no Japão: Estratégias de Sobrevivência. São Paulo. 1998.

. Para onde vão os brasileiros?: imigrantes brasileiros no Japão. $2^{\text {a }}$ ed. rev. Campinas, São Paulo: UNICAMP, 2003a.

Redes sociales y culturales de migrantes brasilenõs en la ruta Brasil-Japón: Movimento y permanencia. In YAMADA, Mutsuo (org.). Emigración Latinoamericana: Comparación Interregional entre América del Norte, Europa y Japón. JCAS Symposium Series 19. Osaka, Japão: The Japan Center for Area Studies (JCAS). National Museum of Ethnology, 2003b.

KITAGAWA, Toyoie. Uma nova etapa na questão dos trabalhadores nikkey. In NINOMIYA, M. Dekassegui: palestras e exposições do Simpósio Sobre o Fenômeno Chamado Dekassegui. São Paulo: Sociedade Brasileira de Cultura Japonesa, 1992.

KOIDO, Akihiro. Kokusai Imin no Shakaigaku ("Sociologia das imigrações internacionais") In KAJITA, T. Shin Kokusai Shakaigaku. Nagoya: Nagoya Daigaku Shuppankai, 2005b.

KONNO, Toshihiko. Imin-shi (“História da Emigração"). Tóquio: Shinsen sha, 1984.

LITVIN, Aaron. A adaptação social e econômica dos migrantes brasileiros no Japão. Dissertação (Mestrado) - Departamento de Sociologia da Faculdade de Filosofia, Letras e Ciências Humanas da Universidade de São Paulo, SP, 2007.

MIYOSHI, Takefumi. Manual da lei de imigração japonesa: conhecimentos básicos sobre a 
entrada e a permanência no Japão. Tradução de Masato Ninomiya. São Paulo: Editora Estação Liberdade, 1993.

MORI, Edson. The Japanese-Brazilian Dekasegi Phenomenon: An Economic Perspective. In HIRABAYASHI, L. New Worlds, New Lives: Globalization and People of Japanese Descent in the Americas and from Latin American in Japan. Palo Alto: Stanford University Press. 2002.

MORI, Koichi. Transição dos decasséguis provenientes do Brasil e considerações sobre alguns dos problemas. In Dekassegui: Palestras e exposições do Simpósio Sobre o Fenômeno Chamado Dekassegui. NINOMIYA, Masato (org.). São Paulo: Estação Liberdade. Sociedade Brasileira de Cultura Japonesa, 1992.

MORI, Koichi. Kanryû gata ijû to shiteno dekasegi (o decasségui como transmigração). In HIROMASA, Mori. Kokusai rôdôryoku idô no gurôbaruka (a globalização de movimentos internacionais de mão de obra). Hôsei daigaku hikaku keizai kenkyûjo kokusai. Tóquio: Instituto das Economias Comparadas da Universidade de Hôsei, 2000.

NARIAI, Osamu. History of the modern Japanese economy. Tóquio: Foreign Press Center Japan, 1999.

NINOMIYA, Masato (org.). Dekassegui: Palestras e exposições do Simpósio Sobre o Fenômeno Chamado Dekassegui. São Paulo: Estação Liberdade/Sociedade Brasileira de Cultura Japonesa, 1992.

NINOMIYA, Masato. The Dekasegi Phenomenon and the Education of Japanese Brazilians Children in Japanese Schoolds. In HIRABAYASHI, L. New Worlds, New Lives: Globalization and People of Japanese Descent in the Americas and from Latin American in Japan. Palo Alto: Stanford University Press. 2002.

NINOMIYA, Masato (org.). Anais do simpósio internacional do $10^{\circ}$ aniversário do CIATE. São Paulo: Toppn-Press Ltda., 2003.

NOGUEIRA, Arlinda Rocha. Imigração japonesa na história contemporânea do Brasil. São Paulo: Centro de Estudos Nipo-brasileiros/Massao Ohno editor, 1984.

REIS, Maria Edileuza Fontenele. Brasileiros no Japão - O Elo Humano das Relações Bilaterais. $2^{a}$ ed., São Paulo: Kaleidus Primus, 2002.

REIS, Rosana Rocha. Sales Teresa (org.). Cenas do Brasil migrante. São Paulo: Boitempo 
editorial, 1999.

ROCHA-TRINIDADE, Maria Beatriz. Sociologia das Migrações. Lisboa: Universidade Aberta, 1995.

SASAJIMA, Yoshio. Labor in Japan. Tóquio: Foreign Press Center Japan, 2003.

SASAKI, Elisa Massae. O jogo da diferença: a experiência identitária no movimento dekassegui. Dissertação (Mestrado) - Departamento de Sociologia, do Instituto de Filosofia e Ciências Humanas, da Universidade Estadual de Campinas, Campinas, SP, 1998.

Movimento dekassegui: a experiência migratória e identitária dos brasileiros descendentes de japoneses no Japão. In REIS, Rosana Rocha et al. Cenas do Brasil migrante. São Paulo: Boitempo editorial, 1999.

SCHWARTZ, Gilson. Aspectos Econômicos do Fenômeno Dekassegui. In MASATO, Ninomiya (org.). Dekassegui: Palestras e exposições do Simpósio Sobre o Fenômeno Chamado Dekassegui. São Paulo: Estação Liberdade/Sociedade Brasileira de Cultura Japonesa, 1992.

SOCIEDADE BRASILEIRA DE CULTURA JAPONESA (abreviada como SBCJ no texto). Uma epopéia moderna: 80 anos da imigração japonesa no Brasil. São Paulo: HUCITEC, 1992.

TANNO, Kiyoto. Ekkyô suru koyô shisutemu to gaikokujin rôdôsha ("Transnational Employment System and Migrant Workers in Japan”). Tóquio: Tôkyô Daigaku Shuppankai (Editora da Universidade de Tóquio), 2007.

YAMAGUCHI, Ana Eliza. Zainichi Burajirujin no Ripîtâ Gata Idô ("Movimentos repetitivos dos brasileiros residentes no Japão"). Kokusaiimin no Shin dôkô to gaikokujin seisaku no kadai (“A nova tendência de imigração internacional e questão de políticas imigrantes"). Relatório da pesquisa consignado pelo Ministério de Justiça. Tóquio: 2001.

YAMAZAKI, Hiroaki (ed.). Nihon keiei shi no kiso chishiki ("Conhecimentos básicos sobre a história da administração japonesa”). Tóquio: Yûhikaku Books, 2004. 


\section{REFERÊNCIA DE DOMÍNIO ELETRÓNICO CONSULTADO}

http://www.pref.shizuoka.jp/kenmin/km-140/jittaichousa.html

Pesquisa da província de Shizuoka realizada pelos seguintes pesquisadores: Shiguehiro Ikegami (Universidade de Cultura e Arte da Província de Shizuoka); Eunice Akemi Ishikawa (Universidade de Cultura e Arte da Província de Shizuoka); Hirohisa Takenoshita (Universidade de Shizuoka); e Yoshimi Chitose (National Institute of Population and Social Security Research do Japão). 